\title{
Republic of Tajikistan: Fifth Review Under the Poverty Reduction and Growth Facility and Request for Waiver of Performance Criterion-Staff Report; and Press Release on the Executive Board Consideration
}

In the context of the fifth review under the Poverty Reduction and Growth Facility and request for a waiver of a performance criterion, the following documents have been released and are included in this package:

- $\quad$ the staff report for the Fifth Review Under the Poverty Reduction and Growth Facility and Request for Waiver of Performance Criterion, prepared by a staff team of the IMF, following discussions that ended on April 29, 2005, with the officials of the Republic of Tajikistan on economic developments and policies. Based on information available at the time of these discussions, the staff report was completed on July 8, 2005. The views expressed in the staff report are those of the staff team and do not necessarily reflect the views of the Executive Board of the IMF.

- $\quad$ a staff supplement of July 15, 2005 updating information on recent developments.

- a Press Release summarizing the view of the Executive Board as expressed during its consideration of the staff report that completed the review and request.

The documents listed below have been separately released.

Letter of Intent sent to the IMF by the authorities of the Republic of Tajikistan*

Supplementary Memorandum of Economic and Financial Policies by the authorities of the Republic of Tajikistan*

*May also be included in Staff Report

The policy of publication of staff reports and other documents allows for the deletion of market-sensitive information.

To assist the IMF in evaluating the publication policy, reader comments are invited and may be sent by e-mail to publicationpolicy@imf.org.

Copies of this report are available to the public from

International Monetary Fund • Publication Services

$70019^{\text {th }}$ Street, N.W. • Washington, D.C. 20431

Telephone: (202) 623-7430 • Telefax: (202) 623-7201

E-mail: publications@imf.org • Internet: http://www.imf.org

Price: $\$ 15.00$ a copy

\section{International Monetary Fund Washington, D.C.}





\title{
INTERNATIONAL MONETARY FUND
}

\author{
REPUBLIC OF TAJIKISTAN
}

\section{Fifth Review Under the Poverty Reduction and Growth Facility and Request for Waiver of Performance Criterion}

\author{
Prepared by Middle East and Central Asia Department \\ (In consultation with other departments) \\ Approved by Juan Carlos Di Tata and Mark Plant
}

July 8, 2005

- Discussions on the fifth review under the Poverty Reduction and Growth Facility (PRGF) arrangement took place in Dushanbe from April 19-29, 2005. A PRGF arrangement in an amount equivalent to SDR 65 million (75 percent of quota) was approved on December 11, 2002. As of end-May 2005, Tajikistan's outstanding use of Fund resources was SDR 87.8 million (101.0 percent of quota).

- The staff team comprised Messrs. Winglee (head), Zytek, and Matovu (all MCD), Ms. Brixiova (PDR), and Mr. Alexander (STA). Mr. Khawaja, the Fund's resident representative in Dushanbe, assisted the mission. Mr. Nuraliev (OED) participated in the policy discussions.

- $\quad$ The mission met with President Rakhmonov, Prime Minister Akilov, State Economic Advisor Kholboboev, Minister of Finance Nadjmiddinov, Minister of Economy and Trade Soliev, National Bank Chairman Alimardonov, other senior officials, members of parliament, donors, NGOs, and the media.

- In the attached Letter of Intent and Supplementary Memorandum of Economic and Financial Policies (MEFP) (Attachments I and II), the authorities report on the implementation of the program, set out their policies for the remainder of the third year, and request the completion of the fifth review under the PRGF arrangement and the extension of the arrangement by two months.

- Tajikistan accepted the obligations under Article VIII, Sections 2, 3, and 4 in December 2004 and maintains an exchange system that is free of restrictions on the making of payments and transfers for current international transactions. 


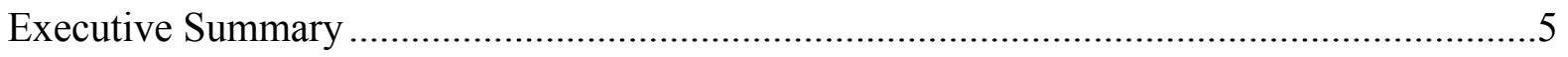

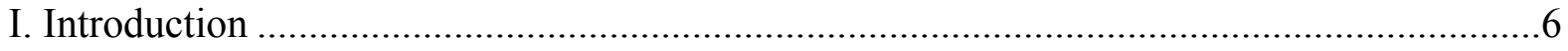

II. Recent Developments and Performance Under the Program.........................................6

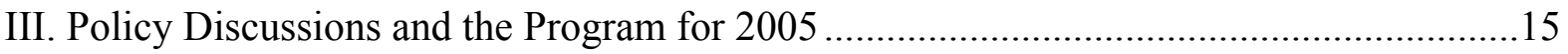

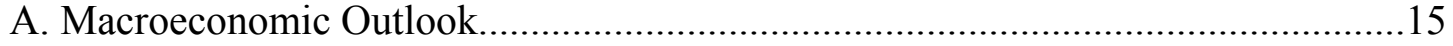

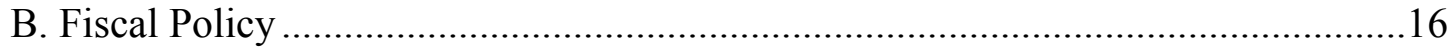

C. Monetary and External Policies ..................................................................... 18

D. Structural Reforms and Poverty Reduction Strategy .......................................18

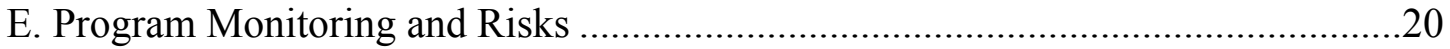

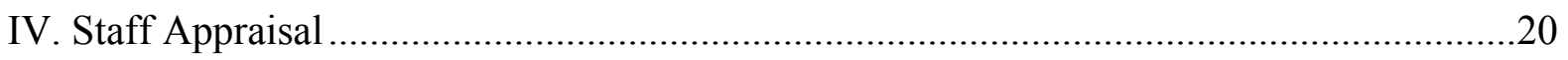

Boxes

1. Performance Under the Third Annual Program Under the PRGF

Arrangement, January-June 2005 ................................................................ 7

2. Developments in Financial System Credit................................................................ 11

3. Is Tajikistan's Trade Deficit "Too High"? .................................................................13

Tables

1. Selected Macroeconomic Indicators, 2001-05 .......................................................22

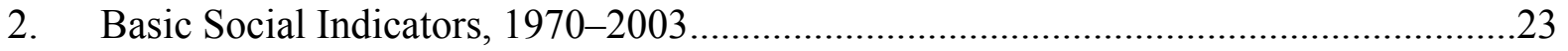

3. General Government Operations, 2003-05 (in millions of somoni) ...........................24

4. General Government Operations, 2003-05 (in percent of GDP) .................................25

5. General Government Operations by Functional Classification, 2003-05 ....................26

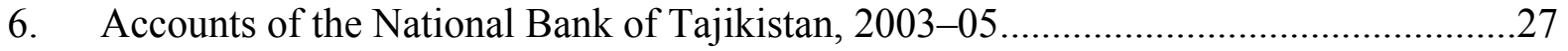

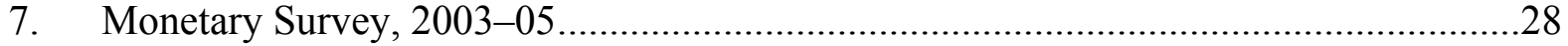

8. Balance of Payments, 2003-05 .............................................................................29

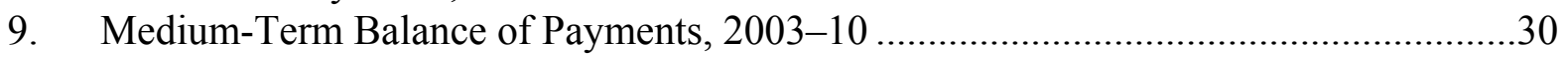

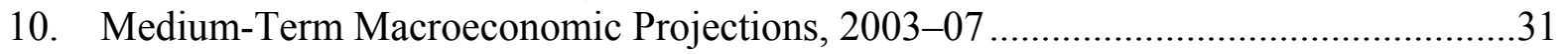

11. Fund Position During the Period of the PRGF Arrangement,

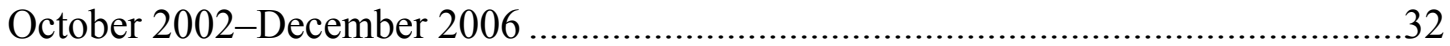

12. Reviews and Disbursements Under the Three-Year PRGF Arrangement, 2002-05 ......33

13. Millennium Development Goals, 1990-2015 ............................................................34

Appendices

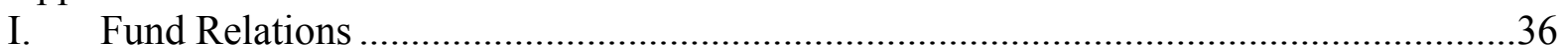

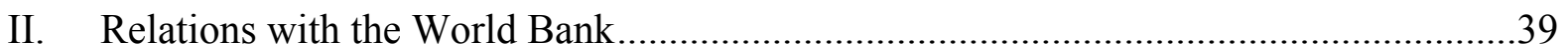

III. Relations with the Asian Development Bank .........................................................45

IV. Selected Reform Areas and Cooperation with Development Partners, 2003-05 ..........49

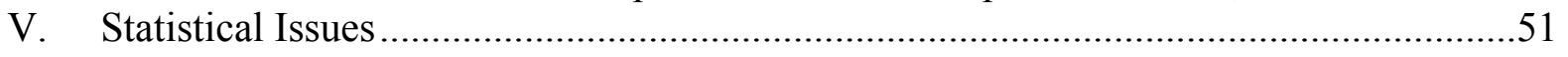


Attachments

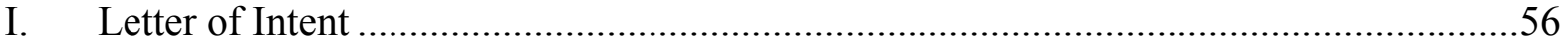

II. Supplementary Memorandum of Economic and Financial Policies for the Period April 1, 2005 to December 31, 2005. 


\section{LIST OF ACRONYMS}

\begin{tabular}{|c|c|}
\hline $\mathrm{ADB}$ & Asian Development Bank \\
\hline APR & Annual Progress Report on PRSP Implementation \\
\hline CIS & Commonwealth of Independent States \\
\hline CPI & Consumer Price Index \\
\hline DSA & Debt Sustainability Analysis \\
\hline EBRD & European Bank for Reconstruction and Development \\
\hline FAD & IMF Fiscal Affairs Department \\
\hline FDI & Foreign Direct Investment \\
\hline GDP & Gross Domestic Product \\
\hline IDA & International Development Association \\
\hline IFC & International Finance Corporation \\
\hline LEG & IMF Legal Department \\
\hline LTI & Large Taxpayer Inspectorate \\
\hline MDG & Millennium Development Goals \\
\hline MEFP & Memorandum of Economic and Financial Policies \\
\hline MOF & Ministry of Finance \\
\hline MSRD & Ministry of State Revenues and Duties \\
\hline NBT & National Bank of Tajikistan \\
\hline NFA & Net Foreign Assets \\
\hline NIR & Net International Reserves \\
\hline NPL & Nonperforming Loan \\
\hline $\mathrm{PBC}$ & Policy Based Credit (World Bank) \\
\hline PIP & Public Investment Program \\
\hline PRGF & Poverty Reduction and Growth Facility \\
\hline PRSC & Poverty Reduction Support Credit \\
\hline PRSP & Poverty Reduction Strategy Paper \\
\hline ROSC & Report on Standards and Codes \\
\hline RUSAL & Global aluminum producer based in Russia \\
\hline SAC & Structural Adjustment Credit (World Bank) \\
\hline SEDP & Socio Economic Development Plan \\
\hline SDDS & Special Data Dissemination Standard \\
\hline SME & Small- and Medium-Size Enterprises \\
\hline SOE & State-Owned Enterprises \\
\hline STA & IMF Statistics Department \\
\hline TadAZ & Tajik Aluminum Plant \\
\hline USAID & US Agency for International Development \\
\hline VAT & Value Added Tax \\
\hline WTO & World Trade Organization \\
\hline
\end{tabular}




\section{EXECUTIVE SUMMARY}

The focus of the discussions for the fifth review was on sustaining the implementation of the policies envisaged in the third annual program under the PRGF arrangement, which remain broadly appropriate.

The macroeconomic outcome in the first quarter of 2005 was satisfactory, but the deteriorating external environment will make it harder to achieve some of the program's original targets. The target for real GDP growth of 8 percent in 2005 remains achievable, but inflation is now projected at 7 percent by year's end ( 6 percent in the original program) on account of some recent exchange rate depreciation. Weaker cotton and aluminum prices are dampening export revenues, and the external current account deficit is expected to widen to 5 percent of GDP in 2005, notwithstanding higher than envisaged remittances from abroad.

Expenditure delays and strong nontax revenues resulted in a significant fiscal surplus in the first quarter of 2005. Since then, spending has picked up, although it remains below the cumulative program level. Prudent monetary policy and the fiscal surplus helped achieve the monetary program targets. A short delay in the disbursement of a program grant, however, resulted in the nonobservance of the March performance criterion on net international reserves.

The fiscal outlook for the remainder of 2005 looks less favorable owing to lower than projected commodity prices. With administrative reforms and higher imports, however, additional revenue from the VAT should be able to offset the decline in commodity-based taxes. Expenditures will need to be monitored closely to avoid exceeding budget allocations.

Monetary policy will need to remain cautious; the reserve money target of 10 percent is being retained. The introduction of marketable government securities will be an important contribution to broadening the range of available monetary instruments.

Progress in implementing structural conditionality has been slow, but with some adaptations, most of the envisaged reforms are expected to be brought to completion within the third annual program. Regarding the structural benchmarks for March 2005, a mechanism to ensure TadAZ's electricity and tax payments was implemented, but the rationalization of the government's economic planning functions is still in process. The authorities are making efforts to ensure that the program's structural benchmarks for June and September 2005 are met, including the development of a database on private external debt, debt recoveries by the NBT, and the establishment of a cash management unit. 


\section{INTRODUCTION}

1. On March 18, 2005, the Executive Board completed the fourth review of Tajikistan's three-year Poverty Reduction and Growth Facility (PRGF) Arrangement. At that time, Directors commended the authorities for the considerable progress made in 2004 in strengthening Tajikistan's economic performance and indicated that sound macroeconomic policies and political stability had contributed to strong growth, a marked decline in inflation, and a reduction in poverty. Directors noted, however, that sustaining rapid growth required a stronger commitment to structural reform, especially in the areas of revenue administration, public administration, the banking system, and private sector development.

2. Based on the satisfactory performance under the program, the authorities are requesting the completion of the fifth review (Box 1). All but one quantitative performance criteria for end-March 2005 and all the program's structural performance criteria were observed. The end-March 2005 performance criterion on net international reserves (NIR) was not observed because of a short delay in the disbursement of a program grant; a waiver has been requested for this temporary deviation. One of the two structural benchmarks for March 2005 was implemented, the other is in process, and the June benchmarks are expected to be substantially completed by early July.

\section{Recent Developments and Performance Under the Program}

3. Macroeconomic conditions were relatively favorable in Q1 2005 but have weakened somewhat recently. Real GDP growth slowed to 7.8 percent in Q1 2005, from 9.1 percent in the same period of 2004, but is still in line with the growth projection of 8 percent for the year as a whole, which is above the average for CIS countries. Output growth slowed in all main categories, especially aluminum (winter production was reduced to conserve power) and the services sector. While some preliminary work on the large Sangtuda I hydropower project is underway, large-scale construction has not yet started, and foreign investment in other sectors remains low. Strong growth in household incomes from wages and remittances has kept up consumption, notwithstanding that farm incomes have been hard hit by the increase in fuel prices and low cotton prices.

Growth and Inflation Performance in Selected Countries, 1998-2005

(In percent)

\begin{tabular}{lrrrrr}
\hline & \multicolumn{2}{c}{ Real GDP Growth } & & \multicolumn{2}{c}{ Average Inflation } \\
\cline { 2 - 3 } \cline { 5 - 6 } & $\begin{array}{r}\text { Annual average } \\
(1998-2004)\end{array}$ & 2005 Q1/2004Q1 & & $\begin{array}{c}\text { Annual average } \\
(1998-2004)\end{array}$ & 2005 Q1/2004Q1 \\
\hline Armenia & 9.0 & 7.8 & 2.9 & 4.4 \\
Azerbaijan & 10.1 & 10.8 & -0.2 & 13.1 \\
Georgia & 5.3 & $\ldots$ & 7.0 & 9.4 \\
Kyrgyz Republic & 4.3 & 2.0 & 12.9 & 3.0 \\
Moldova & 0.7 & $\ldots$ & & 17.4 & 13.0 \\
Tajikistan & 8.3 & 7.8 & 26.2 & 5.7 \\
Uzbekistan & 4.9 & $\ldots$ & 32.3 & 13.0 \\
\hline
\end{tabular}

Source: CIS database. 


\section{Box 1. Tajikistan: Performance Under the Third Annual Program Under the PRGF Arrangement, January-June 2005}

Quantitative performance criteria (March 2005)

Ceiling on net domestic assets of the NBT.

Ceiling on net credit of the banking system to general government.

Ceiling on the cumulative overall fiscal balance of the general government.

Ceiling on general government wage, and nonworking pensioners' pension arrears

Floor on tax collection of the ministry of state revenues and duties.

Floor on total net international reserves.

Ceiling on the contracting or guaranteeing of short-, medium-, and long-term nonconcessional external debt.

New external payments arrears.

\section{Indicative targets (March 2005)}

Ceiling on reserve money.

New arrears of budget entities and key state-owned enterprises to utility companies.

\section{Continuous structural performance criteria}

Prohibit the NBT from issuing directed credits.

Prohibit the NBT from making expenditures not related to its core business.

Implement quarterly adjustments of all utility tariffs, equivalent to the depreciation in the nominal exchange rate in the previous quarter.

\section{Structural benchmarks}

For End-March 2005

Implement the mechanism to ensure the immediate transfer to the Treasury by Barki Tajik of the tax portion of TADAZ's payments to Barki Tajik.

As part of streamlining economic ministries, cease publication of detailed production targets disaggregated below the national level. Integrate various bodies preparing strategic plans and coordinating aid.

\section{For End-June 2005}

Reduce NBT's claims on the private sector by SM 10 million from October 2004 to June 2005 through collateral sales or other loan recoveries.

Remove the regulatory limits on foreign capital in the banking system and the requirement for a Tajik citizen to head commercial banks in the Banking Law.

Expand the register of the Large Taxpayer Inspectorate (LTI) to cover at least 60 percent of total tax collections.

Develop and continuously update a database at the NBT for monitoring private sector external debt (starting with cotton sector debt).
Observed

Observed

Observed

Observed

Observed

Not observed

Observed

Observed

Observed

Not observed

Observed

Observed

Observed

Observed in April

Detailed targets stopped, integration of plans starting July for completion by September

SM 4 million collected by early June, remainder in process

Amendments to be submitted to parliament by early July

Coverage being increased

Database started with main lenders 


\section{Box 1. Tajikistan: Performance Under the PRGF Arrangement (December-March 2005)}
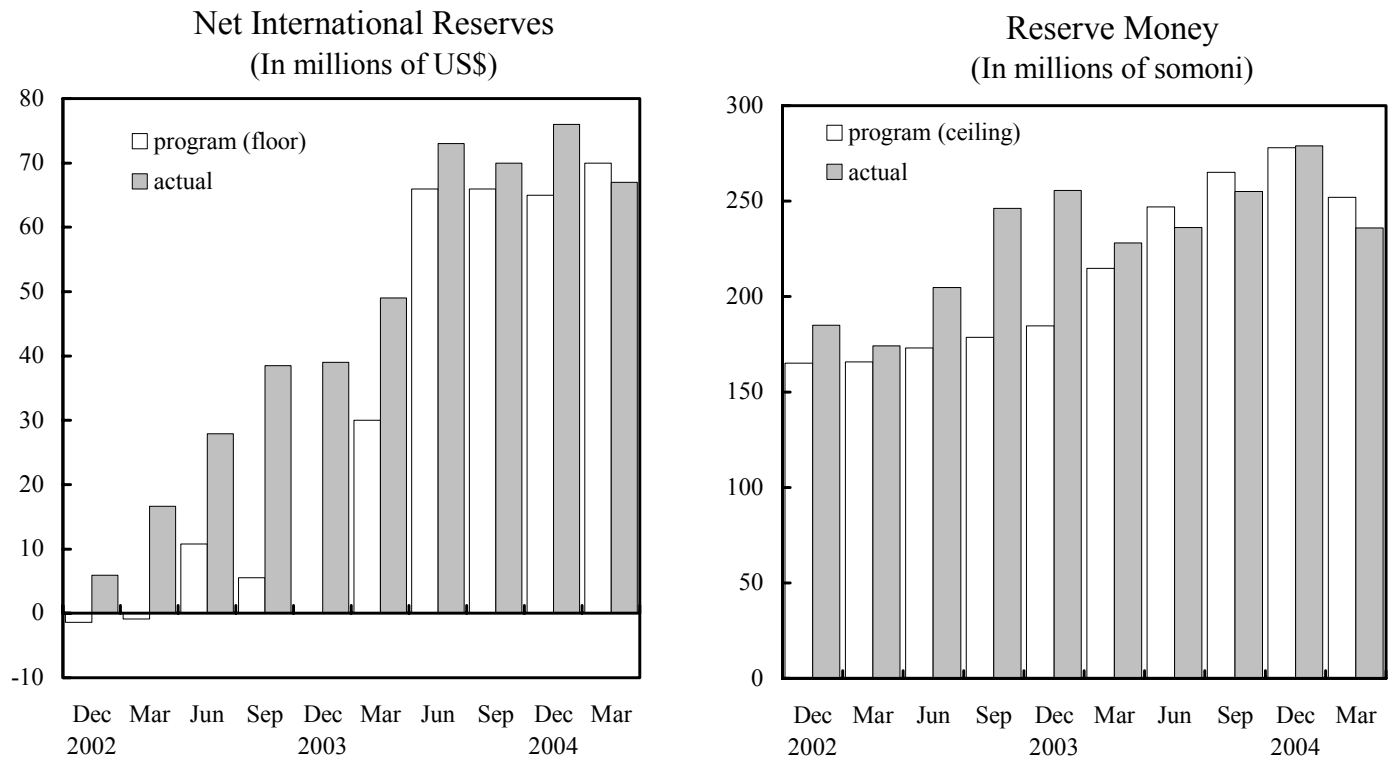

Overall Fiscal Balance 1/2/

(In millions of somoni)

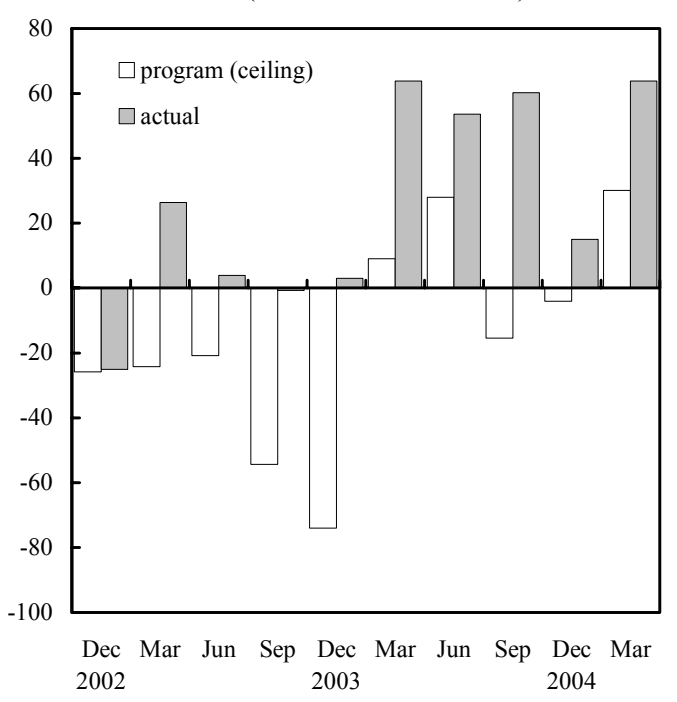

Tax Revenue 2/

(In millions of somoni)

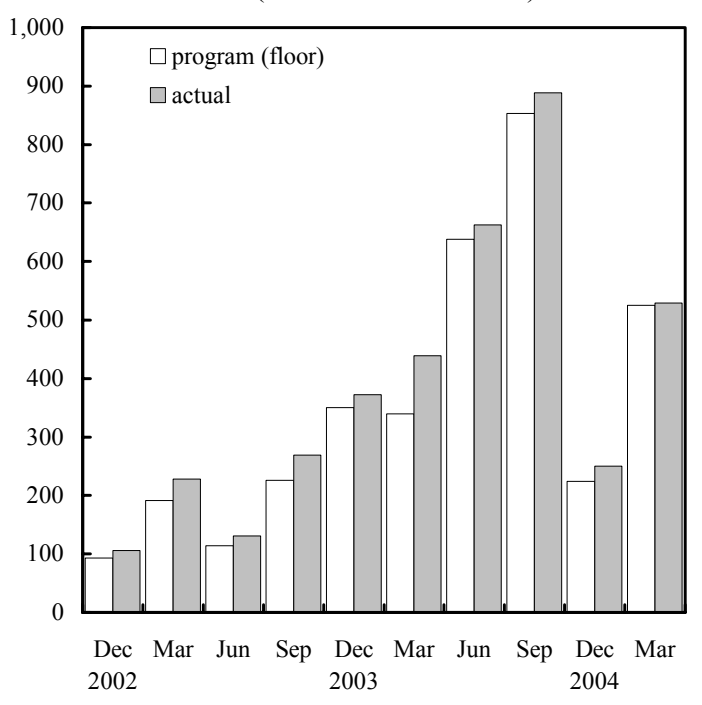

Sources: Tajik authorities; and Fund staff estimates.

$1 /$ Overall fiscal balance excludes the foreign-financed public investment program.

2/ Targets for overall fiscal balance and tax revenue in IMF Country Report No. 03/222 were cumulative from April 1, 2003. In IMF Country Report No. 04/17 and IMF Country Report No. 05/132 these targets were cumulative from October 1. 


\section{Consumer price inflation}

\section{rose recently owing to higher food}

prices. Inflation rose slightly to $6 \frac{1}{2}$ percent (12-month basis) in March 2005 but jumped to over 8 percent in April and May, partly because of a regional surge in potato and vegetable prices associated with weather-related supply shocks. Inflation for nonfood items and services remained low, at about $5 \frac{1}{2}$ percent. Although inflation has also picked up in other CIS countries, prudent macroeconomic

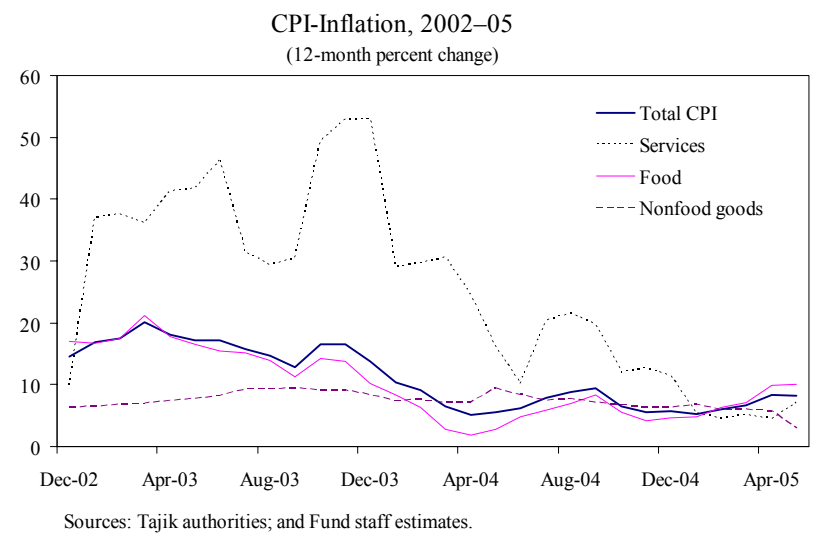
policies and shifting import patterns have so far dampened the impact of imported inflation in Tajikistan.

5. The authorities have been diligently implementing the financial program. The end-March 2005 quantitative performance criteria for net credit to the government, NDA of the NBT, and the overall budget deficit were observed with large margins. Net international reserves fell temporarily below the program floor due to the processing time for the disbursement of an EU program grant of $€ 7$ million, which took place in early May. ${ }^{1}$ Preliminary data as of May indicate that the authorities are on track for meeting the program's June targets.

Monetary Performance, March and May, 2005

(In millions of somoni; unless otherwise indicated)

\begin{tabular}{|c|c|c|c|c|c|c|}
\hline & \multicolumn{3}{|c|}{ End-March 2005} & \multicolumn{2}{|c|}{ End-June 2005} & \multirow{2}{*}{$\frac{\text { May }}{\text { Prel. }}$} \\
\hline & $\begin{array}{c}\text { Perf. Criteria } \\
\text { (IMF CR } \\
\text { No. 05/132) }\end{array}$ & $\begin{array}{l}\text { Adj. Perf. } \\
\text { Criteria 1/ }\end{array}$ & $\overline{\text { Actual }}$ & $\begin{array}{r}\text { Indicative } \\
\text { targets }\end{array}$ & $\begin{array}{c}\text { Indicative } \\
\text { targets (adj.) 1/ }\end{array}$ & \\
\hline Ceiling on net domestic assets of the NBT & 58 & 40 & 34 & 82 & 64 & 25 \\
\hline $\begin{array}{l}\text { Ceiling on net credit of the banking system } \\
\text { to government }\end{array}$ & -231 & -249 & -271 & -196 & -214 & -275 \\
\hline $\begin{array}{l}\text { Floor on net international reserves } \\
\text { (millions of U.S. dollars) } \\
\text { Reserve money (indicative target) }\end{array}$ & $\begin{array}{r}64 \\
252\end{array}$ & $\begin{array}{r}70 \\
252\end{array}$ & $\begin{array}{c}672 / \\
236\end{array}$ & $\begin{array}{r}58 \\
257\end{array}$ & $\begin{array}{r}64 \\
257\end{array}$ & $\begin{array}{r}77 \\
259\end{array}$ \\
\hline
\end{tabular}

Sources: National Bank of Tajikistan; and Fund staff estimates.

1/ Adjusted for disbursement of Asian Development Bank loan (\$5.8 million).

2/ Includes debt payment to EU of $€ 8$ million but excludes corresponding EU program grant of $€ 7$ million received only in early May 2005 .

\footnotetext{
${ }^{1}$ The program adjuster only covered disbursements of program loans. The adjuster will be changed to include disbursements of both program grants and loans from September 2005.
} 
6. Expenditure delays and strong nontax revenue resulted in a higher than planned fiscal surplus in the first quarter of 2005. The delays in expenditure execution were related to the introduction of the new budget classification system, and the recalculation of wages and pensions following the 2005 increase. $^{2}$ Tax revenue through May 2005 was in line with the program, as depressed tax receipts from cotton sales (owing to low cotton prices and delays in export shipments) were offset by higher-thanenvisaged VAT collections associated with strong consumer demand. New passport fees contributed to the higher nontax revenue. The end-March indicative target on new arrears to utility companies was missed because TadAZ accumulated some arrears $(0.1$ percent of GDP) to the electricity company. To address this problem, a bank payment mechanism was introduced in April (structural benchmark for March 2005).

7. Monetary policy has remained prudent. The larger than anticipated fiscal surplus contributed to a decline in reserve money to a level substantially below the end-March indicative program target. Following a subsequent pickup in government spending in May, reserve money returned to the targeted level (6 $1 / 2$ percent annual increase). Broad money continued to grow moderately through March (12 percent), while credit to the private sector increased by about 50 percent year-on-year, reflecting delays in the repayment, in late 2004-early 2005, of the foreignfinanced cotton credit granted in 2004 (Box 2). As envisaged in the program for 2005, the NBT reduced the required reserve ratio from 18 percent to 15 percent in May 2005 to improve the efficiency of commercial banks.

\footnotetext{
${ }^{2}$ In order to reverse their recent erosion in real terms, public service wages are being raised in two tranches by 50-100 percent in 2005. The nominal wage bill is budgeted to rise by 65 percent, with large increases in the education and health sectors.
} (12-month growth; in percent of reserve money)

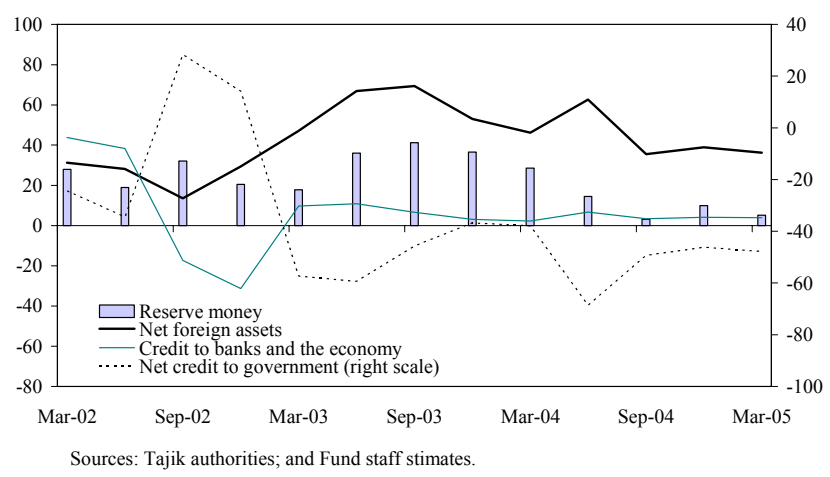

iscal Developments, 2003-05 (In percent of annual GDP)

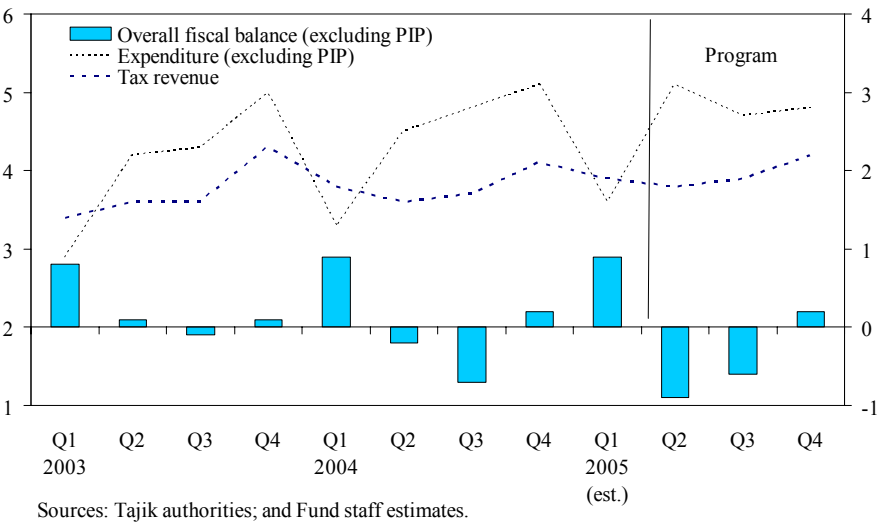

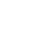




\section{Box 2. Tajikistan: Developments in Financial System Credit}

Financial system credit to the private sector rose rapidly (66 percent) in the year to March 2005. This expansion reflected a sharp increase in lending to the cotton sector in response to high cotton prices in early 2004. After financing for cotton planting was completed in April 2004, financial system credit remained relatively flat for most of the remainder of 2004. Most of the credit expansion is attributable to Kredit Invest, a nonbank financial intermediary and traditional source of cotton financing, with funding mainly from foreign sources but also increasingly from domestic bills.

More recently, Kredit Invest's ability to grant new loans has been severely restricted by the fall in cotton prices in late 2004 and early 2005. This fall led to repayment problems, and new lending is now conditional on clients' repayment of their 2004 loans. As a result, Kredit Invest's outstanding credit has not increased so far in 2005. To facilitate the resolution of cotton sector debts, the government has adopted a strategy based on negotiated agreements between creditors and debtor farms, assisted by a donor-funded independent commission.

Starting in 2005, commercial banks are playing an increasing, albeit still small, role in financing agricultural activities, with commercial bank credit growing by 33 percent in the year through March 2005. However, even after this increase, overall bank credit amounts to only $4 \frac{1}{2}$ percent of GDP.

The financing of the credit expansion by commercial banks came primarily from strong growth in the deposit base and the increase in banks' capital. Deposits at the commercial banks rose by 26 percent in the 12-months ending March 2005, with time and savings deposits surging by 57 percent. Commercial banks' capital rose by 19 percent owing to improved bank profitability and capital injections from shareholders of the four largest banks to meet the increased minimum capital requirements by January 1, 2005.

Developments in Financial Sector Credit and Deposits

\begin{tabular}{|c|c|c|c|c|c|c|}
\hline & \multicolumn{2}{|c|}{2004} & \multicolumn{2}{|c|}{2005} & \multicolumn{2}{|c|}{ Percentage change } \\
\hline & Q1 & Q4 & $\overline{\mathrm{Q} 1}$ & April & Q105/Q104 & Apr.05/Apr.04 \\
\hline Total financial sector credit & 588 & 941 & 974 & 996 & 65.5 & 19.4 \\
\hline $\begin{array}{l}\text { Commercial bank loans (in millions of somoni) } \\
\mathrm{o} / \mathrm{w} \text { share of credit to agriculture farms in total credit (in percent) }\end{array}$ & $\begin{array}{r}239 \\
12\end{array}$ & $\begin{array}{r}287 \\
12\end{array}$ & $\begin{array}{r}318 \\
17\end{array}$ & $\begin{array}{r}337 \\
16\end{array}$ & $\begin{array}{r}33.0 \\
\ldots\end{array}$ & $\begin{array}{r}37.3 \\
\ldots\end{array}$ \\
\hline Deposits and capital (in millions of somoni) & 377 & 433 & 463 & 509 & 22.8 & 35.8 \\
\hline Deposits (in millions of somoni) & 204 & 239 & 258 & 299 & 26.4 & 38.4 \\
\hline Share of deposits in financing (in percent) & 54 & 55 & 56 & 59 & $\ldots$ & . \\
\hline Capital and specific loan loss provisions (in millions of somoni) & 173 & 195 & 205 & 210 & 18.6 & 32.3 \\
\hline Share of capital in financing (in percent) & 46 & 45 & 44 & 41 & $\ldots$ & $\ldots$ \\
\hline Kredit Invest loans to cotton sector (in millions of somoni) & 349 & 654 & 656 & 659 & 87.7 & 12.0 \\
\hline Sources of financing (millions of somoni) & 351 & 661 & 659 & 659 & 87.4 & 11.6 \\
\hline Share of foreign financing (in percent) & 84 & 70 & 69 & 68 & $\ldots$ & $\ldots$ \\
\hline Share of domestic financing (in percent) & 16 & 30 & 31 & 32 & $\ldots$ & $\ldots$ \\
\hline
\end{tabular}

Source: National Bank of Tajikistan; and Fund staff estimates. 
8. The somoni remained relatively stable against the U.S. dollar within the framework of the managed float exchange rate regime. This relative stability was broken briefly in mid-May, following political unrest in Uzbekistan and the temporary closure of the borders, with the somoni/dollar rate settling at slightly below its March level. In the year to end-May 2005, the somoni depreciated by $3 \frac{1}{2}$ percent against the U.S. dollar, and by 10 percent in real effective terms, reflecting the weakening of the U.S. dollar against the currencies of Tajikistan's main trading partners. As of end-May 2005, the import cover of the NBT's gross international reserves remained at just under 2 months of prospective imports.
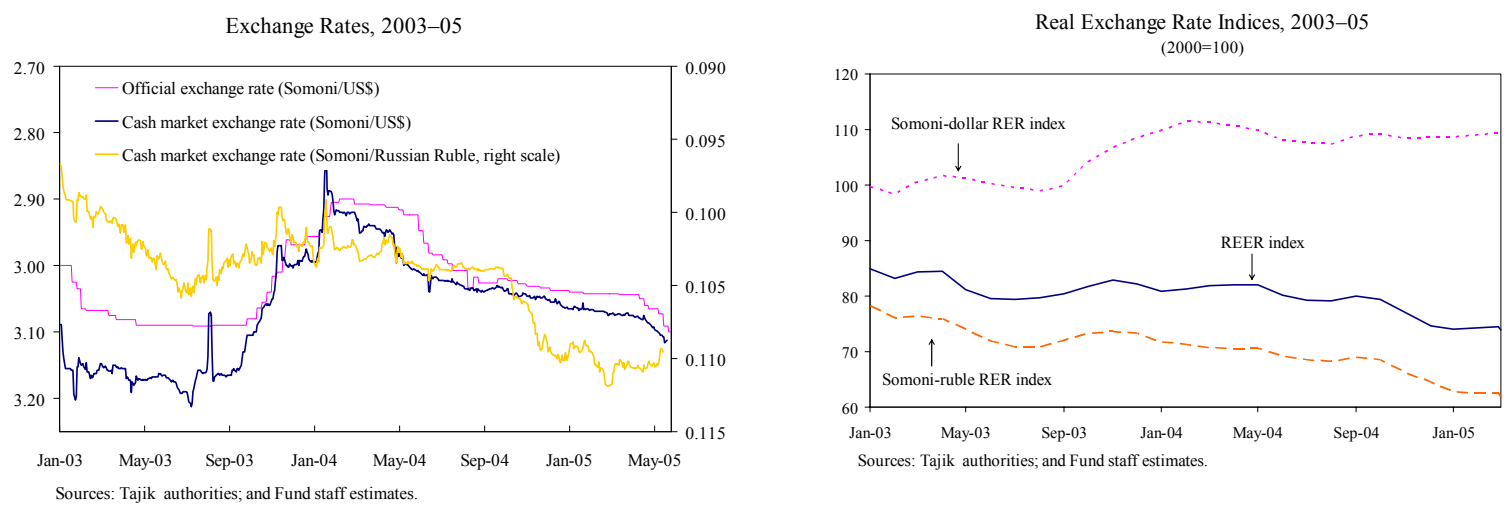

9. After increasing to 4 percent of GDP in 2004, the external current account deficit widened further in the first quarter of 2005. This deterioration was driven by a large increase in the trade deficit, reflecting weaker commodity prices, a lower export volume for cotton, and strong import growth, especially for consumer goods (Box 3). The impact of these developments on the current account was muted, however, by a significant increase in private transfers from abroad (up by 20 percent relative to the previous year).

10. Implementation of the structural agenda for March 2005 has been mixed. Of the two structural benchmarks for March 2005, one (on TadAZ) was fully completed with a minor delay. The new management of TadAZ set up a transit bank account for electricity payments in late April (rather than in March) to avoid future arrears, which is now fully operational. TadAZ's tax and electricity payments have been current since then. The other March benchmark (on rationalizing key economic planning functions) has been implemented only partially with the cessation of publication of detailed production targets. However, a detailed framework for unifying and rationalizing strategic planning functions has been agreed between government agencies and donors. This framework is expected to be formally adopted by early July 2005, with implementation by September.

\section{Substantial progress has been made on the structural benchmarks for}

June 2005. Amendments to the Banking Law to remove impediments to the entry of foreign banks have been approved by the government and will be submitted to parliament by early July. In addition, the external debt statistics have been expanded to include a large part of the external debt of the cotton sector. Recoveries of the NBT's claims on the private sector were only SM 4 million through early June, compared to the program target of SM 10 million by 


\section{Box 3. Is Tajikistan's Trade Deficit "Too High"?}

The Tajik authorities have recently raised concerns about the size and rate of increase of the trade deficit, which, based on customs data, was reported at 16 percent of GDP in 2004 (IMF Country Report No. 05/132). In particular, the authorities are concerned that the large trade deficit makes the economy vulnerable to external shocks and may reflect lack of competitiveness of domestic production. The staff has argued that it is important to assess the trade deficit in the context of the following broader factors:

- The actual size of the trade deficit is now estimated by staff at around 7 percent of GDP, about half the level indicated in the customs statistics. A survey on the purpose of remittances shows that about 40 percent of

Table 1. Trade Balance and Current Account Balance, 2001-05

\begin{tabular}{lrrrrr}
\hline & (In percent of GDP) \\
& 2001 & 2002 & 2003 & 2004 & 2005(pr) \\
\hline Exports (after reclassification) & 63.6 & 61.2 & 57.9 & 52.5 & 47.9 \\
Exports (before reclassification) & 63.1 & 58.6 & 51.3 & 44.1 & 42.0 \\
Imports & 73.5 & 69.1 & 64.5 & 59.8 & 57.7 \\
Openness (Ex+Im) & 140.3 & 130.3 & 122.3 & 112.2 & 109.2 \\
Trade balance (after reclassification) & -9.9 & -7.9 & -6.6 & -7.3 & -9.9 \\
Trade balance (before reclassification) & -10.4 & -10.5 & -13.2 & -15.7 & -16.7 \\
\hline
\end{tabular}
inward remittances were payments for small (mainly agricultural) exports (Table 1). If these remittances are reclassified starting in 2001 (the first year with major recorded remittances), the trade deficit would be significantly lower because of the stronger growth of exports.

- The increase in the trade deficit in 2005 is mainly due to a deterioration in the terms of trade (Figure 1a). The impact on the current account deficit is expected to be offset by higher net remittances and services.

- Vulnerability has been partly reduced by the decline in imports in relation to GDP. Imports were high in the late 1990s because of unstable conditions related to the civil war, but the domestic economy has recovered substantially since then, outpacing import growth despite the sharp increase in oil prices.

- Although imports have grown faster Table 2. Direction of Trade, in percent of total than exports, a large part of the increase in imports has been selffinanced, especially through remittances and project loans (Figure 1b). The high import content of this financing reduces the pressure for exchange rate appreciation.

\begin{tabular}{lccccc}
\hline & 2000 & 2001 & 2002 & 2003 & 2004 \\
\hline & & & & & \\
\hline Exports, CIS & 45.0 & 32.0 & 21.1 & 17.5 & 17.5 \\
Imports, CIS & 83.0 & 79.2 & 74.8 & 68.0 & 69.6 \\
\hline
\end{tabular}

- Vulnerability has also been reduced by the increase in the product and geographic diversification of trade. Figures $1 \mathrm{c}$ and $1 \mathrm{~d}$ show that the relative size of commodity exports, especially aluminum and cotton, has declined. In addition, Table 2 shows that the relative contribution of the CIS countries as an export destination has declined sharply; this applies to both commodity and noncommodity exports. 


\section{Box 3. Is Tajikistan's Trade Deficit “Too High”? (concluded)}

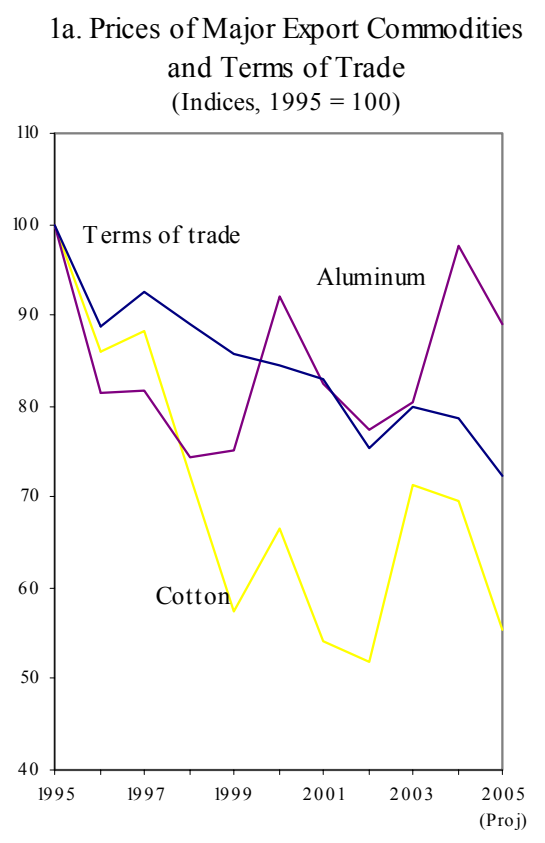

1c. Composition of Exports (In percent of GDP)

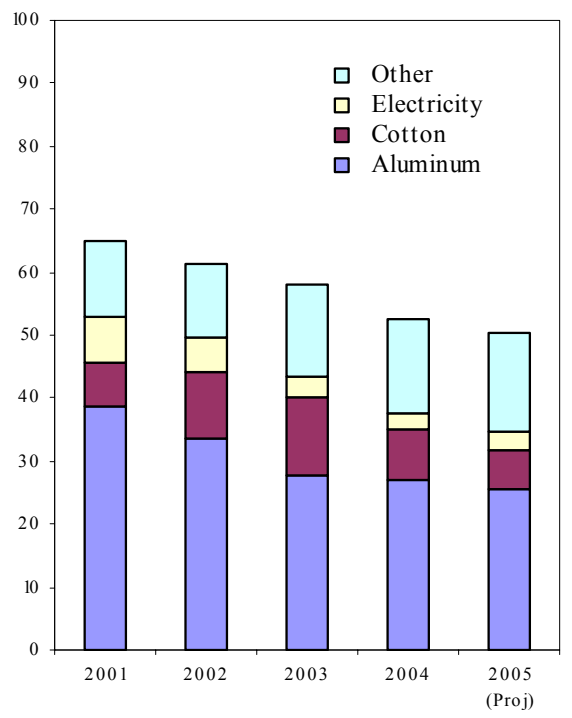

1b. Other Imports

(In millions of U.S. dollars)

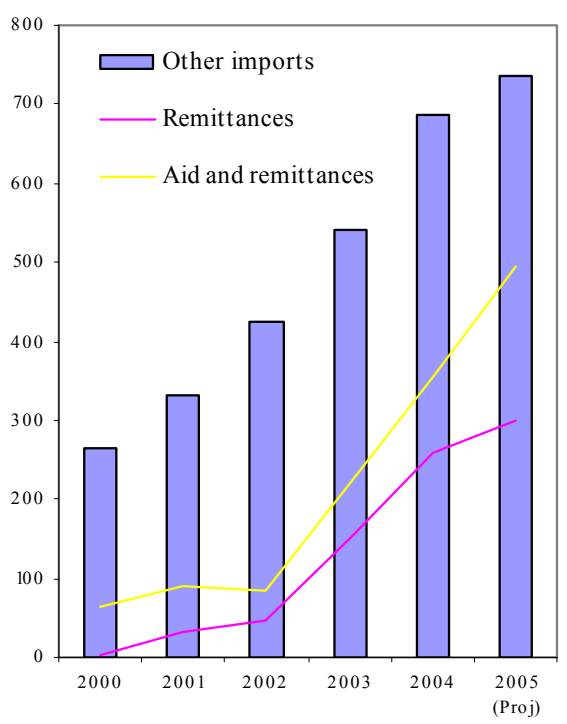

1d. Composition of Imports (In percent of GDP)

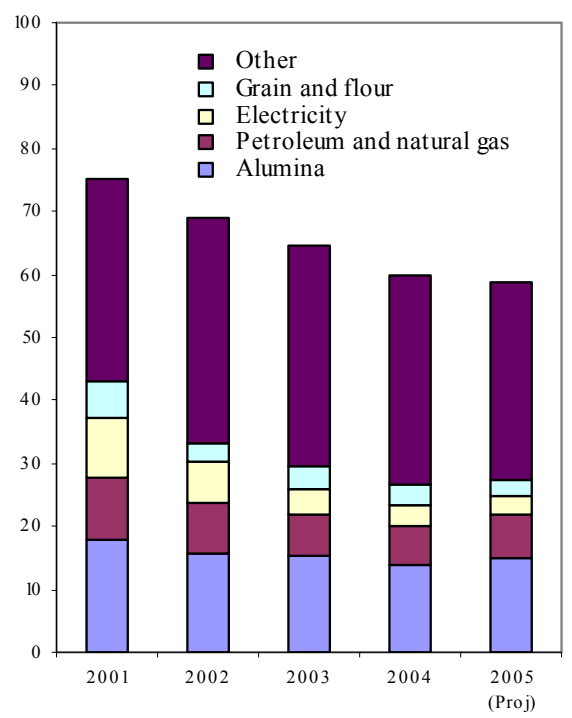

Sources: Tajik authorities; and Fund staff calculations. 
end-June, but additional amounts are expected to be received by early July. Also, on account of the impact of lower cotton prices on tax payments by cotton producers, ${ }^{3}$ the expansion in the coverage of the large taxpayer inspectorate (LTI) fell short of the target envisaged under the June benchmark (60 percent of total tax collections). Nevertheless, the authorities have maintained efforts to add taxpayers to the LTI's coverage, and are expected to raise the LTI's contribution to tax collection by 5 percentage points by end-June-consistent with the implied increase under the original benchmark.

\section{Policy Discussions ANd the Program for 2005}

\section{Discussions with the authorities focused on strengthening macroeconomic} performance and the implementation of structural measures within a weaker economic environment. On the macroeconomic front, the diversification of the economy due to higher remittances and agricultural reforms (including land privatization) has helped reduce the impact of weaker commodity prices on output, but further efforts are needed to sustain high growth rates over the medium term. From the structural perspective, the authorities recognize that, notwithstanding prospective large-scale energy sector investments, further improvements in the business environment and economic governance are needed to support broad-based growth. Moreover, the authorities are intent on strengthening the delivery of education and health services. However, despite close cooperation with development partners, many obstacles continue to limit the pace of reform, including budgetary constraints, low technical capacity, and hesitancy at adopting new approaches. In this regard, the authorities stressed their commitment to market reforms, but indicated that they needed more time to be able to implement effectively their structural reform agenda.

\section{The authorities expressed interest in a successor PRGF arrangement to help} them move forward with their pending reform agenda. To evaluate the progress made under the Fund-supported programs, the staff will prepare an Ex Post Assessment of Longer-Term Program Engagement ahead of the sixth review under the arrangement.

\section{A. Macroeconomic Outlook}

14. Overall, the macroeconomic outlook has weakened somewhat since the fourth review under the PRGF. Although the program's projection of 8 percent growth in 2005 is still achievable, the 2005 inflation target has been raised slightly to 7 percent, owing to some depreciation of the currency in recent months. This small revision assumes that the spike in food prices is of a temporary nature.

\footnotetext{
${ }^{3}$ This factor reduced LTI coverage from 55 percent in 2004 to 52 percent in early 2005.
} 

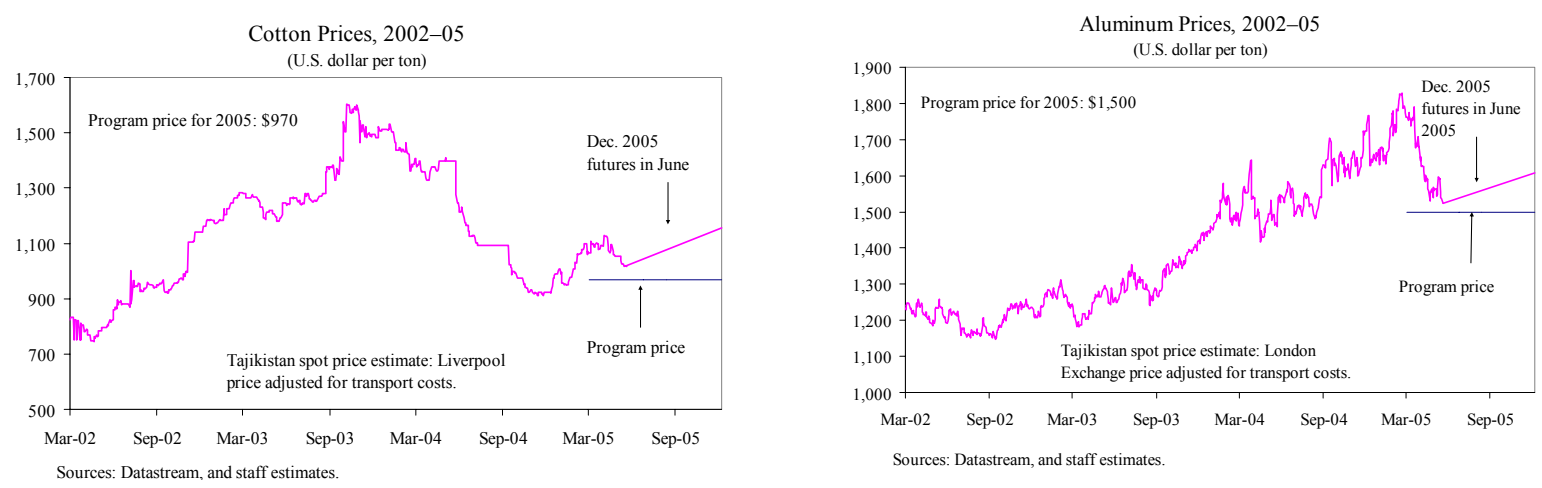

15. Based on recent trends, the external current account deficit would widen to about 5 percent of GDP in 2005. The program price for aluminum has been reduced because of recent trends and, although the program price for cotton has been kept unchanged, the outlook for cotton exports remains weak. The deterioration of the terms of trade and higher aid and remittance-funded imports are expected to lead to a trade deficit of 10 percent of GDP in 2005. However, much of this will be offset by higher net remittances from abroad and an improved balance on services. The larger current account deficit will be financed mainly by higher disbursements of concessional loans and grants, which are now projected at $\$ 140$ million (6 percent of GDP) in 2005 . The gross reserves coverage will remain at just under 2 months of imports through year's end.
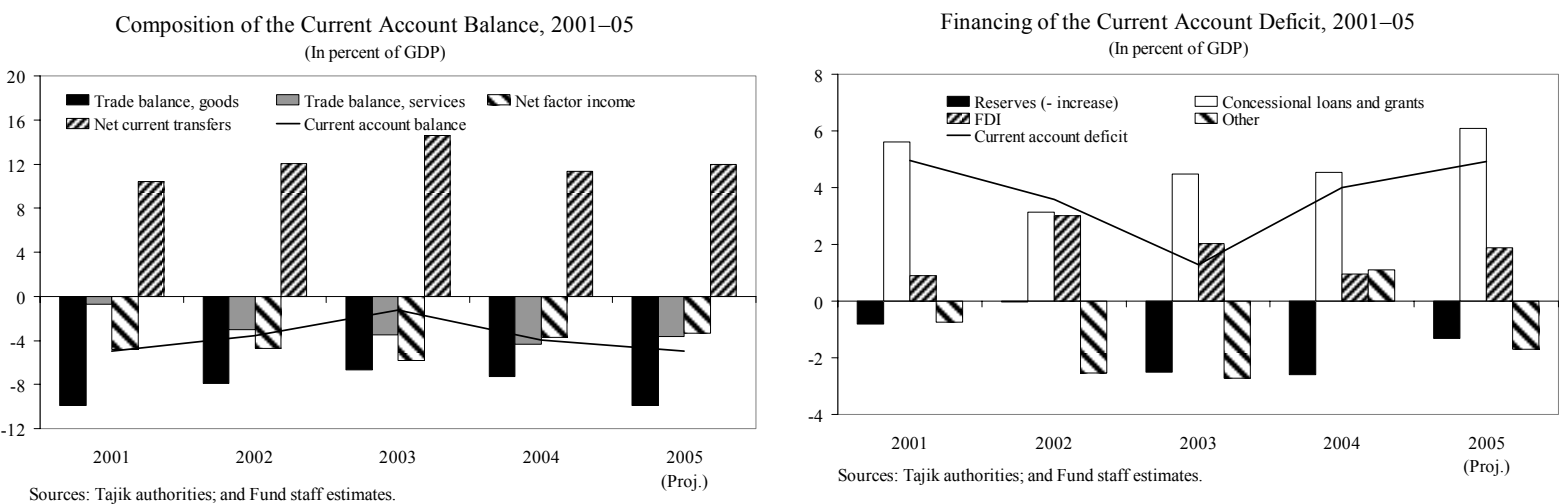

\section{B. Fiscal Policy}

16. The authorities reiterated their commitment to maintaining a prudent fiscal policy. Revenue and expenditure are expected to be in line with the 2005 budget. At the same time, a reclassification of foreign financing from the EU as grants will reduce the overall budget deficit after grants (excluding the foreign financed PIP) to close to balance. Domestic bank financing of the deficit will increase slightly relative to the original program, to 0.6 percent of GDP, in order to compensate for delays in the disbursement of a World Bank program loan. 
17. Despite the weaker commodity prices, the strong VAT performance experienced in recent months should enable the authorities to achieve the program's tax revenue target of 15.7 percent of GDP. To provide an added cushion, the authorities are strengthening tax administration, with special emphasis on increasing revenue from the domestic VAT and excise duties. While the new tax and customs codes have improved the tax structure and taxpayer rights, tax officials are still in the process of adjusting to the new framework. ${ }^{4}$ In particular, revised procedures and interpretations are being developed to address VAT credit fraud and tax loopholes. The annual projection for nontax revenue has been increased slightly in light of the higher collections from passport fees.

\section{The authorities are aware of the need to avoid an erosion of the tax revenue} collected from TadAZ. Discussions with RUSAL (TadAZ's new Russian partner) on possible modifications to TadAZ's medium-term tax regime in exchange for RUSAL's investment in Tajikistan's aluminum and energy sectors are ongoing. The authorities confirmed, however, that the current tax arrangements will remain in place during the remainder of 2005, and that any future changes in tax arrangements will be transparent and will be carefully analyzed for their revenue implications to avoid an erosion of the tax base. This issue will be discussed in detail in the context of the sixth review under the PRGF.

19. Discussions on expenditure focused on the distribution of the second tranche of the wage increase for 2005 (equivalent to SM 16 million or 0.2 percent of GDP). Overall, the government is confident that spending will be kept in line with the budget and that a cautious execution should provide sufficient flexibility to restrain expenditures in case of a revenue shortfall. The second tranche of the wage bill will be distributed to sectors implementing the planned reforms foreshadowed in the third annual program. Since education reforms have started in five pilot rayons, this sector has already been allocated SM 4 million. The remaining SM 12 million (including about SM 6 million for the civil service) will be made available after September 2005, conditional on the completion of the civil service registries, adoption of a rationalized wage structure, and implementation of administrative and health reforms.

20. The authorities are making further progress in improving budget management and transparency. After the successful implementation of the new budget information and classification systems at the start of 2005, the MOF is in the process of extending automation to the treasury system, especially to the cash management unit (part of the structural benchmark for September 2005). In addition, the public availability of the detailed budget and its outcome will be broadened, including through the internet. Preparations are also underway to incorporate in the 2006 budget the recent financing reforms in education and health care (see below). An FAD technical assistance mission will conduct a comprehensive review of the expenditure management system in early-July 2005.

\footnotetext{
${ }^{4}$ The new tax and customs codes were introduced at the start of 2005; technical support for the former was provided by LEG, and for the latter by USAID. Further technical assistance from FAD is envisaged in Q3 2005 to support continued revenue administration reforms.
} 


\section{Monetary and External Policies}

21. The authorities considered that the use of reserve money targets has served them well, as demonstrated by the significant reduction in inflation over the past two years. Since developments so far in 2005 have been broadly in line with the program, the authorities are retaining the monetary targets for 2005, including reserve money growth of 10 percent for the year. Given the increase in the money multiplier associated with the recent reduction in the required reserve ratio, which had already been taken into account when the program was designed, this expansion in reserve money is expected to support broad money growth of 18 percent in 2005. As the rapid increase in financial system credit in early 2005 was due to new seasonal credit on top of late repayments of the old stock, further large increases are not expected during the remainder of the year. Also, the NBT will intensify its efforts to recover credit and will refrain from providing new loans. In order to broaden the spectrum of available monetary instruments, the MOF is introducing SM 3 million in shortterm tradable securities that could be used for open market operations and as collateral for interbank loans.

22. The operation of the managed float exchange regime remains broadly appropriate, with intervention limited to reducing excess volatility. To strengthen the system further, the NBT will start to adjust the official exchange rate on a daily basis by endAugust 2005.

23. The authorities will continue to monitor closely the commitments on new external debt to avoid nonconcessional government and government-guaranteed debt and maintain debt sustainability. The debt tracking system is now operational and the MOF is starting to build up capacity for debt forecasting and debt sustainability analysis. The authorities are also seeking further bilateral debt relief, following recent progress with some of the largest bilateral creditors (Russia and Pakistan). The NBT will extend the coverage of the data on private external debt for the rest of the cotton sector and will systematize the reporting system.

\section{Structural Reforms and Poverty Reduction Strategy}

24. The authorities recognized that the implementation of structural reforms in some areas has been slow. The Annual Progress Report (APR) on PRSP implementation, which is currently under preparation, attributes the delays to policy trade-offs and capacity limitations, especially at the local level. ${ }^{6}$ In the discussions on the strategy for a new PRSP,

\footnotetext{
${ }^{5}$ The spread between the official and market rates has remained within 1 percent since mid-2004. Since the calculation of the daily official exchange rate will also include transactions between banks and their clients, this spread is expected to decline further.

${ }^{6}$ The first APR was issued in June 2004 (www.imf.org).
} 
the authorities indicated they are designing a new national development strategy that would have a strong focus on growth-oriented policies, such as the provision of economic infrastructure and improvements in the business and governance environment, especially for small- and medium-sized enterprises.

25. Reflecting the priority assigned to agriculture in the poverty reduction efforts, since March 2005 the government has been implementing and refining its cotton reform strategy. The strategy includes a process of negotiated debt resolution between creditors and debtor farms, facilitated by a donor-funded independent commission for which the terms of reference are being developed. The authorities are in close contact with donors to ensure that agricultural reforms effectively remove local interference in production decisions, equitably distribute land, and properly liberalize marketing arrangements to promote a more efficient and diversified agricultural sector.

26. A prudent expansion of the banking system constitutes a key element to support private sector development. The NBT, aided by USAID consultants, will continue to upgrade banking supervision, including by using the new reporting system to better monitor prudential norms, tightening key regulations, and helping commercial banks strengthen their internal controls. The NBT will also enhance the monitoring of the quality of loan portfolios, particularly for those banks that have expanded lending rapidly in recent months, and will continue recovering central bank credit to the economy to strengthen its capital position and improve credit discipline. The introduction of a higher minimum capital requirement starting in 2006 is expected to encourage a consolidation of the banking sector. The authorities indicated that there was growing interest among foreign banks to operate in Tajikistan, and that approval by parliament of the amendments to the Banking Law would facilitate entry by foreign institutions.

27. The authorities are moving ahead with further reforms in the energy sector to support prospective large investments. As part of a rehabilitation program supported by the World Bank, they have undertaken to raise electricity prices progressively over the next five years in order to virtually eliminate the quasi-fiscal deficit by 2010 . This will be accompanied by steps to ameliorate the impact on vulnerable groups. In addition, international standard audits will be conducted for the electricity and gas companies, as well as for TadAZ.

28. The authorities pointed to the progress made on education and health reforms that are being implemented in close consultation with a range of development partners. In the education sector, rationalization measures proposed in the June 2004 education strategy are continuing, and financial management reforms were introduced in 5 large pilot rayons. In the health sector, a financing reform strategy was approved in May 2005 that provides for a guaranteed benefits package, including primary health care and funding for other services based on co-payments. This reform is being piloted in two large rayons ahead of a wider rollout in 2006 . 
29. Civil service reforms, which are supported in part by the World Bank's Policy Based Credit, are now advancing following some initial delays. Work is proceeding on the civil service registers of positions and staff (already completed for the central government), revisions to the civil service code, and the rationalization of the employee compensation system. The authorities explained that the slow progress in restructuring the economic bloc was due to an ongoing debate on the final structure of the government. Recognizing the importance of moving ahead in this area, an agreement was reached recently on the rationalization of the planning functions, and other reforms in the pilot ministries, which would be implemented by September 2005 .

\section{E. Program Monitoring and Risks}

30. The program will continue to be monitored on the basis of the same performance criteria, benchmarks, and indicative targets included at the time of the fourth review under the PRGF. The pending elements of the benchmarks for 2005 will be implemented, subject to the understandings in the supplementary MEFP, ahead of the completion of the sixth review. To allow sufficient time for this purpose, it is proposed that the arrangement be extended by two months to February 10, 2006.

31. The main near-term risks to the program come from a possible further deterioration of the external environment. Specifically, the fall in cotton and aluminum prices could be more pronounced than projected if global growth were to weaken, and higher oil prices would increase the import bill and impose additional costs on agriculture. Moreover, if political unrest in the region disrupts transit arrangements, there could be a major impact on trade, growth, and inflation. On the upside, further domestic reforms could enable Tajikistan to take advantage of higher growth in Russia and Kazakhstan, and an early start of the construction of large hydro-electric projects could add to near-term growth.

\section{Staff Appraisal}

32. The Tajik authorities have continued to make good progress at strengthening macroeconomic management. Fiscal policy has been cautious and monetary management continues to improve. As a result, the exchange rate has been relatively stable and underlying inflation remains in check. Despite weaker commodity export prices, economic growth is likely to slow only modestly from 2004. Looking forward, the authorities need to continue working on building the political consensus required to accelerate the reform process in order to strengthen growth prospects and reduce vulnerabilities.

33. The fiscal surplus in early 2005 bodes well for achieving the annual budget targets. Revenue should be monitored closely during the remainder of the year, especially in view of the weakness of the main commodity prices and the ongoing implementation of the new tax and customs codes. Any revenue shortfall will need to be promptly compensated by restraining expenditure below the budget appropriations, while protecting the social sectors. In addition, the revenue arrangements for the energy/aluminum sectors should be designed in 
a transparent manner and should be consistent with preserving the revenue base. Envisaged reforms to improve treasury operations and fiscal transparency will enhance the formulation and conduct of fiscal policy and should be implemented expeditiously.

\section{Monetary policy has contributed to limiting inflationary pressures, assisted by} the prudent implementation of the budget. Achieving the program's monetary targets will be key to keeping inflation at a moderate level. In this regard, the envisaged steps to expand the range of monetary instruments will enhance monetary management. Regarding the financial system, the ongoing efforts at raising capital requirements and improving the reporting of prudential data are welcome, as is the strengthened monitoring of banks' loan portfolios. Prompt approval of the legislation aimed at eliminating the bias against foreign banks would be an important step toward further strengthening the banking system and improving the quality of financial services.

35. The managed floating exchange rate regime remains appropriate, and the planned move to daily market-based determination of the official exchange rate is a welcome step that should improve the functioning of the foreign exchange market.

36. Recent steps to improve the management of external debt are paying off. The policy of refraining from the use of nonconcessional government and government guaranteed debt should be continued. Efforts should also be intensified to complete promptly the database for private external debt owed by the cotton sector.

37. The staff supports the reform of the cotton and electricity sectors. Improving rural incomes in the face of low cotton prices will require skillful implementation of appropriate cotton sector reforms including debt resolution without granting government guarantees. Liberalization of production and marketing arrangements for cotton will also promote diversification and efficiency. In the electricity sector, policy discussions with the World Bank have resulted in the development of a consistent energy sector strategy that requires vigorous implementation, especially with respect to an early start of the phased increases in electricity prices and strengthened enforcement of payments and financial governance.

38. Public sector reform should be accelerated. Although significant progress has been made in the areas of education and health, there is a need to press ahead with the restructuring of the pilot ministries in order to adapt the institutional framework to the requirements of a market economy.

39. In view of the authorities' satisfactory implementation of the program during the first half of the year, the staff recommends completion of the fifth review under the PRGF. The staff also supports the authorities' request for a waiver for the nonobservance of the endMarch 2005 performance criterion on NIR, as well as the extension of the PRGF arrangement for two months to facilitate the completion of pending reforms. 
Table 1. Tajikistan: Selected Macroeconomic Indicators, 2001-05

(Quota: SDR 87 million)

(Population: 6.5 million)

(Per capita GDP: \$310; Per capita GNP: \$370, 2004)

\begin{tabular}{|c|c|c|c|c|c|c|}
\hline & \multirow[t]{2}{*}{2001} & \multirow[t]{2}{*}{2002} & \multirow[t]{2}{*}{2003} & \multirow[t]{2}{*}{2004} & \multicolumn{2}{|c|}{2005} \\
\hline & & & & & Q1 & Revised prog. \\
\hline & \multicolumn{6}{|c|}{ (Annual percent change, unless otherwise indicated) } \\
\hline \multicolumn{7}{|l|}{ National accounts } \\
\hline Nominal GDP (in millions of somoni) & 2,512 & 3,345 & 4,758 & 6,158 & 1,274 & 7,100 \\
\hline Nominal GDP (in millions of dollars) & 1,051 & 1,197 & 1,556 & 2,073 & 410 & 2,338 \\
\hline Real GDP & 10.2 & 9.1 & 10.2 & 10.6 & $7.51 /$ & 8.0 \\
\hline CPI inflation (end-of-period) & 12.5 & 14.5 & 13.7 & 5.6 & $8.21 /$ & 7.0 \\
\hline Poverty rate (in percent of population) & 65.4 & $\ldots$ & 64.0 & $\ldots$ & $\ldots$ & $\ldots$ \\
\hline & \multicolumn{6}{|c|}{ (In percent of GDP) } \\
\hline \multicolumn{7}{|l|}{ Investment and savings $2 /$} \\
\hline Investment & 16.7 & 13.9 & 13.1 & 14.9 & $\ldots$ & 15.5 \\
\hline Fixed capital investment & 9.3 & 10.9 & 12.0 & 13.5 & $\cdots$ & 14.0 \\
\hline Government & 5.1 & 5.4 & 6.5 & 8.1 & $\ldots$ & 8.0 \\
\hline Private & 4.2 & 5.4 & 5.5 & 5.4 & $\ldots$ & 5.9 \\
\hline Gross national savings & 11.6 & 10.3 & 11.9 & 10.9 & $\ldots$ & 10.6 \\
\hline Public & 1.9 & 3.0 & 4.8 & 5.8 & $\ldots$ & 3.9 \\
\hline Private & 9.8 & 7.3 & 7.1 & 5.4 & $\ldots$ & 6.6 \\
\hline Savings/investment balance & -5.1 & -3.6 & -1.3 & -4.0 & $\ldots$ & -4.9 \\
\hline & \multicolumn{6}{|c|}{ (In percent of annual GDP) } \\
\hline \multicolumn{7}{|l|}{ Budgetary operations } \\
\hline Revenue and grants & 15.2 & 16.7 & 17.3 & 17.9 & 4.4 & 18.1 \\
\hline Of which: tax revenue & 14.1 & 15.0 & 15.0 & 15.2 & 3.9 & 15.7 \\
\hline Expenditure and net lending & 18.4 & 19.2 & 19.1 & 20.3 & 4.3 & 22.2 \\
\hline Of which: current & 13.2 & 13.7 & 12.6 & 12.1 & 3.0 & 14.1 \\
\hline capital & 5.1 & 5.4 & 6.5 & 8.1 & 1.6 & 8.0 \\
\hline Balance (excluding debt-financed PIP) & -0.1 & -0.1 & 0.9 & 0.7 & 0.9 & -0.1 \\
\hline Balance (including debt-financed PIP) & -3.2 & -2.4 & -1.8 & -2.4 & 0.1 & -4.1 \\
\hline Domestic financing & -0.8 & -0.1 & -1.1 & -1.7 & -0.6 & 0.9 \\
\hline \multirow[t]{2}{*}{ External financing } & 3.0 & 2.6 & 2.8 & 4.0 & 0.5 & 3.2 \\
\hline & \multicolumn{6}{|c|}{ (12-month growth in percent of broad money, unless otherwise indicated) } \\
\hline \multicolumn{7}{|l|}{ Monetary sector 3/ } \\
\hline Net foreign assets & -38.2 & -7.5 & 48.8 & -22.3 & $20.94 /$ & 2.1 \\
\hline Net domestic assets & 86.0 & 45.9 & -21.4 & 78.8 & $19.44 /$ & 15.0 \\
\hline Broad money & 40.0 & 39.7 & 29.2 & 14.3 & $25.64 /$ & 18.4 \\
\hline Bills payable & 7.9 & -1.3 & -1.8 & 42.2 & $14.74 /$ & -1.4 \\
\hline Velocity of broad money (four-quarter average) & 3.1 & 3.4 & 3.0 & 3.8 & $3.84 /$ & 3.7 \\
\hline Interest rate (28-day NBT bill rate, in percent) & 18.1 & 23.1 & 4.9 & 6.2 & $6.05 /$ & $\ldots$ \\
\hline & \multicolumn{6}{|c|}{ (In millions of U.S. dollars, unless otherwise indicated) } \\
\hline \multicolumn{7}{|l|}{ External sector } \\
\hline Exports of goods and services & 735 & 799 & 985 & 1,211 & 271 & 1,253 \\
\hline Annual percent change & -13.5 & 8.8 & 23.2 & 22.9 & -3.0 & 3.5 \\
\hline Imports of goods and services & 847 & 929 & 1,142 & 1,451 & 334 & 1,568 \\
\hline Annual percent change & -2.5 & 9.7 & 22.9 & 27.1 & 9.8 & 8.1 \\
\hline Current account balance & -52 & -43 & -20 & -83 & -25 & -115 \\
\hline In percent of annual GDP & -5.1 & -3.6 & -1.3 & -4.0 & -1.1 & -4.9 \\
\hline Total public sector external debt & 1,017 & 1,009 & 1,031 & 853 & $\ldots$ & 897 \\
\hline In percent of GDP & 96.7 & 84.3 & 66.2 & 41.1 & $\ldots$ & 38.4 \\
\hline Gross official reserves & 96 & 96 & 135 & 189 & $2131 /$ & 205 \\
\hline In months of imports & 1.9 & 1.8 & 1.9 & 1.8 & 1.8 & 1.9 \\
\hline \multicolumn{7}{|l|}{ Memorandum items: } \\
\hline Nominal effective exchange rate (Index 1999=100) & 66.8 & 58.9 & 49.4 & 46.9 & 46.8 & $\ldots$ \\
\hline Real effective exchange rate (Index 1999=100) & 96.1 & 87.3 & 79.1 & 75.5 & 74.7 & $\ldots$ \\
\hline Average exchange rate (somoni per dollar) & 2.4 & 2.8 & 3.1 & 2.97 & $3.115 /$ & $\ldots$ \\
\hline
\end{tabular}

Sources: Data provided by the Tajikistan authorities; and Fund staff estimates.

1/ As of May 2005.

2/ Private investment and savings are estimates.

3/ The definition of broad money was revised in 2004 .

4/ As of April 2005.

5/ As of June 9, 2005. 
Table 2. Tajikistan: Basic Social Indicators, 1970-2003

\begin{tabular}{|c|c|c|c|c|c|c|}
\hline & \multicolumn{4}{|c|}{ Tajikistan } & \multirow{2}{*}{$\begin{array}{c}\text { Europe and } \\
\text { Central } \\
\text { Asia 1/ }\end{array}$} & \multirow{2}{*}{$\begin{array}{c}\text { Low- } \\
\text { income } \\
\text { countries 1/ }\end{array}$} \\
\hline & $1970-75$ & $1980-85$ & $1990-99$ & $2000-031 /$ & & \\
\hline \multicolumn{7}{|l|}{ Population 2/ } \\
\hline Life expectancy at birth (in years) & 64 & 66 & 69 & 66 & 69 & 59 \\
\hline Infant mortality (per thousand live births) & $\ldots$ & 58 & 19.9 & $\ldots$ & 30.7 & 76.0 \\
\hline Birth rate, crude (per thousand people) & $\ldots$ & $\ldots$ & 22.0 & 22.6 & 12.7 & 28.6 \\
\hline Death rate, crude (per thousand people) & $\ldots$ & $\ldots$ & 5.2 & 6.7 & 11.8 & 10.8 \\
\hline Fertility rate (in births per woman) & 6.3 & 5.6 & 3.3 & 2.9 & 1.6 & 3.5 \\
\hline Age dependency ratio (in percent) & $\ldots$ & 0.90 & 0.80 & 0.73 & 0.48 & 0.69 \\
\hline Rural population (in percent of population) & 64.5 & 66.0 & 72.5 & 72.4 & 36.4 & 69.4 \\
\hline Urban population (in percent of population) & 35.5 & 34.0 & 27.5 & 27.6 & 63.7 & 30.6 \\
\hline \multicolumn{7}{|l|}{ Health indicators } \\
\hline $\begin{array}{l}\text { Child immunization: Measles (in percent of children } \\
\text { under } 12 \text { months) } 3 \text { / }\end{array}$ & $\cdots$ & $\cdots$ & 79 & 87 & 93 & 65 \\
\hline $\begin{array}{l}\text { Child immunization: DPT (in percent of children } \\
\text { under } 12 \text { months) 3/ }\end{array}$ & $\cdots$ & $\cdots$ & 81 & 84 & 92 & 65 \\
\hline Physicians (per thousand people) & $\ldots$ & 2.4 & 2.0 & 2.1 & 3.1 & $\ldots$ \\
\hline Hospital beds (per thousand people) & $\ldots$ & 10.0 & 8.8 & 6.4 & 8.9 & $\ldots$ \\
\hline \multicolumn{7}{|l|}{ Education 2/ } \\
\hline Gross primary school enrollment rate (in percent of age group) & $\ldots$ & $\ldots$ & 95 & 107 & 99 & 94 \\
\hline Gross secondary school enrollment rate (in percent of age group) & $\ldots$ & $\ldots$ & 78 & 82 & 86 & 46 \\
\hline
\end{tabular}

Sources: World Development Indicators; the World Bank Group.

1/ Latest data available.

2/ Data in the column labelled 1990-99 is the period average for 1993-99.

3/ Data in the column labelled 1990-99 is the period average for 1995-99. 
Table 3. Tajikistan: General Government Operations, 2003-05

(In millions of somoni; unless otherwise indicated)

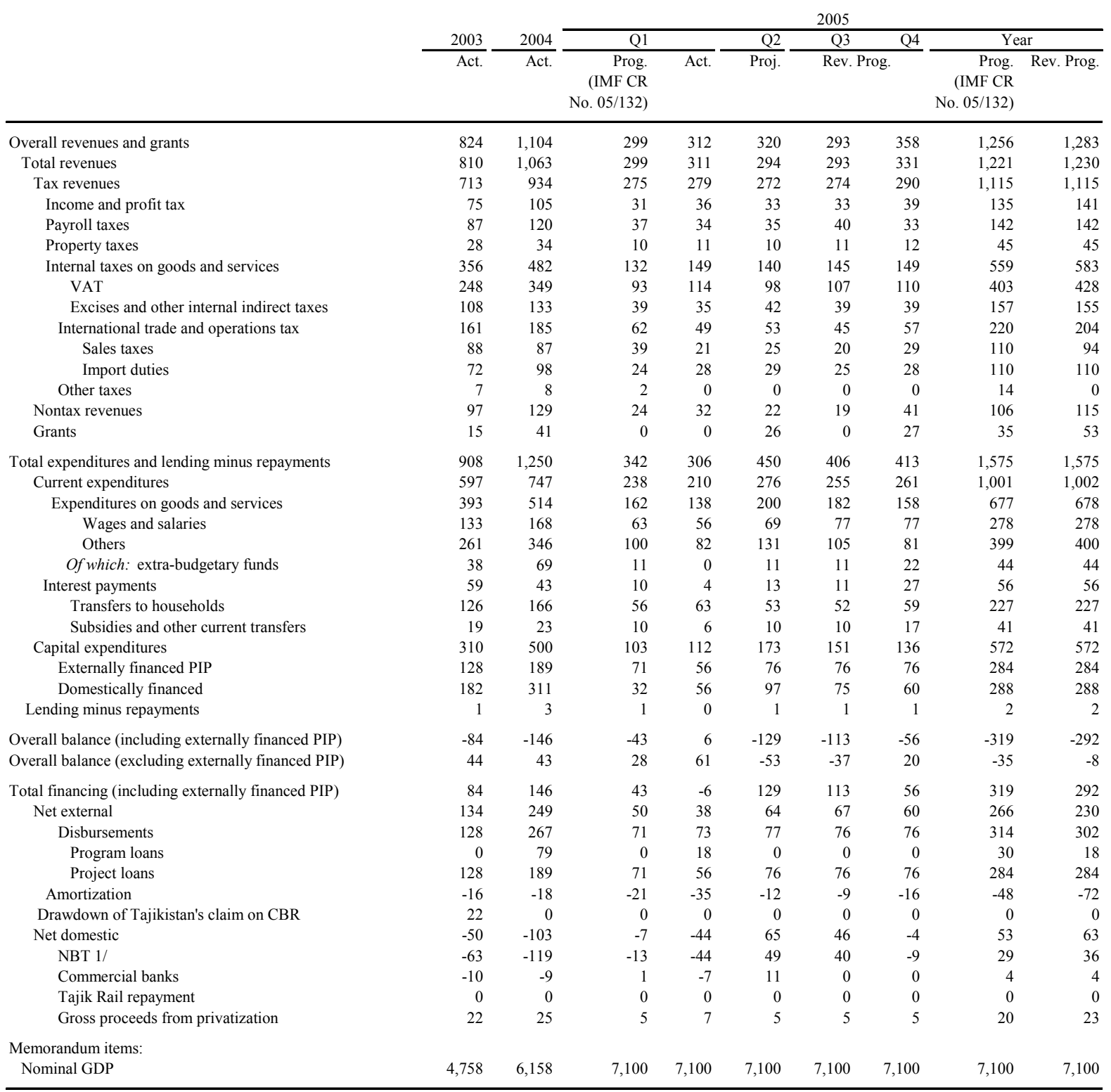

Sources: Tajik authorities; and Fund staff estimates.

1/ Differences between the historical financing figures and those in the NBT accounts are due to the inclusion of undisbursed project financing in the

NBT's accounts with government. Also, the historical financing figures in this table are based on estimated flows, not differences between end-period stocks. 
Table 4. Tajikistan: General Government Operations, 2003-05

(In percent of GDP; unless otherwise indicated)

\begin{tabular}{|c|c|c|c|c|c|c|c|c|c|}
\hline & \multirow{3}{*}{$\frac{2003}{\text { Actual }}$} & \multirow{3}{*}{$\frac{2004}{\text { Actual }}$} & \multicolumn{7}{|c|}{2005} \\
\hline & & & \multicolumn{2}{|l|}{ Q1 } & \multirow{2}{*}{$\frac{\mathrm{Q} 2}{\text { Proj. }}$} & \multirow{2}{*}{$\frac{\mathrm{Q} 3}{\mathrm{Rev} .}$} & \multirow{2}{*}{$\frac{\mathrm{Q} 4}{\text { Prog }}$} & \multicolumn{2}{|c|}{ Year } \\
\hline & & & $\begin{array}{r}\text { Prog. } \\
\text { (IMF CR } \\
\text { No. } 05 / 132 \text { ) }\end{array}$ & Act. & & & & $\begin{array}{l}\text { Prog. } \\
\text { MF CR } \\
5 / 132)\end{array}$ & Rev. Prog. \\
\hline Overall revenues and grants & 17.3 & 17.9 & 4.2 & 4.4 & 4.5 & 4.1 & 5.0 & 17.7 & 18.1 \\
\hline Total revenues & 17.0 & 17.3 & 4.2 & 4.4 & 4.1 & 4.1 & 4.7 & 17.2 & 17.3 \\
\hline Tax revenues & 15.0 & 15.2 & 3.9 & 3.9 & 3.8 & 3.9 & 4.1 & 15.7 & 15.7 \\
\hline Income and profit tax & 1.6 & 1.7 & 0.4 & 0.5 & 0.5 & 0.5 & 0.5 & 1.9 & 2.0 \\
\hline Payroll taxes & 1.8 & 1.9 & 0.5 & 0.5 & 0.5 & 0.6 & 0.5 & 2.0 & 2.0 \\
\hline Property taxes & 0.6 & 0.6 & 0.1 & 0.2 & 0.1 & 0.2 & 0.2 & 0.6 & 0.6 \\
\hline Internal taxes on goods and services & 7.5 & 7.8 & 1.9 & 2.1 & 2.0 & 2.0 & 2.1 & 7.9 & 8.2 \\
\hline VAT & 5.2 & 5.7 & 1.3 & 1.6 & 1.4 & 1.5 & 1.6 & 5.7 & 6.0 \\
\hline Excises and other internal indirect taxes & 2.3 & 2.2 & 0.5 & 0.5 & 0.6 & 0.5 & 0.5 & 2.2 & 2.2 \\
\hline International trade and operations tax & 3.4 & 3.0 & 0.9 & 0.7 & 0.7 & 0.6 & 0.8 & 3.1 & 2.9 \\
\hline Sales taxes & 1.9 & 1.4 & 0.5 & 0.3 & 0.3 & 0.3 & 0.4 & 1.5 & 1.3 \\
\hline Import duties & 1.5 & 1.6 & 0.3 & 0.4 & 0.4 & 0.4 & 0.4 & 1.6 & 1.5 \\
\hline Other taxes & 0.1 & 0.1 & 0.0 & 0.0 & 0.0 & 0.0 & 0.0 & 0.2 & 0.0 \\
\hline Nontax revenues & 2.0 & 2.1 & 0.3 & 0.5 & 0.3 & 0.3 & 0.6 & 1.5 & 1.6 \\
\hline Of which: Extra-budgetary funds & 1.1 & 1.1 & 0.2 & 0.2 & 0.2 & 0.2 & 0.1 & 0.6 & 0.6 \\
\hline Grants & 0.3 & 0.7 & 0.0 & 0.0 & 0.4 & 0.0 & 0.4 & 0.5 & 0.7 \\
\hline Total expenditures and lending minus repayments & 19.1 & 20.3 & 4.8 & 4.3 & 6.3 & 5.7 & 5.8 & 22.2 & 22.2 \\
\hline Current expenditures & 12.6 & 12.1 & 3.4 & 3.0 & 3.9 & 3.6 & 3.7 & 14.1 & 14.1 \\
\hline Expenditures on goods and services & 8.3 & 8.4 & 2.3 & 1.9 & 2.8 & 2.6 & 2.2 & 9.5 & 9.5 \\
\hline Wages and salaries & 2.8 & 2.7 & 0.9 & 0.8 & 1.0 & 1.1 & 1.1 & 3.9 & 3.9 \\
\hline Others & 5.5 & 5.6 & 1.4 & 1.2 & 1.8 & 1.5 & 1.1 & 5.6 & 5.6 \\
\hline Interest payments & 1.2 & 0.7 & 0.1 & 0.1 & 0.2 & 0.2 & 0.4 & 0.8 & 0.8 \\
\hline External & 0.7 & 0.4 & 0.1 & 0.1 & 0.1 & 0.1 & 0.2 & 0.4 & 0.4 \\
\hline Domestic & 0.5 & 0.3 & 0.1 & 0.0 & 0.1 & 0.1 & 0.2 & 0.4 & 0.4 \\
\hline Transfers and subsidies & 3.0 & 3.1 & 0.9 & 1.0 & 0.9 & 0.9 & 1.1 & 3.8 & 3.8 \\
\hline Capital expenditures & 6.5 & 8.1 & 1.4 & 1.6 & 2.4 & 2.1 & 1.9 & 8.1 & 8.0 \\
\hline Externally financed PIP & 2.7 & 3.1 & 1.0 & 0.8 & 1.1 & 1.1 & 1.1 & 4.0 & 4.0 \\
\hline Domestically financed & 3.8 & 5.1 & 0.4 & 0.8 & 1.4 & 1.1 & 0.8 & 4.1 & 4.0 \\
\hline Lending minus repayments & 0.0 & 0.1 & 0.0 & 0.0 & 0.0 & 0.0 & 0.0 & 0.0 & 0.0 \\
\hline Overall balance (including externally financed PIP) & -1.8 & -2.4 & -0.6 & 0.1 & -1.8 & -1.6 & -0.8 & -4.5 & -4.1 \\
\hline Overall balance (excluding externally financed PIP) & 0.9 & 0.7 & 0.4 & 0.9 & -0.8 & -0.5 & 0.3 & -0.5 & -0.1 \\
\hline Total financing (including externally financed PIP) & 1.8 & 2.4 & 0.6 & -0.1 & 1.8 & 1.6 & 0.8 & 4.5 & 4.1 \\
\hline Net external & 2.8 & 4.0 & 0.7 & 0.5 & 0.9 & 0.9 & 0.8 & 3.7 & 3.2 \\
\hline Disbursements & 2.7 & 4.3 & 1.0 & 1.0 & 1.1 & 1.1 & 1.1 & 4.4 & 4.3 \\
\hline Program loans & 0.0 & 1.3 & 0.0 & 0.2 & 0.0 & 0.0 & 0.0 & 0.4 & 0.3 \\
\hline Project loans & 2.7 & 3.1 & 1.0 & 0.8 & 1.1 & 1.1 & 1.1 & 4.0 & 4.0 \\
\hline Amortization & -0.3 & -0.3 & -0.3 & -0.5 & -0.2 & -0.1 & -0.2 & -0.7 & -1.0 \\
\hline Drawdown of Tajikistan's claim on CBR & 0.5 & 0.0 & 0.0 & 0.0 & 0.0 & 0.0 & 0.0 & 0.0 & 0.0 \\
\hline Net domestic & -1.1 & -1.7 & -0.1 & -0.6 & 0.9 & 0.6 & -0.1 & 0.7 & 0.9 \\
\hline NBT $1 /$ & -1.3 & -1.9 & -0.2 & -0.6 & 0.7 & 0.6 & -0.1 & 0.4 & 0.5 \\
\hline Commercial banks & -0.2 & -0.1 & 0.0 & -0.1 & 0.1 & 0.0 & 0.0 & 0.0 & 0.1 \\
\hline Gross proceeds from privatization & 0.5 & 0.4 & 0.1 & 0.1 & 0.1 & 0.1 & 0.1 & 0.3 & 0.3 \\
\hline \multicolumn{10}{|l|}{ Memorandum items: } \\
\hline Nominal GDP (in millions of somoni) & 4,758 & 6,158 & 7,100 & 7,100 & 7,100 & 7,100 & 7,100 & 7,100 & 7,100 \\
\hline
\end{tabular}

Sources: Tajik authorities; and Fund staff estimates.

1/ Differences between the historical financing figures and those in the NBT accounts are due to the inclusion of undisbursed project financing in the NBT's accounts with government. Also, the historical financing figures in this table are based on estimated flows, not differences between end-period stocks. 


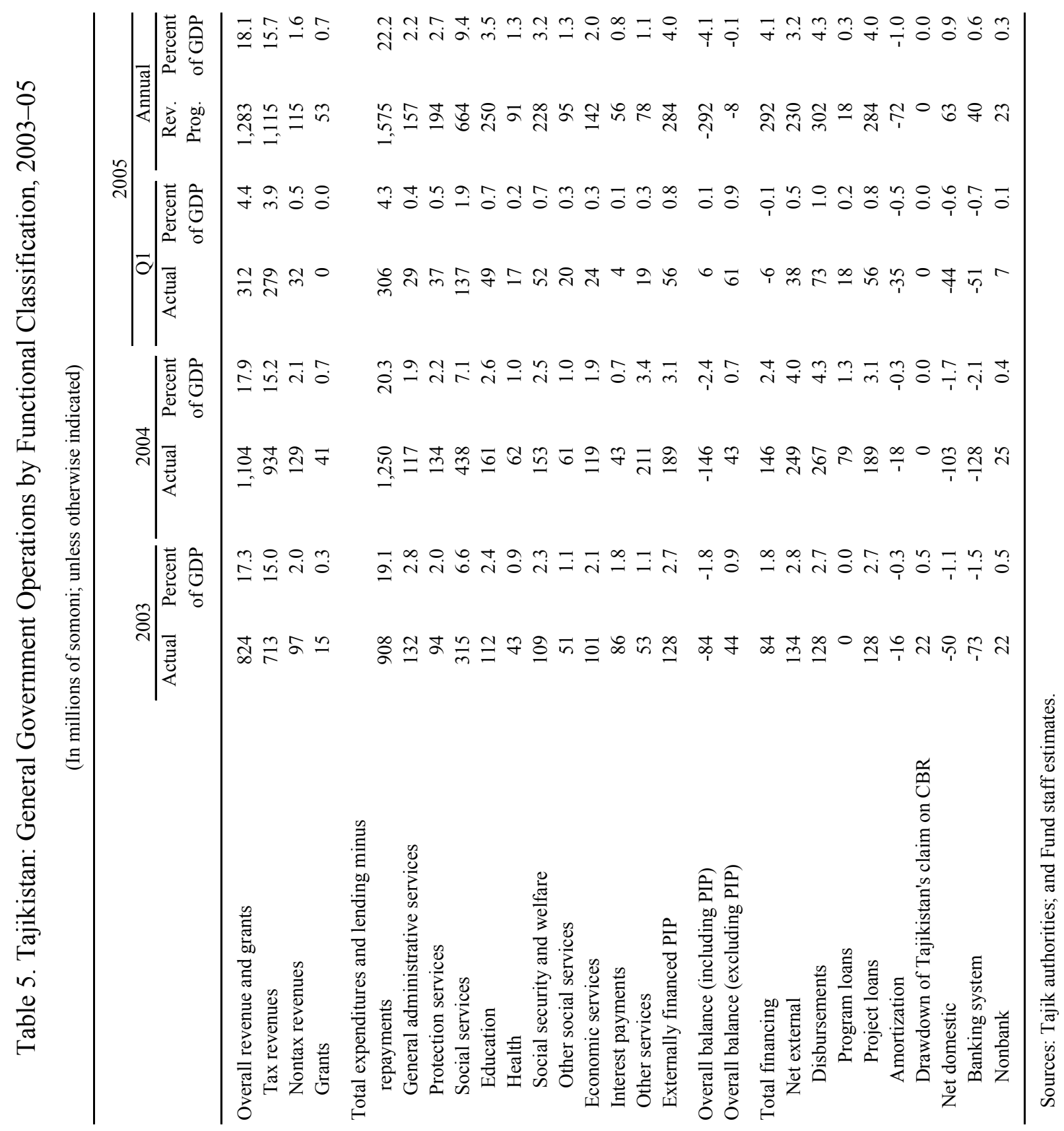




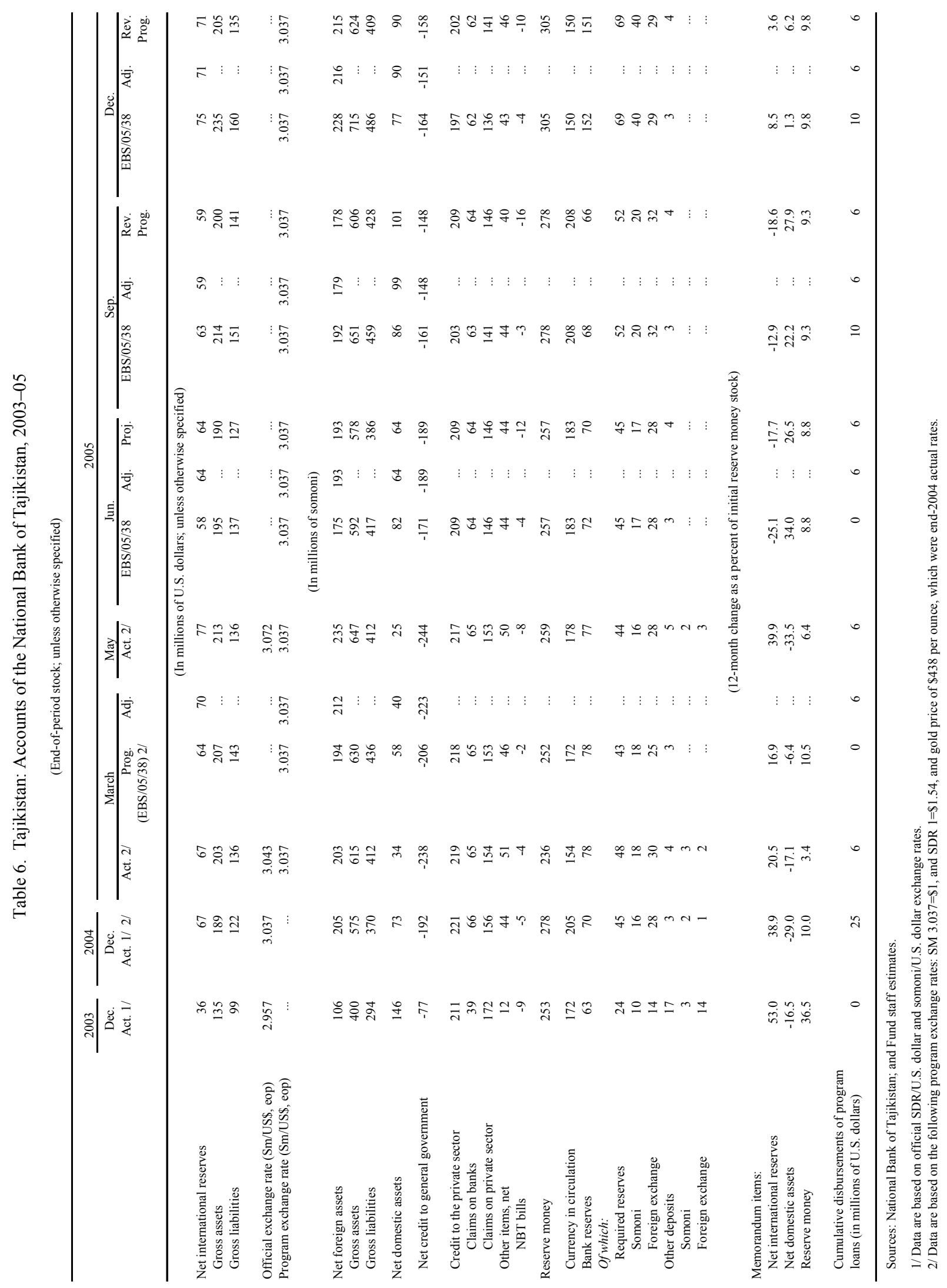




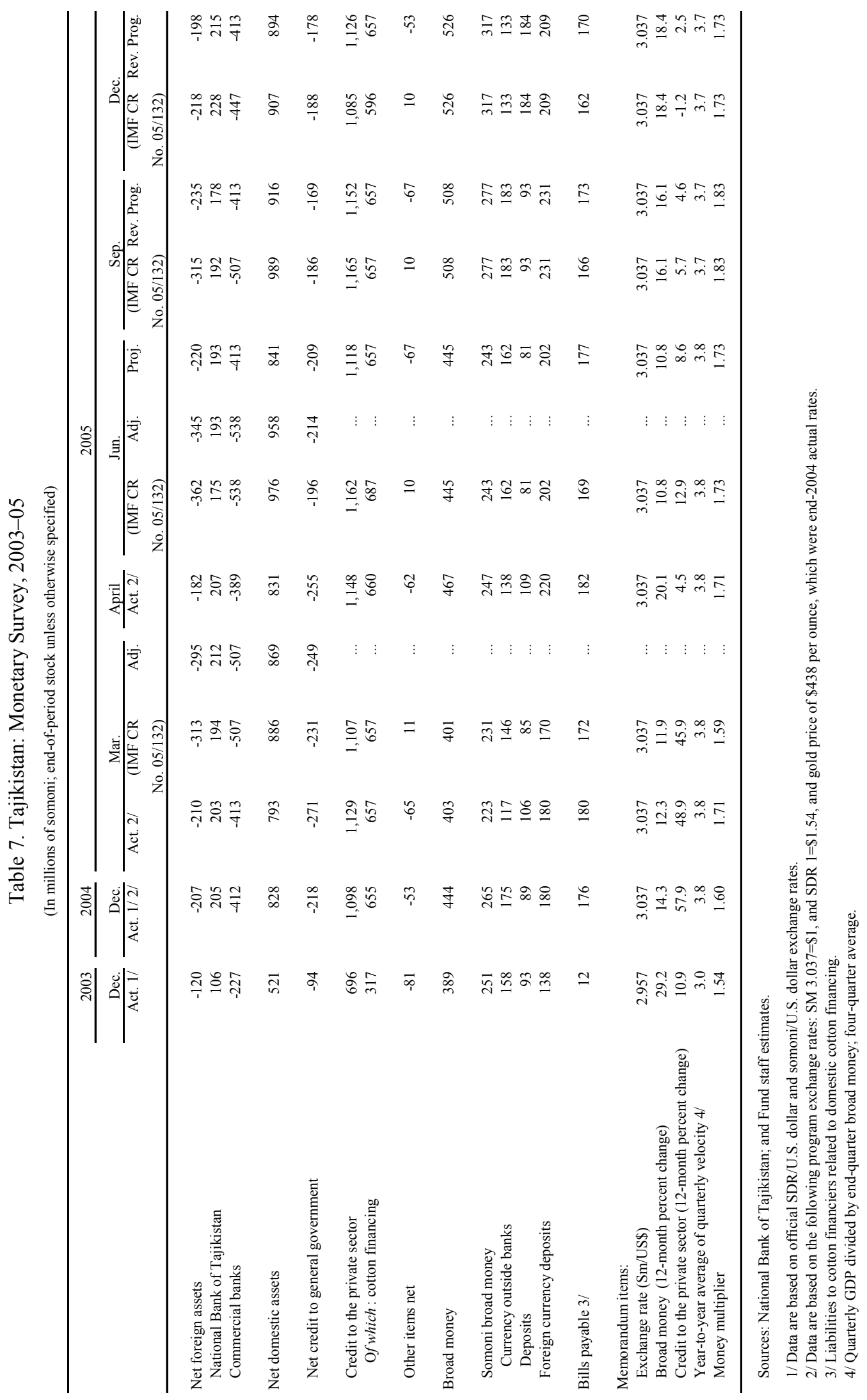


Table 8. Tajikistan: Balance of Payments, 2003-05

(In millions of U.S. dollars)

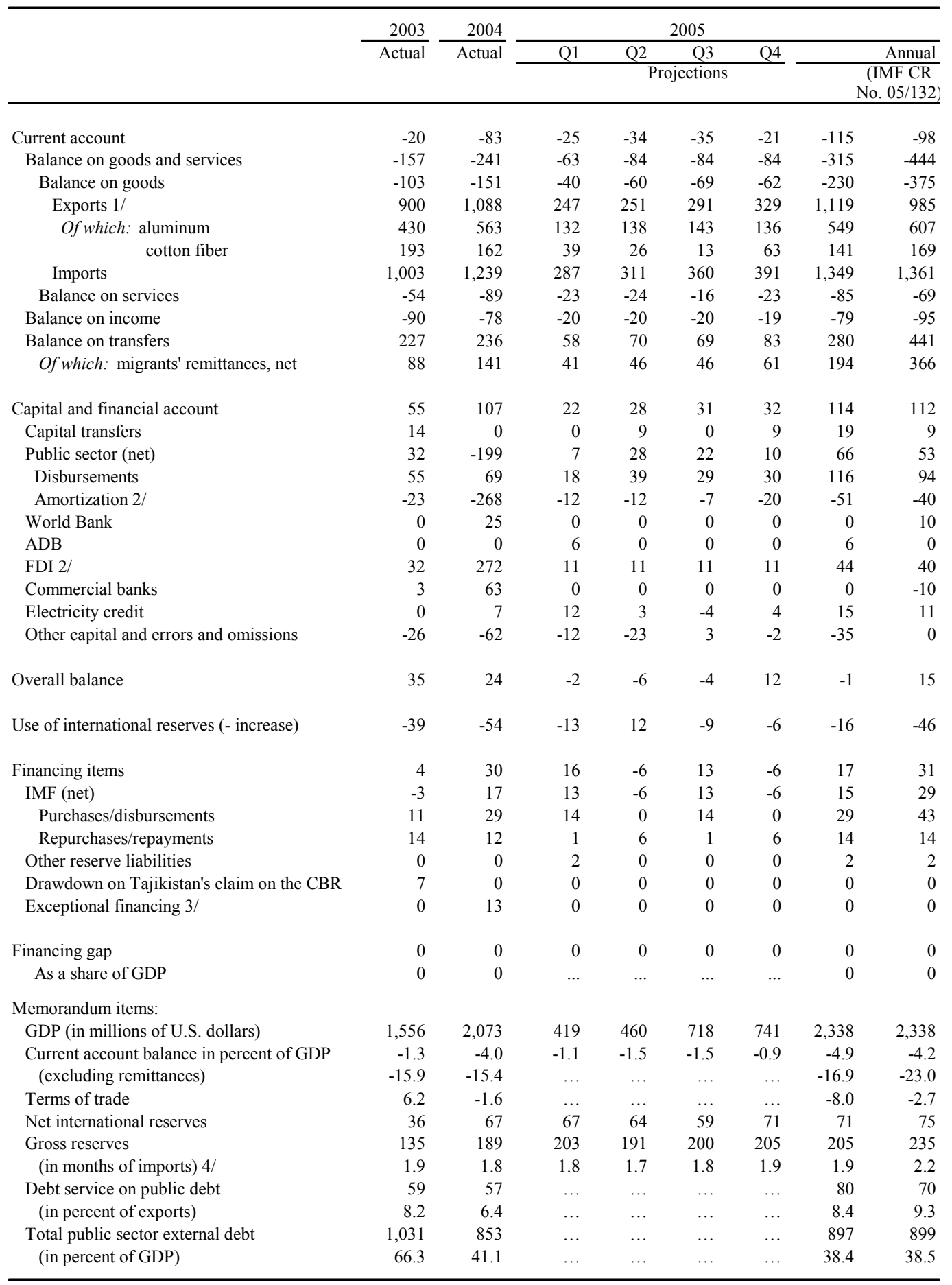

Sources: Tajik authorities; and Fund staff estimates.

1/ Includes small export receipts which were previously classified as remittances.

2/ In Q4 2004 includes debt-for-equity swap with Russia.

3/ Debt cancellation by Pakistan.

4/ Excluding trade in alumina and electricity, which are on barter basis. 
Table 9. Tajikistan: Medium-Term Balance of Payments, 2003-10

(In millions of U.S. dollars)

\begin{tabular}{|c|c|c|c|c|c|c|c|c|}
\hline & 2003 & 2004 & 2005 & 2006 & 2007 & 2008 & 2009 & 2010 \\
\hline & Actual & Actual & \multicolumn{6}{|c|}{ Projections } \\
\hline Current account & -20 & -83 & -115 & -110 & -119 & -123 & -135 & -141 \\
\hline Balance on goods and services & -157 & -241 & -315 & -315 & -339 & -359 & -390 & -418 \\
\hline Balance on goods & -103 & -151 & -230 & -222 & -239 & -245 & -263 & -281 \\
\hline Exports 1/ & 900 & 1,088 & 1,119 & 1,212 & 1,286 & 1,424 & 1,564 & 1,724 \\
\hline Of which: aluminum & 430 & 563 & 549 & 567 & 561 & 589 & 618 & 649 \\
\hline cotton fiber & 193 & 162 & 141 & 121 & 126 & 134 & 138 & 143 \\
\hline Imports & 1,003 & 1,239 & 1,349 & 1,433 & 1,525 & 1,669 & 1,826 & 2,005 \\
\hline Balance on services & -54 & -89 & -85 & -93 & -100 & -113 & -127 & -138 \\
\hline Balance on income & -90 & -78 & -79 & -87 & -89 & -94 & -101 & -108 \\
\hline Balance on transfers & 227 & 236 & 280 & 292 & 309 & 330 & 355 & 385 \\
\hline Of which: migrants' remittances & 88 & 141 & 194 & 217 & 243 & 271 & 301 & 334 \\
\hline Capital and financial account & 55 & 107 & 114 & 149 & 145 & 158 & 181 & 194 \\
\hline Capital transfers & 14 & 0 & 19 & 0 & 0 & 0 & 0 & 0 \\
\hline Public sector (net) & 32 & -199 & 66 & 71 & 85 & 93 & 117 & 125 \\
\hline Disbursements & 55 & 69 & 116 & 107 & 124 & 134 & 145 & 157 \\
\hline Amortization 2/ & -23 & -268 & -51 & -36 & -39 & -41 & -28 & -32 \\
\hline World Bank & 0 & 25 & 0 & 10 & 0 & 0 & 0 & 0 \\
\hline $\mathrm{ADB}$ & 0 & 0 & 6 & 0 & 0 & 0 & 0 & 0 \\
\hline FDI & 32 & 272 & 44 & 79 & 70 & 74 & 73 & 77 \\
\hline Commercial bank NFA (- increase) & 3 & 63 & 0 & -11 & -10 & -9 & -8 & -7 \\
\hline Electricity credit & 0 & 7 & 15 & 0 & 0 & 0 & 0 & 0 \\
\hline Other capital and errors and omissions & -26 & -62 & -35 & 0 & 0 & 0 & 0 & 0 \\
\hline Overall balance & 35 & 24 & -1 & 39 & 26 & 36 & 46 & 53 \\
\hline Use of international reserves (- increase) & -39 & -54 & -16 & -48 & -30 & -40 & -40 & -40 \\
\hline Financing items & 4 & 30 & 17 & -1 & -16 & -16 & -10 & -14 \\
\hline IMF (net) & -3 & 17 & 15 & -1 & -16 & -16 & -10 & -14 \\
\hline Purchases/disbursements & 11 & 29 & 29 & 15 & 0 & 0 & 0 & 0 \\
\hline Repurchases/repayments & 14 & 12 & 14 & 16 & 16 & 16 & 10 & 14 \\
\hline Other reserve liabilities & 0 & 0 & 2 & 0 & 0 & 0 & 0 & 0 \\
\hline Drawdown on Tajikistan's claim on the CBR & 7 & 0 & 0 & 0 & 0 & 0 & 0 & 0 \\
\hline Exceptional financing 3/ & 0 & 13 & 0 & 0 & 0 & 0 & 0 & 0 \\
\hline Financing gap & 0 & 0 & 0 & 10 & 20 & 20 & 4 & 1 \\
\hline As a share of GDP & 0 & 0 & 0 & 0 & 1 & 1 & 0 & 0 \\
\hline \multicolumn{9}{|l|}{ Memorandum items: } \\
\hline Current account balance in percent of GDP & -1.3 & -4.0 & -4.9 & -4.3 & -4.3 & -4.1 & -4.2 & -4.1 \\
\hline (excluding transfers) & -15.9 & -15.4 & -16.9 & -15.8 & -15.5 & -15.2 & -15.2 & -15.1 \\
\hline Terms of trade (g\&s) & 6.2 & -1.6 & -8.0 & -0.5 & -0.4 & 0.1 & -0.8 & -0.6 \\
\hline Gross reserves & 135 & 189 & 205 & 253 & 283 & 323 & 363 & 403 \\
\hline (in months of imports) 4/ & 1.9 & 1.8 & 1.9 & 2.2 & 2.2 & 2.3 & 2.3 & 2.3 \\
\hline Debt service on public debt & 59 & 57 & 80 & 68 & 72 & 75 & 59 & 67 \\
\hline (in percent of exports) & 8.2 & 6.4 & 8.4 & 6.8 & 6.8 & 6.3 & 4.4 & 4.6 \\
\hline Total public sector external debt & 1,031 & 853 & 897 & 958 & 1,008 & 1,065 & 1,148 & 1,234 \\
\hline (in percent of GDP) & 66.3 & 41.1 & 38.4 & 37.6 & 36.6 & 35.7 & 35.7 & 35.5 \\
\hline
\end{tabular}

Sources: Tajik authorities; and Fund staff estimates.

$1 /$ Includes small export receipts which were previously classified as remittances.

2/ In Q4 2004 includes debt-for-equity swap with Russia.

3/ Debt cancellation by Pakistan.

4/ Excluding trade in alumina and electricity, which are on barter basis. 
Table 10. Tajikistan: Medium-Term Macroeconomic Projections, 2003-07

\begin{tabular}{|c|c|c|c|c|c|}
\hline & & & 2005 & 2006 & 2007 \\
\hline & 2003 & 2004 & \multicolumn{3}{|c|}{ Projections } \\
\hline \multicolumn{6}{|l|}{ National income and prices } \\
\hline Nominal GDP (in millions of somoni) & 4,758 & 6,158 & 7,100 & 7,977 & 8,882 \\
\hline Nominal GDP (in millions of U.S. dollars) & 1,556 & 2,073 & 2,338 & 2,550 & 2,757 \\
\hline Real GDP (annual percent change) & 10.2 & 10.6 & 8.0 & 7.0 & 6.0 \\
\hline GDP per capita (in U.S. dollars) & 236 & 310 & 344 & 370 & 394 \\
\hline GDP deflator (annual percent change) & 29.1 & 17.0 & 6.7 & 5.0 & 5.0 \\
\hline Consumer prices (12-month percent change, e.o.p.) & 13.7 & 5.6 & 7.0 & 5.0 & 5.0 \\
\hline Consumer prices (year-on-year percent change, average) & 16.4 & 7.1 & 7.2 & 5.0 & 5.0 \\
\hline & \multicolumn{5}{|c|}{ (In percent of GDP) } \\
\hline \multicolumn{6}{|l|}{ General government finances } \\
\hline Total revenue and grants & 17.3 & 17.9 & 18.1 & 17.8 & 17.9 \\
\hline \multicolumn{6}{|l|}{ Of which: } \\
\hline Tax revenue & 15.0 & 15.2 & 15.7 & 16.2 & 16.4 \\
\hline Total expenditure & 19.1 & 20.3 & 22.2 & 22.5 & 22.9 \\
\hline \multicolumn{6}{|l|}{ Of which: } \\
\hline Current expenditure & 12.6 & 12.1 & 14.1 & 13.8 & 14.0 \\
\hline Fiscal balance (excluding the PIP) & 0.9 & 0.7 & -0.1 & -0.5 & -0.5 \\
\hline Public investment program (PIP) & 2.7 & 3.1 & 4.0 & 4.2 & 4.5 \\
\hline \multicolumn{6}{|l|}{ Savings/investment balances } \\
\hline External current account balance & -1.3 & -4.0 & -4.9 & -4.3 & -4.3 \\
\hline Overall fiscal balance (including the PIP) & -1.8 & -2.4 & -4.1 & -4.7 & -5.0 \\
\hline \multirow[t]{2}{*}{ Net savings (S-I) of the private sector $1 /$} & 0.4 & -1.6 & -0.8 & 0.4 & 0.7 \\
\hline & \multicolumn{5}{|c|}{ (In millions of U.S. dollars; unless otherwise specified) } \\
\hline \multicolumn{6}{|l|}{ External sector } \\
\hline Exports of goods & 900 & 1,088 & 1,119 & 1,212 & 1,286 \\
\hline Imports of goods & 1,003 & 1,239 & 1,349 & 1,433 & 1,525 \\
\hline Current account balance & -20 & -83 & -115 & -110 & -119 \\
\hline Gross international reserves & 135 & 189 & 205 & 253 & 283 \\
\hline Gross international reserves (in months of imports) & 1.9 & 1.8 & 1.9 & 2.2 & 2.2 \\
\hline
\end{tabular}

Sources: Tajik authorities; and Fund staff estimates.

1/ Defined as the external current account balance less the overall fiscal balance (including the PIP). 


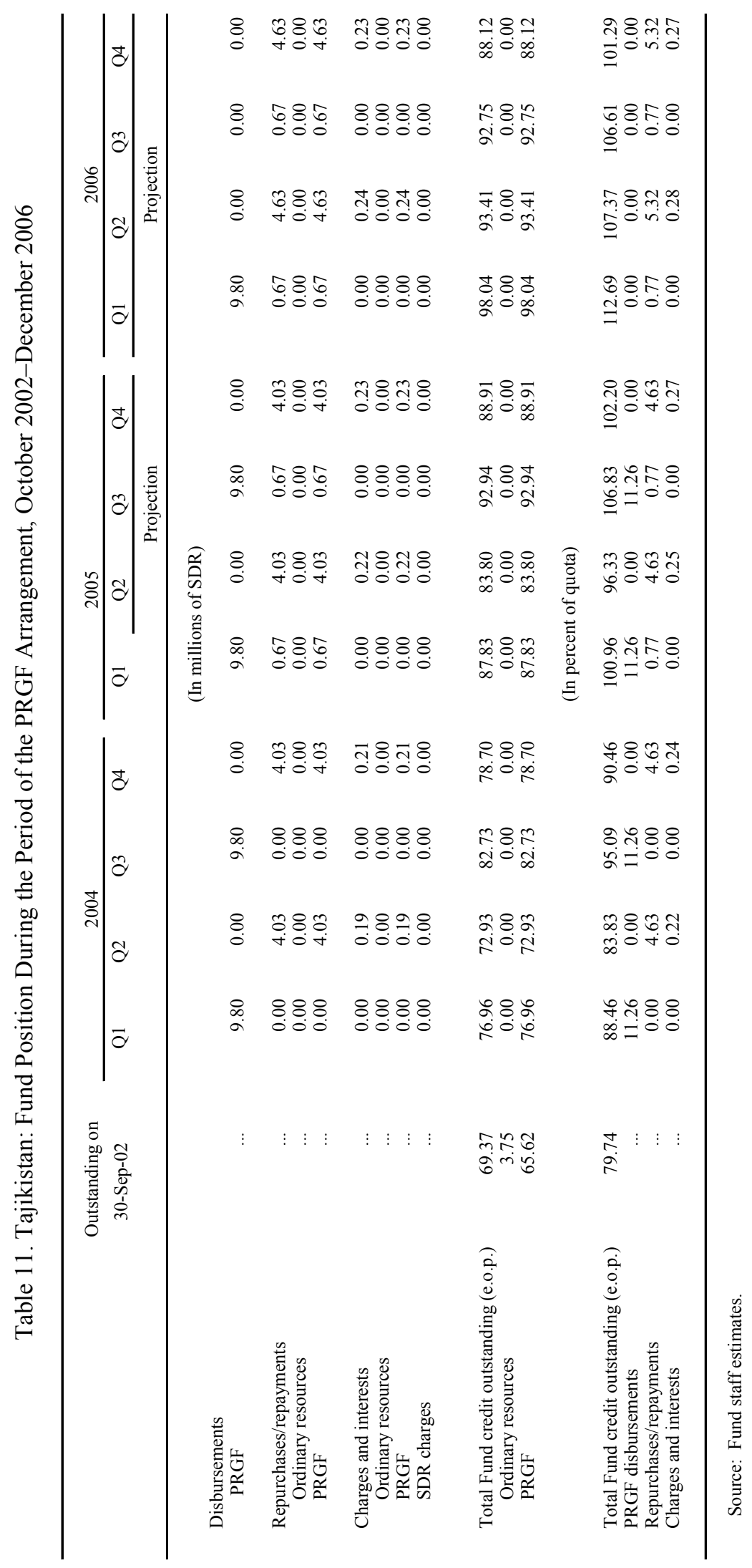


Table 12. Tajikistan: Reviews and Disbursements Under the Three-Year PRGF Arrangement, 2002-05

\begin{tabular}{|c|c|c|}
\hline Date & Action/Status & Disbursement \\
\hline December 11, 2002 & Board approval of a three-year arrangement. & SDR 8 million \\
\hline July 18,2003 & Completed first review based on end-March 2003 performance criteria. & SDR 8 million \\
\hline January 16, 2004 & $\begin{array}{l}\text { Completed second review based on end-September } 2003 \text { performance } \\
\text { criteria, and adopted conditions and disbursements for the second year of } \\
\text { the arrangement. }\end{array}$ & SDR 9.8 million \\
\hline July 21, 2004 & Completed third review based on end-March 2004 performance criteria. & SDR 9.8 million \\
\hline March 18, 2005 & $\begin{array}{l}\text { Completed fourth review based on end-September } 2004 \text { performance } \\
\text { criteria, and adopted conditions and disbursements for the third year of the } \\
\text { arrangement. }\end{array}$ & SDR 9.8 million \\
\hline July 25,2005 & Complete fifth review based on end-March 2005 performance criteria. & SDR 9.8 million \\
\hline February 10, 2006 & Complete sixth review based on end-September 2005 performance criteria. & SDR 9.8 million \\
\hline
\end{tabular}


Table 13. Tajikistan: Millennium Development Goals, 1990-2015 1/

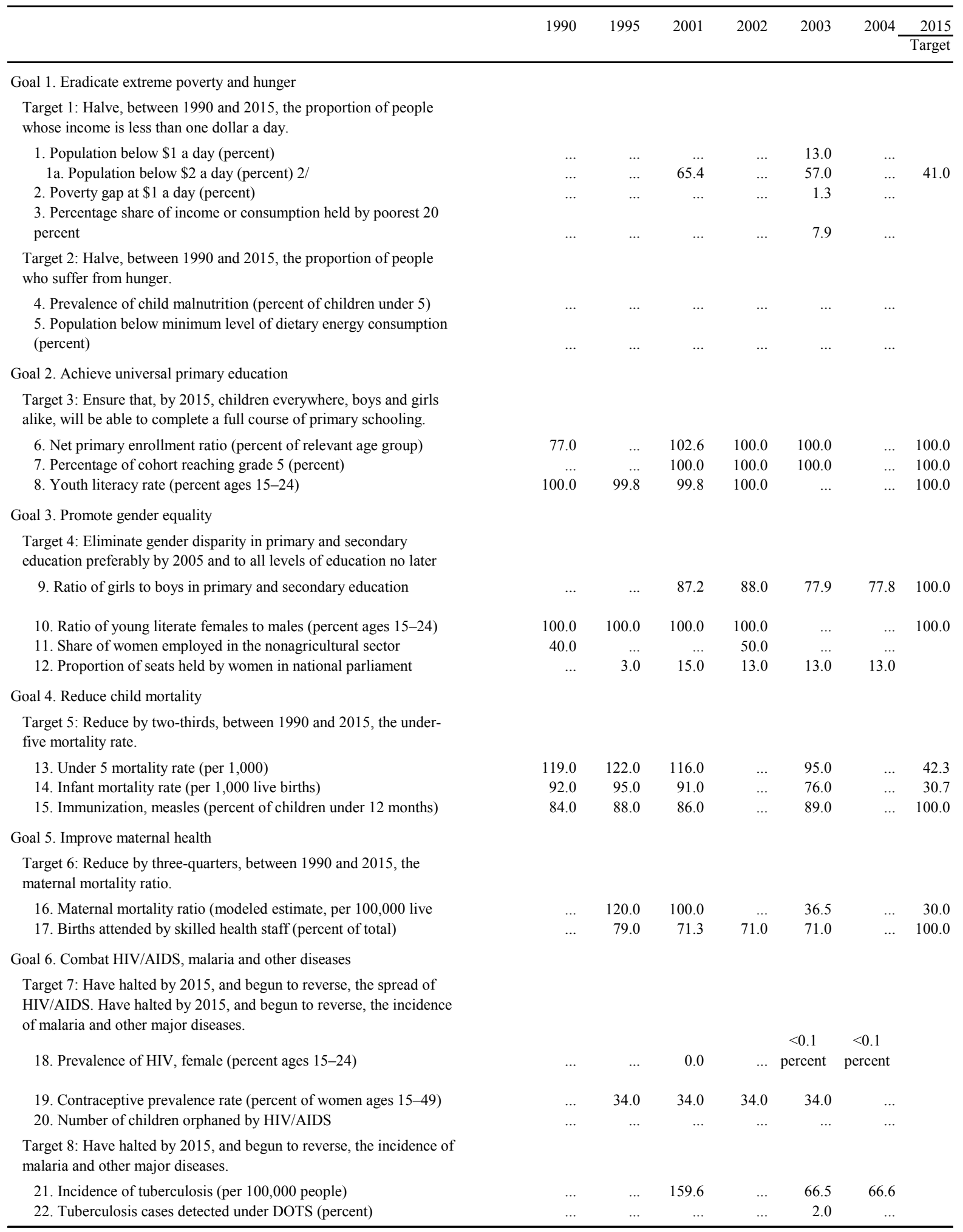


Table 13. Tajikistan: Millennium Development Goals, 1990-2015 (Continued)

\begin{tabular}{|c|c|c|c|c|c|c|c|}
\hline & 1990 & 1995 & 2001 & 2002 & 2003 & 2004 & $\frac{2015}{\text { Target }}$ \\
\hline \multicolumn{8}{|l|}{ Goal 7. Ensure environmental sustainability } \\
\hline \multicolumn{8}{|l|}{$\begin{array}{l}\text { Target 9: Integrate the principles of sustainable development into } \\
\text { country policies and programs and reverse the loss of environmental } \\
\text { resources. }\end{array}$} \\
\hline 23. Forest area (percent of total land area) & 2.7 & $\ldots$ & 2.8 & $\ldots$ & $\ldots$ & $\ldots$ & \\
\hline 24. Nationally protected areas (percent of total land area) & $\ldots$ & 4.2 & 4.2 & 4.2 & 4.2 & $\ldots$ & \\
\hline 25. GDP per unit of energy use (PPP \$ per kg oil equivalent) & 0.8 & 1.4 & 1.7 & 1.9 & $\cdots$ & $\cdots$ & \\
\hline 26. $\mathrm{CO} 2$ emissions (metric tons per capita) & 3.7 & 0.9 & 0.8 & $\ldots$ & $\cdots$ & $\ldots$ & \\
\hline \multicolumn{8}{|l|}{$\begin{array}{l}\text { Target } 10 \text { : Halve, by } 2015 \text {, the proportion of people without } \\
\text { sustainable access to safe drinking water. }\end{array}$} \\
\hline 27. Access to an improved water source (percent of population) & $\cdots$ & $\cdots$ & 58.0 & 58.0 & $\cdots$ & $\cdots$ & \\
\hline \multicolumn{8}{|l|}{$\begin{array}{l}\text { Target } 11 \text {. Achieve by } 2020 \text { significant improvement for at least } 100 \\
\text { million slum dwellers. }\end{array}$} \\
\hline 28. Access to improved sanitation (percent of population) & $\cdots$ & $\cdots$ & $\cdots$ & 53.0 & $\cdots$ & $\cdots$ & \\
\hline 29. Access to secure tenure (percent of population) & $\cdots$ & $\cdots$ & $\cdots$ & $\cdots$ & $\cdots$ & $\cdots$ & \\
\hline \multicolumn{8}{|l|}{ Goal 8. Develop a Global Partnership for Development } \\
\hline \multicolumn{8}{|l|}{$\begin{array}{l}\text { Target 12: Develop and implement strategies for decent and } \\
\text { productive work for youth. }\end{array}$} \\
\hline $\begin{array}{l}\text { 30. Youth unemployment rate (percent of total labor force ages } \\
15-24)\end{array}$ & $\cdots$ & $\cdots$ & $\cdots$ & $\cdots$ & $\cdots$ & $\cdots$ & \\
\hline \multicolumn{8}{|l|}{$\begin{array}{l}\text { Target 12: Develop further an open, rule-based, predictable, non- } \\
\text { discriminatory trading and financial system. Address the Special } \\
\text { Needs of the Least Developed Countries. Address the Special Needs } \\
\text { of landlocked countries and small island developing states. }\end{array}$} \\
\hline 32. Fixed line and mobile telephones (per 1,000 people) & 45.0 & 41.6 & 36.2 & $\ldots$ & 45.0 & 62.5 & \\
\hline 33. Personal computers (per 1,000 people) & $\ldots$ & $\ldots$ & $\ldots$ & $\ldots$ & $\ldots$ & $\ldots$ & \\
\hline $\begin{array}{l}\text { 33a. Internet users (per } 1,000 \text { people) } \\
\text { 34. General indicators }\end{array}$ & $\ldots$ & $\ldots$ & $\ldots$ & $\ldots$ & 0.1 & 0.4 & \\
\hline 35. Population (In millions) & 5.3 & 5.8 & 6.2 & 6.3 & 6.5 & 6.5 & \\
\hline 36. Gross national income (in billions of \$'s) & 4.5 & 2.3 & 1.1 & 1.2 & 1.6 & $\ldots$ & \\
\hline 37. GNI per capita (In \$'s) & 840.0 & 390.0 & 180.0 & 180.0 & 350.0 & $\ldots$ & \\
\hline 38. Adult literacy rate (percent of people ages 15 and over) & 98.2 & 98.8 & 99.3 & 99.3 & $\ldots$ & $\ldots$ & \\
\hline 39. Total fertility rate (births per woman) & 5.1 & 3.7 & 3.0 & 2.9 & $\ldots$ & $\ldots$ & \\
\hline 40. Life expectancy at birth (years) & 69.3 & 68.3 & 66.9 & 66.6 & $\ldots$ & $\ldots$ & \\
\hline 41. Aid (percent of GNI) & 0.5 & 2.9 & 15.5 & $\ldots$ & $\ldots$ & $\ldots$ & \\
\hline 42. External debt (percent of GNI) & 0.4 & 28.2 & 105.9 & $\ldots$ & $\ldots$ & $\ldots$ & \\
\hline 43. Investment (percent of GDP) & 24.8 & 28.7 & 16.7 & 13.9 & 13.1 & 14.9 & \\
\hline 44. Trade (percent of GDP) & 63.0 & 143.4 & 139.6 & 132.4 & 122.3 & 112.2 & \\
\hline
\end{tabular}

Sources: World Development Indicators; World Bank.

$1 /$ In some cases the data are for earlier or later years than those stated.

2/ World Bank estimate for 1999; based on purchasing power parity expenditure level of $\$ 2.15$ per day. Preliminary estimates indicate that poverty declined to 57 percent in 2003 . 


\section{TAJIKISTAN: FUND RELATIONS}

(As of May 31, 2005)

I. Membership Status: Joined April 27, 1993; Article VIII

II. General Resources Account:

Quota

Fund holdings of currency

Reserve position in Fund

$\begin{array}{rrr}\text { SDR million } & & \text { \% Quota } \\ 87.00 & & 100.00 \\ 87.00 & & 100.00 \\ 0.00 & 0.00\end{array}$

III. SDR Department

Holdings

$\frac{\text { SDR million }}{10.03} \quad \frac{\% \text { Allocation }}{\text { N/A }}$

IV. Outstanding Purchases and Loans

PRGF arrangements

$\frac{\text { SDR million }}{87.83} \quad \frac{\text { \% Quota }}{100.96}$

V. Latest Financial Arrangements

\begin{tabular}{|c|c|c|c|c|}
\hline Type & $\begin{array}{c}\text { Approval } \\
\text { Date }\end{array}$ & $\begin{array}{l}\text { Expiration } \\
\text { Date }\end{array}$ & $\begin{array}{l}\text { Amount Approved } \\
\text { (SDR million) }\end{array}$ & $\begin{array}{l}\text { Amount Drawn } \\
\text { (SDR million) }\end{array}$ \\
\hline & Dec 11,2002 & $\operatorname{Dec} \overline{10,2005}$ & 65.00 & 45.40 \\
\hline $\mathrm{mo}$ & Jun 24, 1998 & Dec 24, 2001 & 100.30 & 78.28 \\
\hline ad-by & May 08,1996 & Dec 07, 1996 & 15.00 & 15.00 \\
\hline
\end{tabular}

VI. Projected Obligations to Fund under the Repurchase Expectations Assumptions (SDR million; based on existing use of resources and present holdings of SDRs):

\begin{tabular}{lrrrrr} 
& \multicolumn{5}{c}{ Forthcoming } \\
\cline { 2 - 6 } & $\underline{\underline{2005}}$ & $\underline{2006}$ & $\underline{2007}$ & $\underline{2008}$ & $\underline{2009}$ \\
Principal & 8.73 & 10.59 & 10.59 & 10.39 & 6.71 \\
Charges/Interest & 0.42 & 0.38 & 0.32 & 0.27 & 0.22 \\
Total & 9.14 & 10.97 & 10.92 & 10.66 & 6.93
\end{tabular}

\section{Implementation of HIPC Initiative}

Not Applicable. 


\section{Safeguards Assessment}

Under the Fund's safeguards assessment policy, the NBT is subject to a full safeguards assessment with respect to the PRGF arrangement approved on December 11, 2002. The assessment was completed on July 23, 2003, and included specific measures to address a number of weaknesses, mainly in the areas of financial accounting and reporting and auditing procedures. The NBT is implementing the recommendations of the safeguards assessment, albeit with some delay compared to the original schedule due to capacity constraints. These measures are being monitored by staff under the current PRGF arrangement.

\section{Exchange Rate Arrangements}

The NBT maintains a managed floating exchange rate regime with no pre-announced path for the exchange rate. On August 12, 2002, the NBT revised the calculation of the official exchange rate to include all interbank transactions in foreign exchange. Since November 2001, the authorities have been setting the official exchange rate once a week based on a weighted average of exchange rates in the official interbank market.

With effect from December 9, 2004, the Republic of Tajikistan accepted the obligations of Article VIII, Sections 2, 3, and 4 of the Articles of Agreement. As a result, the Republic of Tajikistan maintains an exchange system that is free of restrictions on the making of payments and transfers for current international transactions, except for exchange restrictions maintained for security reasons that have been notified to the Fund pursuant to Executive Board decision No. 144-(52/51).

\section{Article IV Consultation}

The 2004 Article IV consultation was completed in March 2005. Tajikistan is on the 24-month consultation cycle, subject to the provisions of the decision on consultation cycles approved on July 15, 2002.

\section{Resident Representative}

Mr. Khawaja, Resident Representative of the Fund, started his assignment in Dushanbe in March 2003.

\section{Resident Advisors}

A resident debt management expert, financed by the Swiss Secretariat for Economic Affairs, began his assignment in May 2003 and finished at end 2004. 


\section{Technical Assistance}

The following list summarizes the technical assistance provided by the Fund to Tajikistan since 2002.

\section{Fiscal Affairs:}

August 2002

Tax Policy and Administration

July 2004

Revenue Administration Reform

December 2004

Poverty and Social Impact Analysis

June 2005

Public Financial Management

Monetary and Financial Systems:

July 2002

Multi-topic

Statistics:

March 2002

Balance of Payments Statistics

October/November 2002 Money and Banking Statistics

January 2003

Balance of Payments Statistics

February 2003

Money and Banking Statistics

May 2003

Balance of Payments Statistics

April 2004

Data ROSC

October 2004

General Data Dissemination System (GDDS)

\section{Finance:}

May 2003

Safeguards Assessment Follow-up

\section{Legal:}

March 2003

Tax Legislation

January 2004

Tax Legislation

May 2004

Tax Legislation 


\section{TAJIKISTAN: RELATIONS WITH THE WORLD BANK}

(As of June 27, 2005)

Country Director: Mr. Dennis N. de Tray

Telephone: (202) 4733544

\section{A. Partnership in Tajikistan's Development Strategy}

1. The government's poverty reduction strategy, embodied in its first full PRSP, was endorsed by the IDA and IMF Boards in December 2002. The strategy comprises four elements: sustainable growth, improved governance, better provision of basic social services, and targeted support for the poor. While the PRSP's overall direction was considered appropriate by the IMF and IDA Boards, lack of prioritization was identified as a major weakness. The Country Assistance Strategy, approved by the Bank's Board of Executive Directors on February 27, 2003, recognizes this concern by emphasizing selectivity.

2. Macroeconomic management aims at establishing a stable economic environment through appropriate fiscal, monetary, exchange rate, and sustainable debt policies. In support of these policies, the authorities are tightening payment discipline, especially in the energy sector, hardening budget constraints for state-owned enterprises, and pursuing enterprise and banking privatization and restructuring. Recent improvements in macroeconomic management have supported the current economic recovery, although maintaining strong growth will depend importantly on accelerating structural reform to enhance private sector development, and to encourage foreign and domestic investment.

3. The IMF has taken the lead in assisting Tajikistan in enhancing macroeconomic stability. In this regard, the Fund has encouraged the authorities to continue with fiscal consolidation, to maintain a restrictive monetary policy stance, and to restructure external debt to reduce the heavy burden and to enhance debt sustainability. The Fund has supported Tajikistan's economic reform program since 1996. During January-June 2002, the authorities successfully implemented a Staff Monitored Program, which formed the basis of a new Fund-supported program under the PRGF, approved by the Executive Board in December 2002. The program covers the period October 1, 2002-September 30, 2005 and its fourth review was completed on March 18, 2005.

4. The World Bank has taken the lead in the policy dialogue on structural issues, including poverty reduction measures, agriculture sector reforms, private sector development, institution building, and governance. A range of instruments is used to conduct the dialogue. Policy based lending is supporting a multisectoral structural reform agenda, supported by technical assistance as appropriate. The second tranche of SAC2 was disbursed in summer 2004 and the Second Institution Building Technical Assistance Credit will close shortly. The Policy Based Credit currently under preparation will engage the government in the areas of public sector reform in close coordination with the IMF, private sector development, and trade and transport. This broad-based approach is combined with sector projects in rural infrastructure and power, agriculture, environment, health, education, and poverty alleviation. The Country Procurement Assessment Review, the Country Financial 
Accountability Assessment, and the Public Expenditure and Institutional Review have been finalized in collaboration with the Government of Tajikistan. A Trade Diagnostic Study, and an Investment Climate Assessment are being finalized. Additionally, a new Poverty Assessment Report and a health sector note have been prepared. The health sector note identifies priority areas for reform of the health sector, a much needed strengthening of primary health care in particular.

\section{Tajikistan: Collaboration of the World Bank and the IMF}

\begin{tabular}{|c|c|c|c|}
\hline Area & $\begin{array}{l}\text { Specialized Advice from } \\
\text { Fund }\end{array}$ & $\begin{array}{l}\text { Specialized Advice } \\
\text { from Bank }\end{array}$ & Key Instruments \\
\hline $\begin{array}{l}\text { Economic } \\
\text { Framework/ } \\
\text { Management }\end{array}$ & $\begin{array}{l}\text { Monetary policy, exchange } \\
\text { rate, fiscal, and trade } \\
\text { policies, economic statistics }\end{array}$ & $\begin{array}{l}\text { Economic growth, } \\
\text { economic statistics }\end{array}$ & $\begin{array}{l}I M F \text { : PRGF performance criteria } \\
\text { and benchmarks on monetary and } \\
\text { fiscal targets. } \\
\text { Bank: PBC under preparation. }\end{array}$ \\
\hline Budget & $\begin{array}{l}\text { Medium-term budget } \\
\text { framework, tax policy and } \\
\text { administration, customs, } \\
\text { debt management, extra } \\
\text { budgetary funds }\end{array}$ & $\begin{array}{l}\text { Budget management, } \\
\text { debt management and } \\
\text { statistics, Public } \\
\text { Expenditure Review, } \\
\text { Country Procurement } \\
\text { Assessment }\end{array}$ & $\begin{array}{l}I M F: \text { PRGF performance criteria } \\
\text { on overall fiscal balance, } \\
\text { including PIP. } \\
\text { Bank: PBC under preparation. }\end{array}$ \\
\hline $\begin{array}{l}\text { Public Sector } \\
\text { Reform }\end{array}$ & $\begin{array}{l}\text { Support to State Audit } \\
\text { Agency }\end{array}$ & $\begin{array}{l}\text { Civil service reform, } \\
\text { public sector wage } \\
\text { policy, administrative } \\
\text { restructuring and health } \\
\text { and education financing }\end{array}$ & $\begin{array}{l}I M F: \text { PRGF } \\
\text { Bank: PBC under preparation. }\end{array}$ \\
\hline Social/Poverty & & $\begin{array}{l}\text { Poverty analysis; } \\
\text { reforms in education, } \\
\text { health, social protection; } \\
\text { support to community } \\
\text { driven development }\end{array}$ & $\begin{array}{l}I M F: \text { PRGF } \\
\text { Bank: PBC under preparation. }\end{array}$ \\
\hline $\begin{array}{l}\text { Private Sector } \\
\text { Development }\end{array}$ & Bank supervision & $\begin{array}{l}\text { Pricing policies, } \\
\text { developing and } \\
\text { implementing the } \\
\text { privatization strategy, } \\
\text { farm privatization, bank } \\
\text { closure and } \\
\text { restructuring }\end{array}$ & $\begin{array}{l}I M F \text { : PRGF conditions on farm } \\
\text { privatization, bank closures. } \\
\text { Bank: PBC under preparation }\end{array}$ \\
\hline Other Sectors & & $\begin{array}{l}\text { Reforms in agriculture, } \\
\text { energy sector, water and } \\
\text { sanitation, environment, } \\
\text { infrastructure. }\end{array}$ & Bank: PBC under preparation \\
\hline
\end{tabular}

5. The next section describes the Bank program and the division of responsibility between the two institutions. In a number of areas-social sectors, environment, and infrastructure - the Bank takes the lead in the dialogue and there is no cross conditionality with the IMF-supported program. The Bank is also leading the dialogue on private sector and 
agriculture sector reform and Bank analysis serves as input into the Fund program. In other areas - energy, financial sector, public expenditure management, public sector — both institutions work together and share cross conditionality. Finally, in areas such as monetary policy, tax policy, and customs the IMF takes the lead with little Bank involvement.

\section{B. World Bank Collaboration in Specific Areas}

\section{Areas in which the World Bank leads and there is little direct IMF involvement}

6. Areas in which the Bank leads and there is no direct IMF involvement are social sectors, infrastructure and environment. In the social sphere, the Bank has carried out regular Poverty Assessments to monitor poverty and develop programs to alleviate poverty. Based on the completed Living Standards Assessment (2003), a Poverty Assessment Report has been prepared. Two Poverty Alleviation Projects have supported capacity development at the national and local level to implement participatory approaches to poverty alleviation and improve the access of the poor to essential economic and social services. In addition, the second Poverty Alleviation Project has provided support to vulnerable people through microprojects, microfinance services, and community empowerment.

7. In education, the Bank focuses on both addressing policy issues and utilizing IDA credit funds for solid investments. The ongoing Education Reform LIL and the Education Modernization Project (FY03), aim to upgrade the basic education system through:

(a) building capacity for change by involving continued support for strategic changes in curriculum and textbook production and supporting improved management and finance at the national level; and (b) supporting local initiatives for infrastructure and quality improvement, support for textbook rental schemes and book printing, and provision of equipment at the local level. The IMF has supported the education reform process, in close collaboration with the World Bank, through a structural benchmark requiring the drawing up of a fully costed education reform plan by the government.

8. In health, the Bank is focusing on: (a) rationalizing the delivery of the basic health services based on the needs of the population in selected districts, especially in remote areas where the poorest are located; (b) reform the public health services, with particular emphasis on prevention of major communicable diseases such as malaria, tuberculosis and HIV/AIDS; and (c) further strengthening the institutional capability (both at the center and district levels) to carry out health care reforms, to improve the system for budgeting and spending for basic health services, and to control outbreaks of communicable diseases and prevent HIV/AIDS epidemic from spreading. The ongoing Primary Health Care Project and the proposed Community and Basic Health Project (FY05) (under preparation) are the main instruments for the implementation of this agenda.

9. With regard to infrastructure development, the Bank is concentrating on upgrading basic utility services impacting the population at large and especially the poor. The Dushanbe Water Supply Project is helping the Dushanbe Municipality and the local water company to address the most critical deficiencies of water supply services. The Pamir Private Power Project, is supporting improvements in reliability and of electricity supply in 
the Gorno Badakshan region through private sector participation. The Rural Infrastructure Rehabilitation Project aims to increase water supply and efficiency of irrigation systems to newly privatized farms, develop institutional capacity in land and water resources management, and improve the quality of drinking water in selected villages.

10. Environment. The Bank has supported programs to improve environmental management and to deal with natural disasters. A National Environment Action Plan was developed with the Bank's help. The Emergency Flood Assistance and Lake Sarez Risk Mitigation Projects have helped the government to mitigate the consequences of frequent natural disasters and to build national capacity to increase government's preparedness to frequent natural hazards such as mudslides, rock-falls, avalanches, and seasonal floods.

\section{Areas in which the World Bank leads and its analysis serves as input into the IMF program}

11. The Bank leads the dialogue on structural reforms through the PBC currently under preparation. After initial delays, the second and final tranche of the previous SAC2 was disbursed in June 2004 after the relevant conditions had been successfully met, including conditions on privatization and the energy arrears of the aluminum smelter TadAZ. Institution building and technical assistance in support of structural reforms continue to be provided by the Education Modernization project, Land Registration and Cadastre, and the upcoming Rapid Response TA project. The Bank leads in areas of:

(i) Private Sector Development, including new measures for financial transparency and hard budget constraints, establishment of a new agency to support the private sector and improvements in the regulatory framework, and reduction of taxes on the agricultural sector. The Bank has completed the Investment Climate Review to determine the most important impediments to private sector development.

(ii) Privatization and Enterprise Reforms and Farm Privatization, including acceleration of privatization of medium and large enterprises, development of a plan to engage the private sector in Tajikistan's strategic enterprises and adoption of a strategy to privatize these enterprises in a medium term context, improvements to the corporate governance framework public enterprises; upgrading of the status of the Land Reform Committee to the equivalent of a ministry and acceleration of farm privatization and enforcement of procedures to ensure the transparency and equitable privatization of farm land; development of procedures and institutional mechanisms at the state level and selected regions to ensure fair and equitable transfer of land and other farm assets to private individuals or groups; creation of sustainable private family farming units and providing them with the enabling conditions to operate independently in a market economy. 
(iii) Regulatory Reforms, including separation of Tajik Air's organizational structure into three different business units in preparation for privatization of the airline.

12. While the Bank has taken the lead in privatization and in structural reforms in the private sector as described above, the IMF has also a strong interest in these areas since many of these reforms are critical to achieving macroeconomic stabilization and enhancing growth prospects. Accordingly, there is a high degree of consultation and coordination between the two institutions on these matters.

\section{Areas of shared responsibility}

13. The Bank and the Fund are working jointly in the following four main areas (supported by the Bank's PBC, grants, and several investment operations and the Fund's PRGF):

(i) Public Sector Management. This area includes public administration reforms aimed at redefining the role of the state in line with the market economy needs, reorganizing key ministries, strengthening the Financial Control Office responsible for audit the budget, and supporting customs administration reforms. The Bank is involved in civil service reform while the Fund is providing technical assistance in support of tax and customs administration.

(ii) Budget Planning and Execution. Both institutions work on providing support for a national Treasury, adoption of new Law on Public Finances introducing modern budgetary procedures and improved fiscal management; including Public Investment Program and switching from norm-based costing and allocation of expenditures to activity/population based in education and health sectors.

(iii) Financial Sector Reforms. This area includes the acceleration of financial sector restructuring and closure of weak banks, new regulatory framework for the establishment of nonbank intermediaries; significant changes in the tax code making tax authorities' access to bank accounts conditional on a court authorization. In terms of banking supervision, the IMF is monitoring the closure and merger of banks that do not satisfy prudential requirements.

(iv) Utilities Reform. The Fund has included in the PRGF arrangement conditionality related to energy tariff rates, energy arrears and collection rates with the aim to reduce quasi-fiscal activities and increase transparency. The Bank's program supports this objective, with a focus on enhancing market structures, improved enterprise operation, service delivery, as well as financial performance. The Bank completed an Energy Sector Utility Reform Review in 2004, which describes the financial condition of the energy sector enterprises and details the Bank's energy sector development strategy into the medium term, and expects to approve funding for the Energy Loss Reduction Project on July 6, 2005. It is also working closely together with the Asian Development Bank and the EBRD in the areas of utilities reform and restructuring of strategic enterprises such as the railways and airlines. 
Areas in which the IMF leads and its analysis serves as input into the World Bank program

14. The Fund leads the dialogue on fiscal matters, setting the overall envelope for public expenditures. The World Bank's work in key sectors, such as health, education and infrastructure, necessitates close cooperation. In addition to the achievement of overall fiscal targets, the Fund-supported PRGF includes structural benchmarks and performance criteria prohibiting the NBT from issuing directed credit, from making expenditures not related to its core business activities, and from paying dividends while it has negative net worth. This also includes finalization of an inventory of guarantees, pledges, and other contingencies of NBT.

15. In the budgetary area, the Fund is taking the lead on tax reforms and treasury systems development. The IMF also leads the dialogue on polices to rationalize and contain expenditures in the public sector. These include policies regarding wage-setting in both the public service, and defining the ceiling for public investment expenditures.

16. In these areas, the Bank takes into account the policy recommendations of the IMF and ensures that its own policy advice is consistent.

\section{Areas in which the IMF leads and there is no direct World Bank involvement}

17. The Fund takes the lead in the formulation and execution of fiscal and monetary policies, external policies, and issues involving economic and financial statistics. However, the World Bank has provided a grant $(\$ 350,000)$ financed by the Trust Fund for Statistical Capacity and Institutional Building to strengthen the National Statistics Service (Gozkomsatat). On trade issues, the Bank is finalizing a Trade Diagnostic Study which will lead to closer collaboration in this area.

\section{World Bank Group Strategy}

18. The World Bank Group Strategy and future proposed lending operations are elaborated in the CAS discussed by the Board of Directors on February 27, 2003. It focuses on three key areas which are consistent with the PRSP:

- building long-term institutions geared towards a market economy;

- $\quad$ generating growth with equity through private sector development; and

- $\quad$ addressing the pressing needs of the population through greater involvement at the local community level and support the efficient functioning of basic communal infrastructure (including schools, health facilities and other basic services).

Tajikistan is currently in the Base Case Scenario in which IDA provides up to $\$ 80$ million. This level of lending is lower than in the past due to phasing out of Tajikistan's status as a transition country in a post-conflict situation. A new CAS is under preparation and will be adopted in 2005 . 


\section{TAJIKISTAN: Relations WiTh THE ASIAN DEVELOPMENT BANK}

(As of May 26, 2005)

Country Director: Mr. Neeraj Jain Telephone: 992-372-210558/235314/235315

1. Tajikistan became a member of the Asian Development Bank (ADB) in 1998. The ADB has participated in the Consultative Group Meeting for Tajikistan since 1998. After conducting an initial mission in June 1998, ADB completed an Economic Report and Interim Operational Strategy that identified three areas: (a) agriculture; (b) infrastructure rehabilitation (especially energy and transport sectors); and (c) social sector, in which ADB assistance would have the greatest development impact. Based on the Interim Strategy, ADB's Board of Directors approved in October 1998 Tajikistan's country classification, which provides the basis for Tajikistan's full access to concessional resources (Asian Development Fund (ADF)). Based on the new ADF replenishment arrangements completed in 2004, Tajikistan is eligible for receiving 40 percent of the loan amount on grant basis after 2005.

2. In view of Tajikistan's urgent need for assistance in 1998, in coordination with the IMF and the World Bank (WB), the ADB provided a Postconflict Infrastructure Program Loan (\$20 million), which was designed to create a framework for developing market-based transport and energy sectors. The loan was for two years and was fully disbursed by end2000. Based on the satisfactory progress of the Postconflict Infrastructure Program loan conditionality, the following loans were approved in these two sectors:

- Transport Sector: the Road Rehabilitation Project loan (\$20 million in 2000), which rehabilitates the most deteriorated sections of the Dushanbe-Kulyab road in the southern part of Tajikistan, the most civil-war affected areas; and the first phase of Dushanbe-Kyrgyz Border Road Rehabilitation Project loan (\$15 million in 2003), which improves Tajikistan's transportation link toward north and east through Kyrgyz Republic, further to Kazakhstan and Russia as well as to the Peoples Republic of China. These projects also improve rural roads in the project areas. The second phase of the Dushanbe-Kyrgyz Border Road Rehabilitation Project loan is being prepared for the ADB Board approval in 2005. Continued supports in strengthening the government's institutional capacity for efficient management of national road network are provided under technical assistance grants associated with these loans.

- $\quad$ Power Sector: the Power Rehabilitation Project loan (\$34 million in 2000), which aims to improve people's quality of life and support poverty reduction by increasing the availability of electricity, and assist in post-conflict recovery of Tajikistan's economy (the project rehabilitates and reinforces power transmission and distribution facilities in the war-damaged areas in Khatlon and Dushanbe regions, and rehabilitates the Nurek Power Plant and Central Hydropower Plant); and the Regional Power Transmission Modernization Project loan (\$20 million in 2002), which is geared towards improving the reliability and the operation of the Central Asian power 
transmission system, enhancing the intercountry power trading between Tajikistan and Uzbekistan, and laying the foundation for a future wholesale regional power market. Various technical assistance projects were provided to accelerate marketoriented reforms in the power sector in line with IMF and WB programs and for supporting the government in formulating a power sector development strategy. The second Power Rehabilitation Project loan is being prepared for ADB Board approval in 2006.

3. In addition to the above, the ADB Board approved to date the following loans to Tajikistan in each sector:

- Social Sector: the Social Sector Rehabilitation Project loan (\$20 million in 1999) to address the serious deterioration in living standards and strengthen the delivery of essential social services; the Health Sector Reform Project loan (\$7.5 million in 2003), which aims to improve health, especially of the poor, women, and children by providing pro-poor health service package, and by reforming the health service delivery and financing mechanism; and the Education Sector Reform Project loan (\$7.5 million in 2003), which focuses on supporting the government's reform priorities in primary (grades 1-4) and general secondary education (grades 5-11) by improving the education system and its management. These two social sector reform loans are being supported by respective grants financed by Japan Fund for Poverty Reduction (JFPR): (a) the project for Community Participation and Public Information Campaign for Health Improvement (\$1 million in 2004); and (b) the School Improvement Project (\$2 million in 2004), which aims to increase access to improved education for children, particularly girls, of poor families and vulnerable groups.

- Agriculture Sector: based on the agriculture sector assessment prepared during 1999-2000, the Agriculture Rehabilitation Project loan (\$35 million in 2002) is being implemented to improve living conditions of the farming communities in the project area and to institute measures to sustain benefits of improvements for irrigation and drainage systems and water supply as well as by providing farm production support services. In order to support the agriculture sector reforms, the TA for Farm Debt Resolution and Policy Reforms, which is associated with the loan, has been implemented in consultation with the IMF, involving a wide range of stakeholders. Based on the findings of the TA, ADB supported the government in close cooperation with other donors and NGOs for formulating a National Farm Debt Resolution Strategy. A wide range of donor assistance is now needed as the Strategy has been announced by the government. Grant assistance for Rural Poverty Reduction Project (\$2.9 million in 2001) financed by JFPR has supported the loan preparation and implementation by pilot testing innovative poverty-oriented on- and off-farm supports. In 2004, Irrigation Rehabilitation Project loan was approved for $\$ 22.7$ million. 
- $\quad$ Finance: Microfinance Systems Development Program loan (\$4 million in 2003) to support policy, legal, and regulatory reforms; and Microfinance Systems Development Project loan ( $\$ 4$ million in 2003) to help transform nongovernmental organization microfinance programs into licensed and regulated microfinance institutions.

- $\quad$ Trade Facilitation: the Regional Trade Facilitation and Customs Cooperation Program loan (\$10 million in 2002), which supports trade and customs reform development across the East and Central Asia. Regional Customs Modernization and Infrastructure Development (\$10.7 million in 2004) to promote international trade and enabling environment for private sector development.

- $\quad$ Emergency Assistance: in response to the government's urgent requests, three emergency loans, including the Emergency Flood Rehabilitation Project loan (\$5 million in 1999), the Emergency Restoration of Yavan Water Conveyance System loan (\$3.6 million in 2001), and the Emergency Baipaza Landslide Stabilization Project loan (\$5.3 million in 2002) were approved.

4. As of December 2004, in addition to the above 17 loans, totaling $\$ 244.3$ million, and 3 JFPR grant projects, totaling $\$ 5.9$ million, ADB provided 43 technical assistance grants, totaling \$21.2 million to support policy reforms, capacity building, and project implementation.

5. In end 2000, ADB started supporting the government in developing PRSP through participatory approach under a TA grant in close cooperation with the IMF, WB, and UNDP. Following the finalization of the PRSP in June 2002, ADB concluded the Poverty Partnership Agreement (PPA) with the government in December 2002, and proceeded to prepare a new five-year Country Strategy and Program (CSP) for 2004-08 for Tajikistan, which was endorsed by the ADB Board in October 2003. Its main objectives are (a) to strengthen rural development through institution building that will support policy implementation and the private sector; (b) to rehabilitate power and rural infrastructure; and (c) to strengthen regional cooperation through improved customs services and transport links, both within the country and neighboring ones. In view of the current challenging circumstances for development, including the limited borrowing capacity of Tajikistan, the CSP was not able to support all areas identified in the PRSP and the PPA.

6. ADB prepares and updates its three-year rolling programs for Tajikistan every year in consultation with the government based on the ADF resources availability, carefully examining the country's social and economic development status and in coordination with other donors, including IMF. The Country Strategy Update for 2005-06 was approved by the Board in September 2004. ADB pays full attention to the progress of Tajikistan's MDG achievement. In the past, in view of the ceiling on borrowing for the PIP and an expected inflow of grant funds committed for social sectors during previous consultative group (CG) meetings, ADB remained involved in the social sector mainly through non-lending operations, enabling it to take part in policy dialogue and follow sector developments. 
However, in line with the enhanced emphasis of the Government on social sectors, ADB proposes to resume lending in the sector in its program for 2006-08. It also plans technical assistance support for governance reforms. The total country indicative planning figure of ADF lending level for Tajikistan is \$25 million for 2006 and \$37 million for 2007-08. These figures include a 40 percent grant element. Moreover, Tajikistan will be a potential candidate for regional projects amounting to $\$ 55$ million over 2006-08. In addition, nonlending operations are proposed for $\$ 3.6$ million over 2006-07. This excludes cofinancing. The actual lending level will be determined by (a) availability of overall ADF resources; (b) country performance assessment vis-à-vis ADB's policy on performance based allocation of ADF resources; and (c) processing status of the projects in the pipeline. 


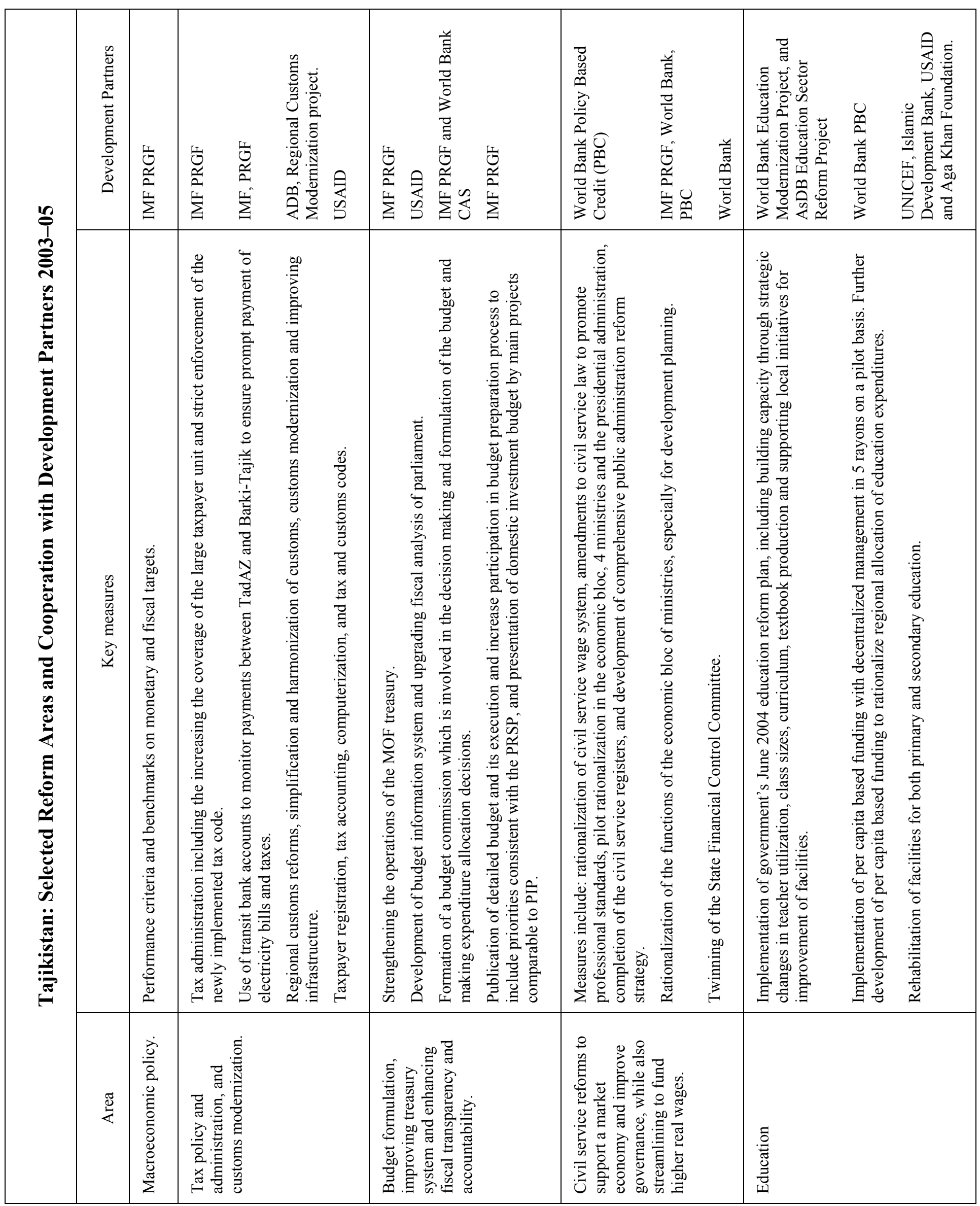




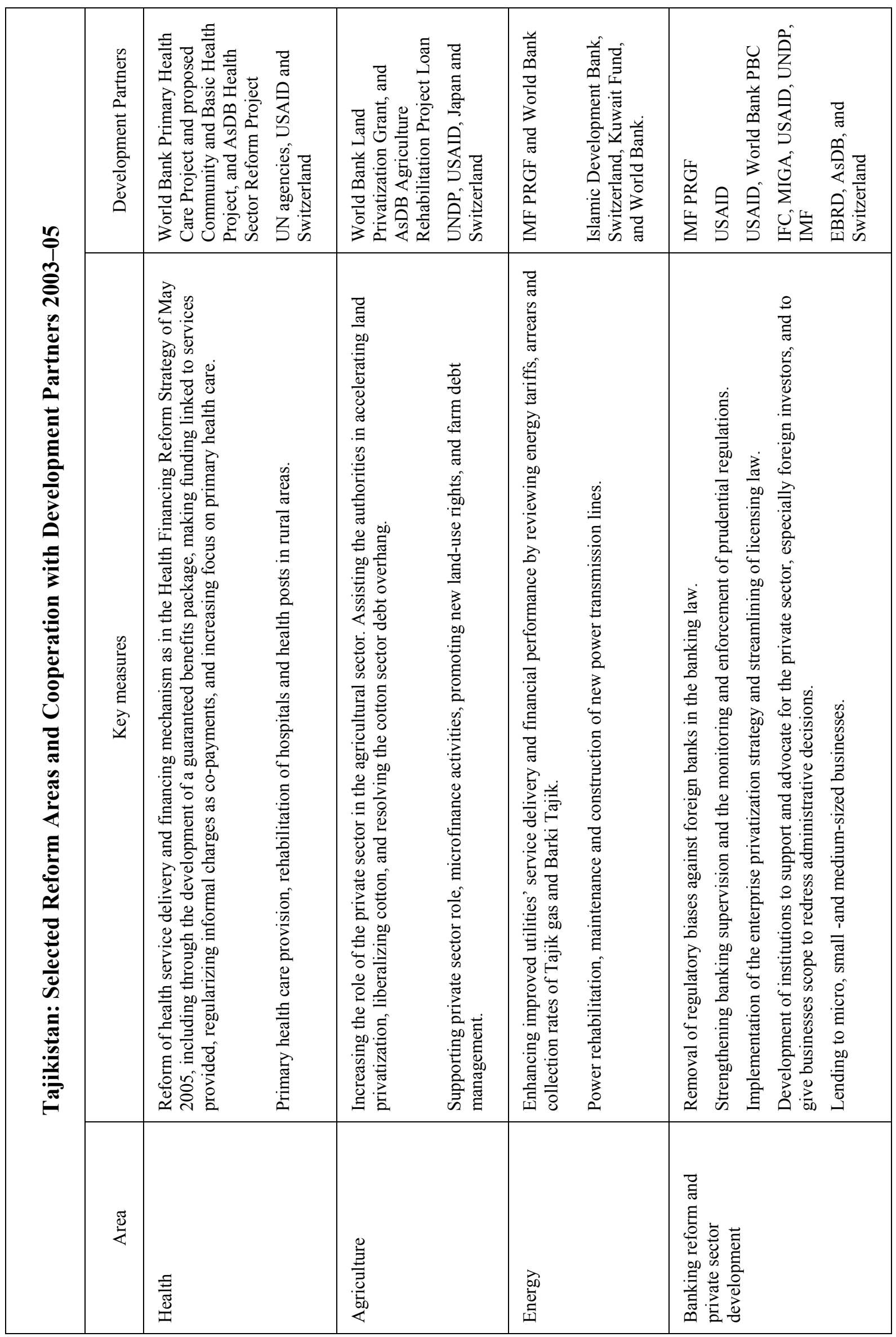




\section{TAJIKISTAN: STATISTICAL ISSUES}

1. The country page for Tajikistan was introduced in the International Financial Statistics (IFS) in February 2003. A data ROSC mission visited Tajikistan between April 5-19, 2004. The mission assessed that compilation of consumer prices, government finance statistics, and monetary statistics broadly follows sound methodologies. However, an intensified effort is needed to strengthen the scope, classification/sectorization, and basis of recording of the national accounts, and to reconsider the concepts and the basis of recording the input data underlying compilation of the producer price index (PPI). Furthermore, there is need for consistency in applying the residency concept in the balance of payments and the national accounts statistics. The scope of the foreign trade data needs to be improved to cover the shuttle trade.

2. The data ROSC mission also noted that source data are well developed in all areas of statistics, and suitable processes for assessment and validation of source data are in place. Significant deficiencies in statistical techniques were observed for national accounts, most notably in procedures used to estimate the informal economy and in the exclusion of export prices in the PPI. The National Bank of Tajikistan needs to give more attention to revision studies in monetary statistics. Efforts to further improve the quality of economic statistics are limited by tight budgetary constraints.

3. A General Data Dissemination System (GDDS) metadata development mission visited Dushanbe between October 7-15, 2004. Tajikistan has participated in the GDDS since November 2004 when finalized metadata were posted on the Fund's Dissemination Standards Bulletin Board.

\section{National Accounts Statistics}

4. Although Goskomstat has made serious efforts to improve the national accounts statistics, the compilation of GDP estimates needs to be strengthened. The national accounts concepts and definitions are based on the conceptual framework developed by the CIS Statistics Committee, which agree broadly with the 1993 System of National Accounts, although there are some deviations from international standards in the scope of production and assets boundaries. Annual GDP estimates are derived from the production side by supplementing the net material product data reported by enterprises with estimates for services. The derived nominal GDP estimates are difficult to reconcile with the sectoral growth rates, forecasted CPI and terms of trade developments. The accuracy of the GDP current price estimates is undermined by inadequate coverage of new private sector activities and by improper valuation. Goskomstat has introduced new data collection measures to improve the coverage of activities, especially by unincorporated enterprises. Valuation of reported inventories and consumption of fixed capital do not agree with international standards. The techniques used for deriving volume measures of GDP by activity are not sound. Currently, no official volume measures of GDP by expenditure have been compiled.

5. Although Goskomstat is aware of the benefits of producing independent quarterly 
GDP estimates, these estimates are still compiled on experimental basis as cumulative figures through extrapolation using indices of sectoral output at a highly aggregated level. The decumulated quarterly GDP figures show a marked seasonal pattern, with output increasing strongly at the time of the fall harvest. The current practice of collecting cumulative totals results in inaccurate quarterly estimates, since the quarterly data are obtained by subtracting successive cumulative totals, and consequently include a revision component. Other features of the previous system also persist. In particular, there is a strong demand for detailed data on individual enterprises, which ties up resources that could otherwise be put to better use. It is hoped that, with the dissemination of the revised annual estimates, Goskomstat will introduce proper techniques to benchmark the quarterly series to the annual estimates. While reorienting its data collection effort within sampling frameworks, Goskomstat needs to undertake a strategic reappraisal of its production activities and significantly reduce the volume of microdata presently collected, while educating users to focus on statistical aggregates.

\section{Price Statistics}

6. Since January 1994, Goskomstat has compiled a consumer price index (CPI) on a monthly basis. The index was compiled with technical assistance from STA. A producer price index (PPI) is also compiled on a monthly basis. At present, the PPI does not follow international standards (PPI Manual) and suffers from a number of shortcomings in the scope of the index and the basis for recording. The statistical techniques for compiling both CPI and PPI need to be improved.

\section{Government Finance Statistics}

7. Since January 2000, the classification of fiscal accounts follows the IMF's Manual on Government Finance Statistics 1986 (GFSM 1986). The new accounts were developed with FAD technical assistance. There are no plans at present to migrate the basis of compilation to the new GFS standards based on the Government Finance Statistics Manual 2001 (GFSM 2001). The 2002 budget follows GFS, and its execution is also reported with the GFS classification system. However, the weakness inherent in the accounting system and the poor quality of data limit the benefits from the GFS system. Statistics on state budget operations are available about two to three weeks after the end of the reference period.

8. Statistics are produced for the general government sector. GFS cover all the economic flows, and the stock of debt, of general government to the standard specified in GFSM 1986. Sectorization of government is consistent with general government in the 1993 SNA. Revenue, expenditure, lending minus repayments, and financing transactions, are classified using the methodology set out in GFSM 1986. All flow data are recorded on a cash basis, valued on the basis of the amount of actual payments and receipts in cash, as recommended in GFSM 1986. Data covering the consolidated central government as well as the consolidated local government for 1998-2001 have been reported by Tajikistan for publication in the 2002 GFS Yearbook, an effort that was disrupted in 2003. Monthly data on the operations of central government are not reported for inclusion in IFS. In addition, further 
work could usefully target, in particular, improving the financing information (classification and valuation of transactions), consistent with the government debt. Steps should also be taken to ensure availability of information on the public sector as well as on quasi-fiscal operations.

\section{Money and Banking Statistics}

9. The procedures used by NBT for collecting and compiling monetary statistics are in line with the framework of Monetary and Financial Statistics Manual as recommended by STA missions. However, due to ongoing revisions to the charts of account for the NBT and commercial banks, the NBT staff need to routinely review and update the complementary computer program for compilation of monetary statistics by appropriately incorporating and classifying all new balance-sheet accounts in the monetary survey. Currently, some nonresident accounts are included in other assets and other liabilities rather than under foreign assets and foreign liabilities of the monetary survey.

10. The authorities and the USAID team assisting the NBT in improving banking supervision have indicated their desire for Fund assistance in revising the chart of accounts for commercial banks and monetary statistics report forms. The USAID team has identified a number of weaknesses in the existing chart of accounts for the commercial banks and proposed revisions to ensure suitability for monetary statistics and banking supervision purposes.

\section{Balance of Payments Statistics}

11. The balance of payments statistics have been compiled by the Balance of Payments Statistics Unit of the NBT since January 1997. The NBT is responsible for establishing the statistical methodology, reporting forms, data collection, verification, processing, compilation and dissemination of balance of payments data. Working arrangements among government agencies that provide statistical data for balance of payments compilation are consistent with their assignments of responsibility.

12. The authorities have made significant improvements in compiling the balance of payments statistics with assistance provided by STA. The ROSC mission found that most recommendations of previous missions had been implemented and that the NBT has adopted alternative statistical treatments for workers' remittances and clarified valuation for humanitarian aid and petroleum products. However several important pending issues need to be corrected: collection is based on two incompatible definitions for residency that hamper proper coverage and are a source for errors and omissions. In several instances, complete coverage is hampered by missing information. The NBT should liaise with other producing agencies, chiefly the Goskomstat, to review and supplement missing information, for instance to cover completely shuttle trade, transactions of foreign-owned direct investment enterprises, private debt and to adequately record forward contracts for cotton producing companies. Also, inadequate coordination between the NBT and the Goskomstat explain enduring discrepancies in trade series produced by both agencies. 
13. Regarding the institutional environment for the compilation of balance of payments statistics, the ROSC mission noted that legal provisions are still missing to adequately protect the confidentiality of individual information. In addition, no documentation is made available to balance of payments statistics users, and no advance notice is given to users for major changes in the methodology, data sources, and statistical techniques. However, since May 2003, the main coordination body became a legal entity (Interagency Commission for Coordinating Balance of Payments Preparation and Compilation) and is entitled to adopt executive decisions to carry out on all relevant tasks in balance of payments statistics, but has no representation for private users of statistics. 


\section{TABLE OF COMMON INDICATORS REQUIRED FOR SURVEILLANCE}

\section{AS OF JUNE 27, 2005}

\begin{tabular}{|c|c|c|c|c|c|c|c|}
\hline & \multirow{2}{*}{$\begin{array}{c}\text { Date of } \\
\text { latest } \\
\text { observation }\end{array}$} & \multirow{2}{*}{$\begin{array}{c}\text { Date } \\
\text { received }\end{array}$} & \multirow{2}{*}{$\begin{array}{c}\text { Frequency } \\
\text { of } \\
\text { Data }^{6}\end{array}$} & \multirow{2}{*}{$\begin{array}{l}\text { Frequency } \\
\quad \text { of } \\
\text { Reporting }^{6}\end{array}$} & \multirow{2}{*}{$\begin{array}{l}\text { Frequency } \\
\text { of } \\
\text { publication }^{6}\end{array}$} & \multicolumn{2}{|c|}{ Memo Items: } \\
\hline & & & & & & $\begin{array}{l}\text { Data Quality - } \\
\text { Methodological } \\
\text { soundness }\end{array}$ & $\begin{array}{l}\text { Data Quality - } \\
\text { Accuracy and } \\
\text { reliability }\end{array}$ \\
\hline Exchange Rates & $06 / 23 / 05$ & $06 / 27 / 05$ & $\mathrm{D}$ & W & $\mathrm{W}$ & & \\
\hline $\begin{array}{l}\text { International Reserve Assets and } \\
\text { Reserve Liabilities of the Monetary } \\
\text { Authorities }{ }^{1}\end{array}$ & $06 / 16 / 05$ & $06 / 21 / 05$ & $\mathrm{~W}$ & W & $\mathrm{W}$ & & \\
\hline Reserve/Base Money & $06 / 16 / 05$ & $06 / 21 / 05$ & $\mathrm{~W}$ & W & $\mathrm{W}$ & \multirow[t]{3}{*}{$\mathrm{O}, \mathrm{O}, \mathrm{LO} \mathrm{O}$} & \multirow[t]{3}{*}{$\mathrm{LO}, \mathrm{O}, \mathrm{O}, \mathrm{O}, \mathrm{NO}$} \\
\hline Broad Money & $04 / 30 / 05$ & $06 / 13 / 05$ & M & M & M & & \\
\hline Central Bank Balance Sheet & $06 / 16 / 05$ & $06 / 21 / 05$ & W & W & $\mathrm{W}$ & & \\
\hline Consumer Price Index & $05 / 31 / 05$ & $06 / 06 / 05$ & M & M & M & LO, LO, LNO, O & $\begin{array}{l}\mathrm{LO}, \mathrm{LO}, \mathrm{LO}, \mathrm{O} \\
\mathrm{O}\end{array}$ \\
\hline $\begin{array}{l}\text { Revenue, Expenditure, Balance and } \\
\text { Composition of Financing }{ }^{3}-\text { General } \\
\text { Government }\end{array}$ & $04 / 30 / 05$ & $05 / 19 / 05$ & M & M & M & \multirow[t]{2}{*}{ LO, LO, O, O } & \multirow[t]{2}{*}{$\mathrm{O}, \mathrm{O}, \mathrm{O}, \mathrm{LO}, \mathrm{LO}$} \\
\hline $\begin{array}{l}\text { Revenue, Expenditure, Balance and } \\
\text { Composition of Financing }{ }^{3}-\text { Central } \\
\text { Government }\end{array}$ & $04 / 30 / 05$ & $05 / 19 / 05$ & M & M & M & & \\
\hline $\begin{array}{l}\text { Stocks of Central Government and } \\
\text { Central Government-Guaranteed Debt }\end{array}$ & Q1/05 & $04 / 19 / 05$ & $\mathrm{Q}$ & Q & $\mathrm{V}$ & & \\
\hline Gross External Debt ${ }^{5}$ & Q4/04 & $03 / 31 / 05$ & Q & Q & $\mathrm{V}$ & & \\
\hline
\end{tabular}

${ }^{1}$ Includes reserve assets pledged or otherwise encumbered as well as net derivative positions.

${ }^{2}$ Both market-based and officially determined, including discount rates, money market rates, rates on treasury bills, notes and bonds.

${ }^{3}$ Foreign, domestic bank, and domestic nonbank financing.

${ }^{4}$ The general government comprises central government (budgetary, extra budgetary, and social protection funds) and state and local governments.

${ }^{5}$ Including currency and maturity composition.

${ }^{6}$ Daily (D), Weekly (W), Monthly (M), Quarterly (Q), Annually (A); NA: Not Available.

${ }^{7}$ Reflects the assessment provided in the data ROSC or the Substantive Update for the dataset corresponding to the variable in each row. The assessment indicates whether international standards concerning concepts and definitions, scope, classification/sectorization, and basis for recording are fully observed (O), largely observed (LO), largely not observed (LNO), or not observed (NO).

${ }^{8}$ Same as footnote 8 , except referring to international standards concerning source data, statistical techniques, assessment and validation of source data, assessment and validation of intermediate data and statistical outputs, and revision studies. 


\section{President \\ of the Republic of Tajikistan}

Dushanbe

Republic of Tajikistan

July 2, 2005

Dear Mr. de Rato:

I would like to take this opportunity to thank the International Monetary Fund for its continued support of our economic reforms and development programs.

In April 2005 the Government of Tajikistan held discussions with Fund staff for the fifth review under the Poverty Reduction and Growth Facility (PRGF). Based on these discussions, we have prepared a supplement to the Memorandum of Economic and Financial Policies (MEFP) of February 7, 2005. This supplement reflects the impact of recent economic developments on the macroeconomic framework, and proposes revisions to the performance criteria and additional measures for the period April 1-December 31, 2005.

I am pleased to report that we have made further progress in strengthening macroeconomic stability. The Tajik economy has continued to expand at a robust pace, inflation has remained moderate and the somoni exchange rate has been relatively stable. Budget revenue collections have been marginally higher than planned and expenditure has been kept well within the budget limits. We have observed all but one quantitative performance criteria for end-March 2005. The nonobservance of the floor on net international reserves (NIR) was temporary and due to a technical delay in the receipt of a program grant. On this basis, a waiver is being requested. We have completed the March 2005 structural benchmark on the Tajik Aluminum Plant (TadAZ), and have made considerable progress in implementing the benchmark concerning the rationalization of the functions of economic ministries. Also, the data for May 2005 indicate that we are likely to observe all quantitative targets for end June 2005, and we have made substantial progress in implementing the June structural benchmarks.

Based on the performance during the period through May 2005 and the policies set out in the attached supplementary Memorandum, we request the completion of the fifth review under the PRGF arrangement and request that the sixth review of the program take place on or after December 1, 2005. In addition, because of some delays in program implementation, we request that the PRGF arrangement be extended by two months to February 10, 2006.

The Government believes that the policies set forth in the attached Memorandum are adequate to achieve its objectives, but it will take any further measures that may become appropriate for this purpose. The Government will consult with the Fund on the adoption of 
these measures, and in advance of revisions of the policies contained in the MEFP, in accordance with the Fund's policies on such consultations. In addition, we will provide the staff with the information required for monitoring economic developments and progress in program implementation.

In line with our commitment to transparency, we hereby request that the staff report, this letter of intent, and the attached Memorandum of Economic and Financial Policies (including all annexes) be published on the IMF website.

Please accept, Your Excellency, the assurances of my highest consideration.

\author{
To His Excellency \\ Mr. Rodrigo de Rato \\ Managing Director \\ International Monetary Fund
}




\section{REPUBLIC OF TAJIKISTAN}

\section{Supplementary Memorandum of Economic and Financial Policies for the Period April 1, 2005 to December 31, 2005 Under the Poverty Reduction and Growth Facility}

July 2, 2005

1. This Supplementary Memorandum of Economic and Financial Policies (SMEFP) reviews recent performance under the program of economic and financial reforms supported by the International Monetary Fund under the Poverty Reduction and Growth Facility (PRGF). It also details additional economic policy measures under the third annual program contained in our Letter of Intent and MEFP of February 17, 2005 (February MEFP).

\section{Recent Developments and Performance Under the Program}

2. The macroeconomic environment remains positive. In the first quarter of 2005 , real GDP rose by 7.8 percent relative to the first quarter of 2004 , while consumer price inflation - at 6.5 percent - was slightly above expectations. Remittances from migrant workers, entrepreneurs, and small-scale exporters continued to boost household incomes and consumption and finance rapidly growing imports. After increasing to 7.3 percent of GDP in 2004, the trade deficit widened further in the first quarter of 2005 due to weak cotton and aluminum export prices and increased prices for imported fuels. The import cover of the NBT's gross international reserves fell slightly to 1.8 months of prospective imports at end March 2005, and the exchange rate remained broadly stable.

3. Sharply lower than projected government expenditure yielded a larger than projected budget surplus in the first quarter of 2005. Expenditure was low during the first quarter owing to delays in budget execution related to the introduction of the new budget classification, and to the need to recalculate wages and pensions following significant increases. While tax revenue was in line with the program, its composition differed from the projection. Receipts from the cotton sales tax were weak, owing to low cotton prices and delays in export shipments, but higher VAT receipts, boosted by strong consumer demand, more than offset this weakness. The implementation of the new tax and customs codes is proceeding and tax officials are adjusting to the new procedures.

4. Implementation of monetary policy focused on maintaining low inflation. Reserve money was substantially below the end-March 2005 program target. Commercial bank lending, with the exception of credit to agriculture, remained relatively subdued as banks focused on low risk lending and loan recovery to strengthen their capital base to meet the higher minimum capital requirements. The NBT reduced the required reserve ratio from 18 percent to 15 percent in May 2005. 
5. All but one of the quantitative performance criteria under the Fund-supported program were observed (Annex I). The exception was net international reserves, which were temporarily below the program's target because of a delay (from March to early May) in the receipt of a program grant.

6. The indicative target for the avoidance of domestic arrears to utility companies was not observed in the March quarter, owing to the accumulation of arrears by TadAZ to Barki Tajik, repeating the problems of the December quarter 2004, but on a smaller scale. To address TadAZ's arrears, a transit account system was introduced for the company's electricity payments (structural benchmark for March 2005) at end April. Under this mechanism, TadAZ is paying the current cost of electricity and will pay the arrears according to the agreement under SAC 2. If TadAZ's payments are delayed, its bank will debit the needed funds from TadAZ's other bank accounts. Transactions on these accounts will be reported promptly to the NBT.

7. The reform of public administration is continuing. Specific plans for the four pilot ministries and the presidential administration are being developed. However, progress on the structural benchmark (for March 2005) for the streamlining of economic ministries, including the elimination of detailed production planning and the rationalization of aid coordination and planning, has been slower than anticipated. A presidential decree outlining the new organizational structure and distribution of the economic planning functions will be issued by early July, for implementation by end- September. Pilot programs for reforms in the financing arrangements for education and health are underway in several rayons. These have already contributed to the rationalization of some school facilities and the development of a guaranteed benefit package, which emphasizes publicly-financed maternal and child health care.

\section{Updated Policies for the Third Annual Program}

8. Recent developments suggest that while the key economic objectives in the February MEFP remain appropriate, some adjustments will be needed because of the weaker external environment. Real GDP growth is projected to be at least 8 percent in 2005 and inflation (12-month basis) is expected to reach 7 percent by the end of the year, slightly higher than originally envisaged. The main risks to this projection come from the recent downward trend in commodity prices, especially for cotton and aluminum, which could adversely affect both the growth outlook and the external position. Also, further increases in petroleum and gas prices, and higher inflation in some of Tajikistan's major trading partners, could put upward pressure on inflation.

\section{A. Fiscal Policy}

9. Developments so far in 2005 indicate that the budget framework for 2005 still holds. However, as a result of marginally stronger revenues in the first quarter and higher grants, the overall deficit (excluding the foreign financed public investment program, PIP) is 
projected to decline to 0.1 percent of GDP, compared with 0.5 percent in the original program. At the same time, domestic bank financing of the deficit will increase marginally (by 0.2 percent of GDP, to 0.6 percent of GDP) to compensate for the projected decline in net foreign financing following delays in the disbursement of the World Bank's Policy Based Credit.

10. In order to continue with its revenue efforts, the government will strengthen implementation of the new tax and customs codes and the enforcement of payments from large taxpayers. To support the revenue mobilization effort, ministry of state revenues and duties (MSRD) will move expeditiously to increase the coverage of the large taxpayer inspectorate (LTI) (structural benchmark, June 2005). Although it was originally envisaged that the coverage of large taxpayers by the LTI would rise from 55 percent of taxes in December 2004 to 60 percent in June 2005, weaker performance by some existing large taxpayers in the cotton sector reduced the tax base. Thus, the MSRD will redouble efforts to add new large enterprises (including telecoms) to raise the coverage by 5 percentage points of tax collections, the originally envisaged increment, by end-June. In addition, the MSRD will use future external audits of TadAZ, which will be provided to MSRD, to review TadAZ's tax returns.

11. The government recognizes that the new investments in the energy and aluminum sectors contribute significantly not only to production and employment, but also to the budget. In this respect, TadAZ's operations will continue to be subject to the current legal framework, including the tax code, which for 2005 implies SM 13 million per month in tax payments. Any changes in tax arrangements will be fully evaluated for their revenue impact in subsequent years and in accordance with the legal framework.

12. The second tranche of the wage bill increase (SM 16 million) will be allocated to the sectors implementing the planned reforms foreshadowed in the February MEFP. Since general education reform has started in the five pilot rayons, the education sector will be allocated SM 4 million. The financing reform for the health sector was approved by the government in May, and new structures for the four pilot ministries and the presidential administration will be adopted by end-June. The remaining SM 12 million will be released after September 2005, conditional on the completion of the civil service registries, adoption of the rationalized wage structure, and implementation of new administrative and health reforms developed in consultation with the World Bank. Some of these funds may also be used for retrenchment.

13. After the implementation of the new budget classification system at the start of 2005 , progress in improving fiscal transparency will continue with four important steps:

(a) publication of the detailed 2004 budget execution report and the 2005 budget documents in both hard copy and on the internet, including expenditures classified by function, economic type, and key budget organization, and with details of domestically funded capital expenditures; (b) enhancement of the 2006 budget preparation process with the formulation of priorities that reflect those being developed for the new Poverty Reduction Strategy Paper (PRSP) and Socio Economic Development Plan (SEDP); (c) presentation of the domestic 
investment budget for 2006 by main project comparable to the PIP; and (d) progressive introduction of per capita funding in education at the rayon level and on a nationwide basis (supplemented by factors that account for remoteness and age of facilities), starting with the 2006 budget.

14. To strengthen the treasury system, we have made progress in setting up the cash management unit to enhance the use of the single treasury account, which will become operational by September 2005 (structural benchmark). The completion of other elements of the benchmark, such as strengthening the links between the central treasury and its local branches, is being reviewed by an FAD technical assistance mission in July 2005.

15. To broaden the range of financial instruments, the MOF will start to issue SM 3 million of 28-day term marketable treasury bills in June 2005. Each weekly auction will be for about one quarter of this amount, and the management of these securities will be handled by the NBT, which will act as the MOF's agent. In addition, the NBT and the MOF will reach an agreement on the terms for the settlement of interest on government bonds and deposits by end-August 2005. The somoni bonds and deposits will earn interest calculated by explicit margins over inflation.

\section{B. Monetary and Exchange Rate Policies}

16. Monetary policy and quantitative targets for the remainder of 2005 will continue to be guided by the February MEFP, with reserve money targeted to grow by under 10 percent in order to keep inflation in check. The NBT will use the newly issued treasury bills as a first step in developing money market instruments. The NBT may consider a further reduction in the required reserve ratio in early 2006, after evaluating the impact of the recent reduction on lending.

17. The NBT has reduced its claims on the private sector (including banks) by a substantial part of the SM 10 million (structural benchmark for June 2005) and further collections are expected in the near future. The NBT will continue to recover such debt in the second half of 2005. This will be accomplished by enforcing debt repayments and the sale of collateral held in lieu of some of the nonperforming loans. The NBT will not relend the recovered funds.

18. The NBT will maintain the managed float exchange regime, limiting intervention in the foreign exchange market to reducing excess exchange rate volatility and building up international reserves to maintain an appropriate coverage of imports. The NBT will move to daily adjustment of the official exchange rate by end-August 2005. The adjustments will reflect the exchange rates in transactions from the previous day in the interbank market and between the banks and their clients. 


\section{External Debt Management Policies}

19. The NBT and the government will continue to prohibit all external nonconcessional borrowing contracted or guaranteed by the government, and will not draw on any outstanding nonconcessional credit facilities. While a substantial part of the public sector external debt inventory has been completed, the MOF will extend the coverage of the database to external debts of public enterprises without government guarantees. The MOF will also build on the recent achievements in debt data management and reports of past trends to develop the technical and analytical capacity to perform debt sustainability analysis. Work for developing a database of external liabilities of the private sector related to the cotton sector (structural benchmark for June 2005) is underway with the inclusion of the largest creditors, and the NBT will make further progress to complete the coverage of all creditors by September 2005.

\section{Other Structural Policies}

20. The NBT will publish the full external audit report for the 2003-04 financial year by the end of June 2005. This will be both in hard copy and on the NBT's external website. The external audit for the financial year ending on April 30, 2005 will be completed by the end of August 2005. Subsequently, the report will be sent to Parliament and placed on the NBT's external website. Anti-money laundering legislation is being developed and is expected to be presented to parliament for consideration by end-2005.

21. The NBT will continue to monitor and enforce compliance with all prudential regulations. While recognizing that the delays in cotton shipments in early 2005 were the main reason behind low loan repayments and the resulting sharp seasonal increase in outstanding credit, the NBT will enhance monitoring of commercial bank lending practices and their impact on nonperforming loans. Stronger prudential compliance may require the withdrawal of banking licenses from the weakest banks, particularly if they fail to meet the \$5 million minimum capital requirement applicable at the start of 2006. The government will also provide the state-owned Amonat Bank with the needed additional capital or find other sources of capital by the start of 2006. The amendments to the Banking Law to remove impediments to the entry of foreign banks have been reviewed by the government and will be submitted to Parliament by early July 2005. The NBT will support the creation of a credit bureau by encouraging banks to exchange data on borrowers and assisting in setting up a centralized database.

22. Recognizing the importance of diversifying the economic base, the government will strengthen the framework to promote the development of the private sector. One of the near-term tasks will be to streamline business regulation, including by significantly reducing the coverage of the Licensing Law, and to work with line ministries to enhance competition in the provision of international quality business services, especially air travel and telecommunications.

23. The government has adopted a strategy to resolve the problem of cotton sector debt that precludes the issuance of government guarantees. The strategy foresees the 
establishment of an independent commission to address the debt problem on a case-by-case basis. The modalities of the independent commission are still being discussed with donors,

but should be finalized in the near future. Other recent measures to improve agriculture include the elimination of local government interference with cotton production and land use decisions by farms, and the acceleration of farm privatization.

24. The government is committed to promoting the development of accurate macroeconomic data and will start to pursue subscription to the Special Data Dissemination Standard (SDDS) as part of its efforts to enhance the accessibility and timeliness of statistics. Assistance from the IMF's Statistics Department in developing the remaining required datasets and updating the necessary metadata will be sought, and a timetable for subscription to SDDS will be developed.

25. As outlined in the second annual Progress Report on the implementation of the PRSP, the government will coordinate more systematically the public investment and policy framework in support of growth. To achieve this, it will develop and adopt an interim National Development Strategy for the period 2006-08 by end-2005. This will integrate the SEDP, the PRSP, and the plan for progress towards the Millenium Development Goals. Drafts will be made public and input from civil society will be incorporated.

\section{E. Program Monitoring}

26. The program targets for end-September and end-December 2005 are detailed in Annex I and remain largely the same as in the February MEFP. Structural performance criteria and benchmarks through end-September 2005 are contained in Annex II. All of the structural measures will be implemented before the completion of the sixth review under the arrangement, subject to the understandings specified in this memorandum. Performance relative to these targets, criteria, and benchmarks will be measured as detailed in the Technical Memorandum of Understanding in Annex III.

27. To promote transparency, the letter of transmittal and the Memorandum of Economic and Financial Policies will be published on the Tajikistan government and IMF websites.

Annex I: $\quad$ Quantitative Performance Criteria

Annex II: $\quad$ Structural Performance Criteria and Benchmarks

Annex III: Technical Memorandum of Understanding 


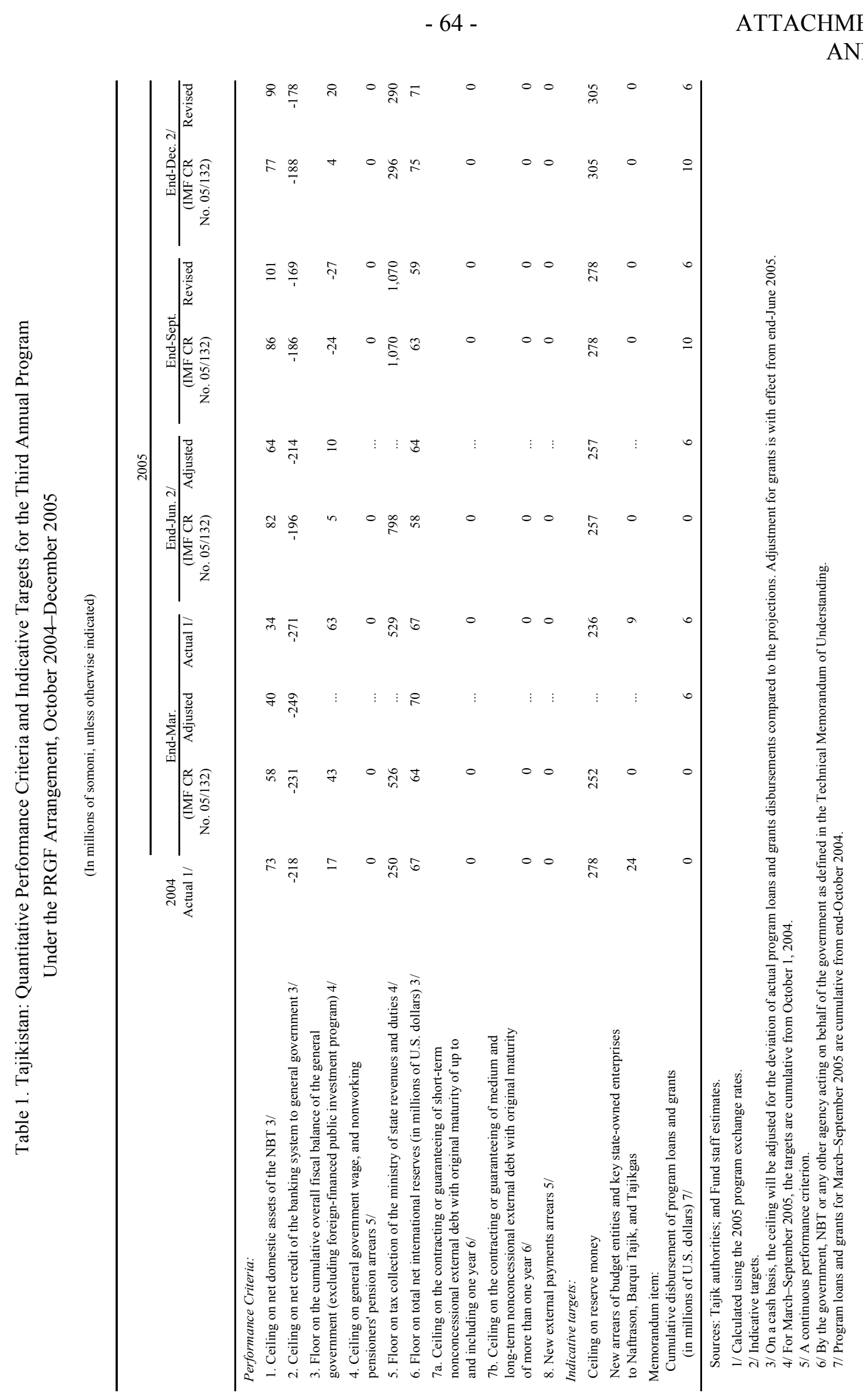




\section{Tajikistan: Structural Performance Criteria and Benchmarks for the Third Annual Program Under the PRGF Arrangement, 2005}

Measures

Status

(as of June 15, 2005)

\section{Continuous structural performance criteria (through May 2005)}

Prohibit the NBT from issuing directed credits.

Observed

Prohibit the NBT from making expenditures not related to its core business activities or paying dividends while it has negative net worth.

Observed

Implement quarterly adjustments of all utility tariffs, equivalent to the depreciation in the nominal exchange rate in the previous quarter.

\section{Structural benchmarks}

\section{For end-March 2005}

Implement the mechanism to ensure the immediate transfer to the treasury by Barki Tajik of the tax portion of TADAZ's payments to Barki Tajik.

As part of streamlining economic ministries, cease publication of detailed production targets disaggregated below the national level. Integrate various bodies preparing strategic plans and coordinating aid.

Observed in April

Partially observed, remainder in progress

\section{For end-June 2005}

Reduce NBT's claims on the private sector by SM 10 million from October 2004 to June 2005 through collateral sales or other loan recoveries.

Remove the regulatory limits on foreign capital in the banking system and the requirement for a Tajik citizen to head commercial banks in the banking law.

Expand the register of the Large Taxpayer Inspectorate (LTI) to cover at least 60 percent of total tax collections.

Develop and continuously update a database at the NBT for monitoring private sector external debt (starting with cotton sector debt).

\section{For end-September 2005}

Make fully operational a cash management unit in the ministry of finance and strengthen communication links between local branches of the central treasury with the headquarters to enhance fiscal management, cash control and forecasting. 


\section{REPUBLIC OF TAJIKISTAN}

\section{Technical Memorandum of Understanding}

1. Performance during third year of the PRGF-supported program will be assessed based on observance of quantitative performance criteria and structural benchmarks. This annex together with Annex I attached to the MEFP define the variables that constitute quantitative performance criteria and indicative targets under the program, and sets out the reporting requirements and frequency of data provision by the government and the NBT.

2. For the purpose of program monitoring, U.S. dollar-denominated components of the balance sheet will be valued at the program exchange rate, and other foreign currency denominated items will be valued at cross rates between the program exchange rate of the U.S. dollar and current official exchange rates of the U.S. dollar against those currencies. The program exchange rate for the U.S. dollar is SM 3.037 = \$1 (the end-December 2004 level). The SDR components will be valued at the program SDR exchange rate $(\mathrm{SDR} 1=\$ 1.54)$. Official gold holdings shall be valued at $\$ 438$ per troy ounce.

\section{Quantitative Targets}

\section{A. Fiscal Balance of the General Government}

Table 1. Ceiling on the Cumulative Overall Balance of the General Government

(In millions of somoni)

Cumulative balance from October 1, 2004 to:

December 31, 2004 (indicative target)

15

March 31, 2005 (performance criterion)

43

June 30, 2005 (indicative target)

5

September 30, 2005 (performance criterion)

Cumulative balance from October 1, 2005 to:

December 31, 2005 (indicative target)

20

\section{Definitions}

3. The general government budget is defined to include the republican budget, local (including municipal) budgets, and all extra-budgetary funds at all levels of general government, including the social protection fund (SPF) but excluding the externally financed public investment program. The overall cash balance of the general government is defined from the financing side as the sum of the following: 
(i) The change in stocks of the NBT on the general government which includes all deposits of the general government with the NBT, counterpart deposits (which reflect balance of payment and/or general budget support from IFIs and other donors), NBT loans and advances to the general government, NBT holdings of government securities, bank restructuring costs, and the privatization account (where proceeds from the privatization of state property are held);

(ii) The change in net claims (transactions) on the general government of the rest of the domestic banking system which are defined to include the net position of the general government with respect to other domestic commercial bank assets (loans, overdrafts, cash advances, holdings of treasury bills or other securities) and liabilities (deposits, etc.);

(iii) The change in net claims (transactions) on the general government of domestic nonbank institutions and households is defined to include net sales of treasury bills, bonds or other government securities to nonbank institutions and households (including nonresidents and nonresident financial institutions), plus any other increase in liabilities of the general government to domestic nonbank institutions or households. Included in this item are also compensation payments to Tajik Rail for its servicing of external debt to Uzbekistan;

(iv) Gross proceeds from the privatization of state property, which are kept in a separate account with the NBT, are defined as all receipts originating from the sale of state property; and

(v) Net foreign financing of the general government which is defined as the difference between gross disbursements of foreign financing excluding the externallyfinanced public investment program and amortization of government debt to foreign financial and nonfinancial institutions, plus principal arrears, debt rescheduling and the drawdown of Tajikistan's claim on the Central Bank of Russia.

\section{B. Total Tax Collections under the Budget}

Table 2. Floor on Total Tax Collections Under the Budget

\begin{tabular}{lc}
\hline & (In millions of somoni) \\
\hline Cumulative revenues from October 1, 2004 to: & \\
December 31, 2004 (indicative target) & 248 \\
March 31, 2005 (performance criterion) & 526 \\
June 30, 2005 (indicative target) & 798 \\
September 30, 2005 (performance criterion) & 1,070 \\
Cumulative revenues from October 1, 2005 to: & \\
December 31, 2005 (indicative target) & 290 \\
\hline
\end{tabular}




\section{Definitions}

4. Tax collections include all taxes collected under the budget. Regarding internal taxation, the definition excludes any proceeds from loans, or other banking system credits, the issuance of securities, or from the sale of state assets. Custom revenues are defined to include import duties, export duties and taxes, customs duties, exchange taxes, and other taxes (including VAT) on international trade and transactions.

\section{Limits on the Stock of Net Domestic Assets of the NBT}

Table 3. Ceiling on the Stock of Net Domestic Assets of the NBT

\begin{tabular}{lc}
\hline & (In millions of somoni) \\
\hline December 31, 2004 (indicative target) & 73 \\
March 31, 2005 (performance criterion) & 58 \\
June 30, 2005 (indicative target) & 64 \\
September 30, 2005 (performance criterion) & 101 \\
December 31, 2005 (indicative target) & 90 \\
\hline
\end{tabular}

\section{Definitions}

5. Net domestic assets (NDA) of the NBT are defined as: reserve money minus net foreign assets of the NBT. Reserve money is composed of currency in circulation, required reserves, other bank reserves, and deposits of nongovernment nonbanks with the NBT. The value of the net foreign assets of the NBT is calculated as the difference between NBT's claims on nonresidents and its liabilities to nonresidents. The NBT's net domestic assets comprise the following assets and liabilities: net credit to the general government, claims on banks, credit to the economy, and other items net (OIN). OIN includes the foreign exchange revaluation and capital accounts of the NBT.

\section{Adjustors}

6. The ceiling on net domestic assets of the NBT will be adjusted downward/upward by 100 percent for excesses/shortfalls of the disbursement of foreign program loans and grants. Program loans and grants are defined as loans or grants received in foreign exchange that are not tied to the purchase of specific goods and services and are intended for budget support. 


\section{Limits on Net Credit of the Banking System to General Government}

Table 4. Ceiling on Net Credit of the Banking System to General Government 1/

\begin{tabular}{lc}
\hline & (In millions of somoni) \\
\hline December 31, 2004 (indicative target) & -218 \\
March 31, 2005 (performance criterion) & -231 \\
June 30, 2005 (indicative target) & -209 \\
September 30, 2005 (performance criterion) & -169 \\
December 31, 2005 (indicative target) & -178 \\
\hline
\end{tabular}

$1 /$ Calculated at fixed program exchange rate.

\section{Adjustors}

7. Net credit of the banking system to general government will be adjusted downward/upward by 100 percent for excesses/shortfalls of the disbursement of foreign program loans and grants.

\section{E. Net International Reserves}

Table 5. Floor under the Stock of Net International Reserves of the NBT

\begin{tabular}{lc}
\hline & (In millions of U.S. dollars) \\
\hline December 31, 2004 (indicative target) & 67 \\
March 31, 2005 (performance criterion) & 64 \\
June 30, 2005 (indicative target) & 64 \\
September 30, 2005 (performance criterion) & 59 \\
December 31, 2005 (indicative target) & 71 \\
\hline
\end{tabular}

\section{Definitions}

8. Total net international reserves of the NBT are defined as the difference between total gross international reserves of the NBT and total reserve liabilities of the NBT. Total gross international reserves of the NBT are defined to include NBT's holdings of monetary gold, SDRs, convertible currencies in cash or in nonresident banks that are readily available and any reserve position in the IMF. Also included are holdings of foreign currencydenominated securities issued by governments or central banks of OECD member states. Capital subscriptions in foreign financial institutions, nonliquid assets of the NBT, convertible currency denominated claims on domestic banks and other residents, assets in nonconvertible currencies, foreign assets pledged as collateral or otherwise encumbered and the net forward position, if any (defined as the difference between the face value of foreign currency denominated NBT off balance sheet claims on nonresidents and foreign currency 
obligations to both residents and nonresidents) are excluded. Reserve liabilities of the NBT are defined as the sum of outstanding IMF credit, and liabilities of the NBT to nonresidents with an original maturity of up to and including one year.

9. Fund staff will be informed of details of any gold sales, purchases, or swap operations during the program period, and any resulting changes in the level of gross foreign reserves that arise from revaluation of gold will be excluded from gross reserves (as defined above).

\section{Adjustors}

10. The floor on net international reserves of the NBT will be adjusted upward/downward by 100 percent for excesses/shortfalls of the disbursement of foreign program loans and grants.

\section{F. Limits on Short-, Medium-, and Long-Term External Debt}

Table 6. Cumulative Ceiling on the Contracting or Guaranteeing of Nonconcessional External Debt

\begin{tabular}{lcc}
\hline & $0-1$ Year Maturity & Over 1 Year Maturity \\
\hline During the period from end-September 2004 to: & & \\
December 31, 2004 (indicative target) & 0 & 0 \\
March 31, 2005 (performance criterion) & 0 & 0 \\
June 30, 2005 (indicative target) & 0 & 0 \\
September 30, 2005 (performance criterion) & 0 & 0 \\
December 31, 2005 (indicative target) & 0 & 0 \\
\hline
\end{tabular}

\section{Definitions}

11. The external debt limits (short, medium, and long term) apply to the government of Tajikistan, the National Bank of Tajikistan and any other agency acting on behalf of the government. For short, medium- and long-term external debt, the performance criterion applies not only to debt as defined in point No. 9 of the Guidelines on Performance Criteria with Respect to Foreign Debt (Decision No. 12274-(00/85), adopted August 24, 2000), but also to commitments contracted or guaranteed and for which value has not been received.

12. The definition of debt set forth in point No. 9 of the guidelines reads as follows:

"(a) For the purposes of this guideline, the term "debt" will be understood to mean a current, i.e., not contingent, liability, created under a contractual arrangement through the provision of value in the form of assets (including currency) or services, and which requires the obligor to make one or more payments in the form of assets (including currency) or services, at some future points in time; these payments will discharge the principal and/or interest liabilities under the contract. Debts can take a number of forms, the primary ones being as follows:

(a) loans, i.e., advances of money to obligor by the lender made on the basis of an 
undertaking that the obligor will repay the funds in the future (including deposits, bonds, debentures, commercial loans, and buyers' credits) and temporary exchanges of assets that are equivalent to fully collateralized loans under which the obligor is required to repay the funds and usually pay interest, by repurchasing the collateral from the buyer in the future (such as repurchase agreements and official swap arrangements); (b) suppliers' credits, i.e., contracts where the supplier permits the obligor to defer payments until some time after the date on which the goods are delivered or services are provided; and (c) leases, i.e., arrangements under which property is provided which the lessee has the right to use one or more specified period(s) of time that are usually shorter than the total expected service life of the property, while the lessor retains the title to the property. For the purpose of the guideline, the debt is the present value (at the inception of the lease) of all lease payments expected to be made during the period of the agreement excluding those payments that cover the operation, repair or maintenance of the property. (b) Under the definition of debt set out in point 9(a) above, arrears, penalties, and judicially awarded damages arising from the failure to make payment under a contractual obligation that constitutes debt are debt. Failure to make payment on an obligation that is not considered debt under this definition (e.g., payment on delivery) will not give rise to debt."

13. External debt limits apply to the contracting or guaranteeing of new nonconcessional short term external debt (with an original maturity of up to and including one year), and to the contracting or guaranteeing of new nonconcessional medium- and long-term external debt (with original maturities of more than one year).

14. Excluded from the external debt limits are loans contracted for the purpose of debt rescheduling or refinancing if the terms of the new loan are more favorable. IMF credit is excluded from the external debt limits. The performance criterion on new nonconcessional short-term external debt will not apply to loans classified as international reserve liabilities of the NBT (liabilities of the NBT to nonresidents with an original maturity of up to and including one year). Normal import-related financing is excluded from the performance criterion on new short-term external debt.

15. Debt falling within the external debt limits that are denominated in currencies other than the U.S. dollar shall be valued in U.S. dollars at the exchange rate prevailing at the time the contracting or guaranteeing takes place or at the exchange rate stipulated in the contract.

16. For the purposes of the program, the guarantee of a debt arises from any explicit legal obligation of the government or the NBT or any other agency acting on behalf of the government to service such a debt in the event of nonpayment by the debtor (involving payments in cash or in kind), or indirectly through any other obligation of the government or the NBT or any other agency acting on behalf of the government to finance a shortfall incurred by the debtors.

17. A concessional debt is defined as one with a grant element equivalent to 35 percent or more. The grant element is calculated using the commercial interest reference rates (CIRRs) plus a margin, which will be taken as those for January 1, 2005 until this is revised in the 
program. For debts of an original maturity of 15 years or more, the average CIRR over the last 10 years will be used, while the average of CIRRs of the preceding six-month period will be used to assess the concessionality of debts with original maturities of less than 15 years. To the ten-year and six month averages of CIRRs, the following margins will be added: 0.75 percent for repayment periods of less than 15 years; 1 percent for 15-19 years; 1.15 percent for 20-29 years; and 1.25 percent for 30 and more years. In general, grant element is calculated as value of the loan minus present discounted value of future payments over the loan value (multiplied by 100). Present discounted value is sum of all future discounted payments (both amortization and interest), where the discount rate corresponds to the above commercial interest reference rate.

\section{Continuous Quantitative Targets}

\section{A. No Directed Credits by the NBT}

18. The NBT will not issue any directed credits. These involve credits that are issued in the absence of a competitive auction or on nonmarket terms and conditions. This requirement will be monitored on the basis of changes in the NBT's balance sheets supported by the NBT's regular reporting on credit related activities.

\section{B. No Noncore Activities of the NBT and no Dividend Payments by the NBT}

19. The NBT will neither make any expenditures not related to its core business activities nor pay dividends while it has negative net worth.

\section{No New External Payments Arrears}

20. No new external payments arrears shall be accumulated at any time under the PRGF arrangement, excluding those which are subject to negotiation among creditors. External payments arrears are defined as debt service overdue for 30 days or more arising in respect of obligations incurred directly, guaranteed, or converted into interstate debt by the government of Tajikistan or the NBT, including penalties or interest charges.

\section{Ceiling on General Government Wage and Nonworking Pensioners Pension Arrears}

21. For purposes of the performance criterion, arrears on general government and nonworking pensioner' pension shall be monitored as any shortfall in monthly disbursements of wages and pensions. The monthly disbursement plan will be a third of each quarter's budgeted wage and pension payments as in the general government budget and budget of the Social Protection Fund. These payments are defined as overdue if they have come due at the end of the month and remain unpaid thereafter for 30 days or more. The program ceilings on the stock of wage and pension arrears are presented in Table 7 below: 
Table 7. Stock of Wage and Pension Arrears

\begin{tabular}{lc}
\hline & (In millions of somoni) \\
\hline Cumulative from October 1, 2004 to: & \\
December 31, 2004 (indicative target) & 0 \\
March 31, 2005 (performance criterion) & 0 \\
June 30, 2005 (indicative target) & 0 \\
September 30, 2005 (performance criterion) & \\
Cumulative from October 1, 2005 to: & \\
December 31, 2005 (indicative target) & 0 \\
\hline
\end{tabular}

22. To permit monitoring as defined above, the government will provide data on actual wage payments (as part of the monthly budget execution statements submitted to Fund staff). The Social Protection Fund will provide quarterly reports and statements of their operations.

\section{Indicative QUANTITATIVE TARGETS}

\section{A. Reserve Money}

Table 8. Indicative Ceiling on the Stock of Reserve Money

\begin{tabular}{lc}
\hline & (In millions of somoni) \\
\hline December 31, 2004 & 278 \\
March 31, 2005 & 252 \\
June 30, 2005 & 257 \\
September 30, 2005 & 278 \\
December 31, 2005 & 305 \\
\hline
\end{tabular}

\section{Definition}

23. The stock of reserve money is defined as the sum of: (a) domestic currency issued by the NBT; (b) deposits of commercial banks and other financial institutions held with the NBT; and (c) deposit liabilities of the NBT with respect to the public. NBT reserve money liabilities with respect to commercial banks and other financial institutions comprise all deposits held by these institutions at the NBT, including required reserves and excess reserves held in the correspondent accounts, but excluding NBT liabilities held by commercial banks and other financial institutions in the form of short term NBT notes. Deposit liabilities of the NBT to the public include all deposits placed at the NBT, in domestic or foreign currency, by the nonbank public. 


\section{B. New Arrears of Budget Entities and State-Owned Enterprises to Naftrason, Barqui Tajik and Tajikgas}

Table 9. Indicative Ceiling on New Arrears of Budget-Entities and Key State-Owned Enterprises to Barqui Tajik, Naftrason, and Tajikgas

\begin{tabular}{lc}
\hline & (In millions of somoni) \\
\hline December 31, 2004 & 0 \\
March 31, 2005 & 0 \\
June 30, 2005 & 0 \\
September 30, 2005 & 0 \\
December 31, 2005 & 0 \\
\hline
\end{tabular}

\section{Definition}

24. Budget entities include all entities that are included in the state budget law. Key stateowned enterprises are Tadaz, Nitrogen (Sarband city), and Tajikcement.

\section{Reporting ReQuirements Under the Program}

25. For monitoring program targets, the following data should be reported to the Fund.

Table 10. Data reporting frequency for program monitoring

\begin{tabular}{|c|c|c|}
\hline Data & Frequency & Lag \\
\hline 1. NBT analytical balance sheet & Weekly & 3 working days \\
\hline 2. NBT balance sheet & Monthly & 2 weeks \\
\hline 3. Commercial banks' and Kredit Invest balance sheets & Monthly & 4 weeks \\
\hline 4. Auction results for NBT certificates and treasury bills & Weekly & 1 week \\
\hline 5. Foreign exchange transactions & Weekly & 1 week \\
\hline $\begin{array}{l}\text { 6. Fiscal revenues, expenditures and financing } \\
\text { of budget execution, and extrabudgetary funds }\end{array}$ & Monthly & 4 weeks \\
\hline $\begin{array}{l}\text { 7. Reports and statements from the Social } \\
\text { Protection Fund }\end{array}$ & Quarterly & 6 weeks \\
\hline $\begin{array}{l}\text { 8. Arrears of budget entities and state owned } \\
\text { enterprises }\end{array}$ & Quarterly & 4 weeks \\
\hline 9. Tax arrears of the largest tax payers in arrears & Quarterly & 4 weeks \\
\hline $\begin{array}{l}\text { 10. Stock of disbursements and comittments of external debt, } \\
\text { with details of principle, interest rate, maturity, grace period. } \\
\text { and amortization. }\end{array}$ & Quarterly & 4 weeks \\
\hline
\end{tabular}


INTERNATIONAL MONETARY FUND

REPUBLIC OF TAJIKISTAN

\title{
Fifth Review Under the Poverty Reduction and Growth Facility and Request for Waiver of Performance Criterion Supplementary Information
}

\author{
Prepared by the Middle East and Central Asia Department \\ (In consultation with other departments) \\ Approved by Juan Carlos Di Tata and Mark Plant
}

July 15,2005

1. This supplement provides an update on recent economic developments and the implementation of structural measures since the staff report for the fifth review under the PRGF arrangement was issued. It does not change the thrust of the staff appraisal.

2. Economic conditions remain broadly as described in the staff report. Preliminary data indicate that real GDP grew by 8 percent in the first half of 2005, in line with program projections. Headline inflation (12-month basis) rose slightly to 8.8 percent in June 2005, on account of higher transportation costs and electricity prices (see below) and a small depreciation of the somoni.

3. Continued prudent fiscal and monetary policies have kept the financial program on track. Preliminary data indicate that the end-June 2005 indicative targets for the net domestic assets of the National Bank of Tajikistan (NBT), net credit of the banking system to the government, net international reserves, and reserve money were observed. A large buildup in government deposits at the NBT appears to be related to a robust revenue performance in June. Net international reserves were \$10 million above the end-June program target of $\$ 64$ million. 
Monetary Performance, end-June 2005

(In millions of somoni; unless otherwise indicated)

\begin{tabular}{|c|c|c|c|}
\hline & $\begin{array}{l}\text { Indicative } \\
\text { targets }\end{array}$ & $\begin{array}{c}\text { Indicative } \\
\text { targets (adj.) 1/ }\end{array}$ & Prel. \\
\hline Ceiling on net domestic assets of the NBT & 82 & 64 & 32 \\
\hline Ceiling on net credit of the banking system to government & -196 & -214 & -285 \\
\hline Floor on net international reserves (millions of U.S. dollars) & 58 & 64 & 74 \\
\hline Reserve money (indicative target) & 257 & 257 & 257 \\
\hline
\end{tabular}

Sources: National Bank of Tajikistan; and Fund staff estimates.

1/ Adjusted for the unanticipated disbursement of a loan from the Asian Development Bank ( $\$ 5.8$ million).

\section{Recent structural actions (Box 1) were:}

- $\quad$ On July 2, the strategic planning functions of the presidential administration and the Ministry of Economy and Trade were rationalized, in line with the March 2005 structural benchmark. As part of ongoing reforms in this area, the new national development strategy will provide for greater participation of the civil society, and will seek to better integrate the country's growth objectives with poverty reduction, the MDGs, and development assistance. This new approach is being supported by the UNDP and the Millennium Project.

- $\quad$ NBT debt recoveries through early July remained at SM 4 million. The expected realization of the collateral provided for one loan could yield a further SM 5 million in the third quarter, if approved by the State Property Committee.

- In June, additional companies were added to the large taxpayer inspectorate (LTI), including mobile phone operators and the branches of banks that previously were not included in the LTI. This brought the coverage of the LTI to 61 percent of tax collections.

- $\quad$ The database for private external debt became operational in early July. Preliminary information indicates that the private external debt amounts to \$226 million and is mainly related to the financing of the cotton sector. The data are being reviewed in the context of the strategy for the resolution of the cotton sector debt.

- In June, electricity tariffs for households were doubled to about the same level applied in winter. This step is expected to encourage greater involvement of foreign investors, the World Bank Group, and other multilateral lenders in the rehabilitation of the electricity sector. 
- $\quad$ On July 4, the NBT started to adjust the official exchange rate on a daily basis using the weighted average exchange rate for all bank transactions. As a result, the differential between the official exchange rate and the exchange rate in the cash market has been virtually eliminated. 


\section{Box 1. Tajikistan: Performance Under the Third Annual Program Under the PRGF Arrangement, May-July 2005}

Measure

Status

(as of July 12, 2005)

Indicative targets (June 2005)

Ceiling on net domestic assets of the NBT.

Ceiling on net credit of the banking system to general government.

Ceiling on the cumulative overall fiscal balance of the general government.

Ceiling on general government wage and nonworking pensioners' pension arrears

Floor on tax collection of the ministry of state revenues and duties.

Floor on net international reserves.

Ceiling on the contracting or guaranteeing of short-, medium-, and long-term nonconcessional external debt.

New external payments arrears (continuous quantitative performance criterion).

Ceiling on reserve money.

New arrears of budget entities and key state-owned enterprises to utility companies.

Continuous structural performance criteria (through end May 2005)

Prohibit the NBT from issuing directed credits.

Prohibit the NBT from making expenditures not related to its core business.

Implement quarterly adjustments of all utility tariffs, equivalent to the depreciation in the nominal exchange rate in the previous quarter.

\section{Structural benchmarks}

For end-March 2005

Implement the mechanism to ensure the immediate transfer to the Treasury by

Barki Tajik of the tax portion of TADAZ's payments to Barki Tajik.

As part of streamlining economic ministries, cease publication of detailed production targets disaggregated below the national level. Integrate various bodies preparing strategic plans and coordinating aid.

\section{For end-June 2005}

Reduce NBT's claims on the private sector by SM 10 million from October 2004 to June 2005 through collateral sales or other loan recoveries.

Remove the regulatory limits on foreign capital in the banking system and the requirement in the Banking Law that Tajik citizens to head commercial banks.

Expand the register of the Large Taxpayer Inspectorate (LTI) to cover at least 60 percent of total tax collections.

Develop and continuously update a database at the NBT for monitoring private sector external debt (starting with cotton sector debt).
Observed

Observed

Data not yet available

Data not yet available

Data not yet available

Observed

Data not yet available

Data not yet available

Observed

Data not yet available

Observed

Observed

Observed

Observed in April

Observed in July

SM 4 million collected by early July, remainder pending approval of sale of collateral

Amendments submitted to parliament in early July

Observed

Observed in early July 
September 26, 2005

\section{IMF Executive Board Completes Fifth Review Under the Republic of Tajikistan's PRGF Arrangement and Approves US\$14.3 million Disbursement}

The Executive Board of the International Monetary Fund (IMF) has completed the fifth review of the Republic of Tajikistan's performance under its economic reform program supported by a three-year Poverty Reduction and Growth Facility (PRGF) arrangement. Completion of the review was on a lapse of time basis on July 18, 2005 and enabled the Republic of Tajikistan to draw an amount equivalent to SDR 9.8 million (about US\$14.3 million) under the arrangement.

The IMF's Executive Board approved the three-year arrangement on December 11, 2002 (see Press Release No. 02/54) for an amount equivalent to SDR 65 million (about US\$95.2 million). Drawing the amount made available by completion of this fifth review brought total disbursements under the arrangement to SDR 55.2 million (about US\$80.8 million).

The PRGF is the IMF's concessional facility for low-income countries. PRGF-supported programs are based on country-owned poverty reduction strategies adopted in a participatory process involving civil society and development partners and articulated in the Poverty Reduction Strategy Paper (PRSP). This is intended to ensure that PRGF-supported programs are consistent with a comprehensive framework for macroeconomic, structural, and social policies to foster growth and reduce poverty. PRGF loans carry an annual interest rate of 0.5 percent and are repayable over 10 years with a $5 \frac{1}{2}$-year grace period on principal payments. 